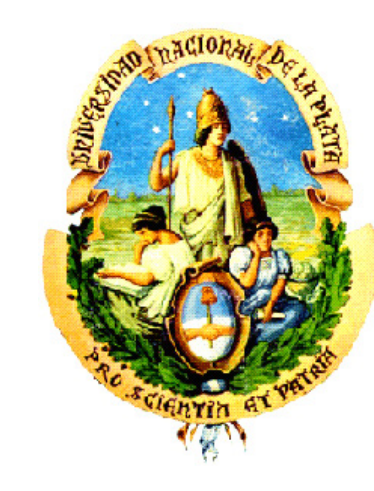

\title{
FACULTAD DE ODONTOLOGÍA
}

\author{
UNIVERSIDAD NACIONAL DE LA PLATA
}

\section{MAGISTER EN IMPLANTOLOGIA ORAL TESIS DE MAGISTER}

TÍTULO: CARACTERIZACIÓN NANOMÉTRICA DE SUPERFICIES LISAS, ÁCIDO GRABADAS Y ANODIZADAS DE TITANIO MEDIANTE MICROSCOPÍA DE FUERZA ATÓMICA (AFM) PARA APLICACIÓN EN IMPLANTOLOGÍA ODONTOLÓGICA

AUTOR: Od. Costantino, Alejandro

DIRECTORA: Prof. Dra Maria Cecilia Cortizo

AÑO: 2015 


\section{RESUMEN}

Los dientes perdidos y sus reemplazos han significado un desafío durante toda la historia humana, con lo que la investigación llevó a desarrollar modelos con cambios continuos importantes no solo en los protocolos quirúrgicos y protésicos sino también en el mismo diseño de los dispositivos. El diseño de los implantes refiere su estructura tridimensional con todos los elementos y características que la componen: forma, configuración, macroestructura superficial y macroirregularidades. Se ha afirmado que la calidad del implante dental depende de las características químicas, físicas, mecánicas y topográficas de su superficie. Estas diferentes propiedades interactúan y determinan la actividad de las células que se encuentran próximas a la superficie del implante. El uso de superficies rugosas a un nivel nanométrico es de aparición reciente e involucra rangos dimensionales entre 1 y $100 \mathrm{~nm}$, escala que juega un papel importante en la osteointegración: la superficie texturizada aumenta la energía superficial y con ello la mojabilidad a la sangre y la adhesión celular, y facilita el depósito de fibrina, factores de crecimiento y matriz proteica. Entendiendo que la Microscopía de Fuerza Atómica (AFM) ofrece tecnología actual de alta sensibilidad para el análisis de nanoestructuras y para establecer rangos de eventuales aplicaciones clínicas en odontología implantológica, se propone aplicarla sobre diferentes tratamientos de superficie en titanio para caracterizarlos nanométricamente y con ello poder elaborar un modelo teórico para ulteriores investigaciones de aplicación clínica sustentadas en las bases biológicas establecidas por la bibliografía. 


\section{INDICE GENERAL}

Capítulo 1. Introducción, estado del arte y fundamentación 7

1.1. Introducción 7

1.2. Estado del arte y fundamentación de la investigación 10

Capítulo 2. Marco teórico 17

2.1. Los implantes dentales 17

2.1.1. Definición y clasificación 17

2.2. Bases anatómicas de los implantes dentales 23

2.2.1. El hueso 23

2.2.2. La mandíbula y el maxilar 28

2.2.3. Configuración del proceso alveolar maxilar 32

2.2.4. Los ejes dentarios del maxilar 33

2.2.5. Estructura de la pared alveolar maxilar 34

2.2.6. Ejes dentarios de la mandíbula 35

2.2.7. Estructura de la pared alveolar mandibular 35 
2.2.9. Irrigación de los dientes y la encía 38

2.2.10. Restricciones fisiológicas de la implantología en el hueso 39

2.3. La osteointegración y la implantología dentaria 40

2.3.1. La osteointegración 40

2.3.2. Factores que influyen en la osteointegración 42

1. El material del implante 43

2. La calidad superficial del implante 46

3. El diseño macroscópico y dimensional del implante 48

4. El estado del hueso del receptor 49

5. La técnica quirúrgica empleada 49

6. Las condiciones de carga del implante 51

2.3.3. Reacciones histológicas en tejidos óseos 52

2.3.4. La osteointegración y las superficies del implante 54

A. Superficies lisas y rugosas 58

B. Tratamiento de las superficies 62

C. Técnicas para medir la rugosidad 66 
5.1.1. Preparación de las placas de titanio y modificación de sus superficies 76

5.1.2. Análisis de superficie topográfica 82

5.1.3. Procesamiento de imágenes topográficas 83

5.2. Análisis estadístico de los datos 85

Capítulo 6. Resultados 86 


\section{- Capítulo 1: Introducción, estado del arte y fundamentación}

- Introducción

La historia de la salud dental ha sido guiada, como la de tantas otras disciplinas terapéuticas, por diversos avances tecnológicos, que han posibilitado ampliamente su desarrollo y perfeccionamiento desde diversos puntos de vista. No cabe lugar a dudas que, desde su aparición, los implantes dentales han supuesto un enorme avance en lo que refiere al terreno rehabilitador de la odontoestomatología, llegando a ocupar un lugar fundamental siendo una alternativa altamente válida y efectiva a largo plazo en lo que respecta al tratamiento del edentulismo parcial o total.

Cabe destacar que dicha efectividad está ligada a la persistencia de la salud de los tejidos blandos y duros periimplantarios y de la adecuada distribución de las fuerzas sobre los implantes en cuestión. Por tanto, para asegurar la durabilidad del implante, resulta necesario considerar dichos puntos.

Asimismo, la biocompatibilidad del material con el que se realiza la implantación resulta esencial para el éxito de la intervención en cuestión. En la actualidad, se considera que el titanio y sus aleaciones operan óptimamente en la mayor parte de los casos cuando se trata de hacer implantaciones dentarias. Se trata, en efecto, de un material bioinerte, dotado de una buena resistencia a la corrosión. Además, se ha demostrado que la cantidad de iones que dicho material libera al medio físico es altamente baja, pues la capa de óxido que se forma en su superficie logra pasivarlo. Por este motivo, el titanio actúa como una 
suerte de intercara cerámica bioinerte, aunque, a diferencia de la cerámica, posibilita un anclaje óptimo en el tejido óseo vecino.

Si bien a partir de la implementación de dicho material en la implantación dental se han detectado resultados clínicos excelentes a largo plazo en la rehabilitación odontológica total o parcial, diversos estudios han intentado, a lo largo de la historia de los implantes dentales de titanio, perfeccionar al máximo los métodos de implantación, en pos de optimizar los resultados en cuestión.

Los implantes de superficie lisa y diseño atornillado, presentados en sus inicios por el sistema Branernark, caracterizados por el empleo de titanio puro o de aleaciones de dicho material, han logrado, desde los años sesenta del pasado siglo, respuestas biológicas de osteointegración harto exitosas. Sin embargo, tal como se viene sugiriendo, estudios acerca de la osteointegración de los implantes endoóseos, han establecido la inminente posibilidad de mejorar la respuesta ósea en el entorno de la zona implantada mediante la modificación de la superficie y la modulación de respuesta celular y molecular. Se ha determinado, además, mediante una serie de estudios histológicos, que los implantes cuya superficie presenta una textura rugosa, presentan respuestas óseas mejoradas y un incremento en el área de contacto superficial hueso-implante con la textura en cuestión.

Sin embargo, no existen suficientes estudios clínicos a dicho respecto, por lo que resulta difícil sostener dicha postura. Es necesario, por tanto, indagar, mediante investigaciones de carácter empírico, acerca de cómo los cambios producidos en la rugosidad de la superficie de los implantes pueden ser o no favorables en lo que respecta la efectividad de los mismos. 
Cabe destacar que, en la actualidad, existen diversos métodos, gracias al desarrollo exhaustivo de la nanotecnología, capaces de dar cuenta de los cambios superficiales y del modo en que estos afectan el éxito de la implantación. Las mediciones efectuadas mediante dichas técnicas deberían ser capaces de intervenir en la mejora de la preparación de las superficies de los implantes. No hay lugar a dudas acerca de que dicha preparación debe ser llevada a cabo con gran cuidado, teniendo en cuenta las necesidades terapéuticas de cada paciente, de acuerdo a sus caracteres fisiológicos y el tipo de patología odontológica. Sólo así se podrá garantizar el éxito de la intervención [1].

El presente trabajo se centra en la llamada Microscopía de Fuerza Atómica, una técnica nanométrica capaz de dar cuenta con gran precisión de los diferentes cambios que implican a las superficies de los implantes. Para ello se revisará, en el Capítulo 2, la noción de implantación dentaria de acuerdo a diferentes perspectivas. También en dicho capítulo, se dará cuenta de las principales técnicas nanométricas conocidas hasta el momento y de su aplicación en el campo de la odontología, ubicando a la Microscopía de Fuerza Atómica en un lugar central del desarrollo.

En el Capítulo 3 se expondrá la hipótesis y los objetivos del trabajo experimental realizado, orientado a caracterizar, mediante la Microscopía de Fuerza Atómica, las diferentes rugosidades implicadas en los tratamientos de superficie de titanio. El capítulo 4 y 5 expondrán el diseño de dicha investigación de manera detallada y los materiales y métodos utilizados en la misma.

Los resultados de la misma se exhibirán en el Capítulo 6. A partir de éste y de su confrontación con las bases teóricas expuestas en el Capítulo 2, será posible sacar una serie de conclusiones. Las mismas serán expuestas en el Capítulo 7. 
- Estado del arte y fundamentación de la investigación

Los dientes perdidos y sus reemplazos han significado un desafío durante toda la historia humana. Sin embargo, no sería sino hasta mediados de los años 60 cuando se fundarían las bases de la moderna odontología implantológica [1]. Hasta ese momento, los implantes orales eran utilizados en muy pequeño número, con diseños de dispositivos subperiósticos, laminados o transmandibulares, todos documentados de manera inadecuada y en general con pobres resultados clínicos. En 1965, Branemark colocó su primer implante oral, y en los siguientes 5 años sus resultados parecieron continuar esta tendencia deslucida. Todo aparentaba confirmar que materiales extraños al organismo no trabajaban en buena concordancia con los tejidos orales por diferentes razones, entre ellas el riesgo de infección [2].

Sin embargo, la investigación llevó a desarrollar nuevos modelos con cambios importantes no solo en los protocolos quirúrgicos y protésicos sino también en el mismo diseño de los dispositivos. Si bien la disputa y controversia continuaría hasta muchos años después (recién en 1985 sería aceptado el fenómeno de "osteointegración) [2], sin dudas la revolución iniciada por Branemark y col. radicó principalmente en el uso del titanio como material de implantación (reemplazando a otros metales y aleaciones por su excepcional biocompatibilidad y resistencia a la corrosión) [1, 3], y en el maquinado de su superficie para favorecer su integración al hueso (de hecho, en su publicación original pueden encontrarse implantes con conexiones internas y externas, diferentes morfologías en sus bordes, muescas, espiras y superficies y variaciones en sus dimensiones relativas) [4]. En la actualidad, los implantes intraóseos conforman una modalidad terapéutica corrientemente aceptada y recomendada para la reconstrucción oral y craneofacial [1], cuyos cambios en los protocolos implantológicos han sido atribuidos al mejoramiento de los procedimientos quirúrgicos, al entendimiento biomecánico, a las modificaciones del diseño del dispositivo y al 
desarrollo de nuevos tratamientos superficiales para obtener una respuesta biológica óptima [5].

El diseño de los implantes refiere su estructura tridimensional con todos los elementos y características que la componen: forma, configuración, macroestructura superficial y macroirregularidades [1]. Se ha referido que la superficie implantaria configura uno de los seis factores descritos por Albrektsson et al. influyendo en la reparación del sitio de implantación y la consecuente osteointegración [6]: la topografía superficial guía y favorece el movimiento de células específicas afectando directamente su forma y función [5], el tratamiento ácido de la superficie mejora la resistencia al torque [1], la presencia de poros con profundidades entre 150 y $300 \mu \mathrm{m}$ favorece el crecimiento y contacto óseo e índices de éxito cercanos al $95 \%$ a los 4 años [1]. Más recientemente, la "Anodización”, proceso electrolítico de pasivación donde el implante hace de ánodo en un circuito eléctrico, origina una superficie microporosa $(0,5-3 \mu \mathrm{m})$ que logra acelerar los procesos de reparativos en el sitio de implantación [5].

La calidad del implante dental depende de las características químicas, físicas, mecánicas y topográficas de su superficie. Estas diferentes propiedades interactúan y determinan la actividad de las células que se encuentran próximas a la superficie del implante [6]. Se ha reconocido que entre los factores de mayor influencia se encuentra la denominada mojabilidad (término que define la capacidad de una superficie de adherir un elemento fluido), propiedad que depende de la energía superficial y la influencia del grado de contacto con el entorno fisiológico [6], lo que determina un comportamiento celular de mayor dinámica de absorción de las biomoléculas a la superficie implantaria [3]. Diferentes evaluaciones han demostrado que los implantes de superficies rugosas muestran mejor aposición y relación implante-hueso que los de superficies lisas [6]. Se ha concluido así que las superficies con microestructuras definidas aumentan la estabilidad del anclaje, influyen positivamente en la reacción celular, en el control de las reacciones que 
conducen a la osteointegración y a una óptima performance implantológica [5].

La química superficial involucra adhesión de proteínas, bacterias y células sobre los implantes; la mojabilidad y la energía superficial influyen en la absorción de proteínas e incrementan la adhesión de osteoblastos sobre la superficie implantaria. La conducta celular sobre superficies hidrofílicas es completamente diferente que sobre las hidrofóbicas: una superficie hidrofílica mejora la coagulación sanguínea en relación a una hidrofóbica; las expresiones de los factores de diferenciación ósea específica para los osteoblastos es mayor en las hidrofílicas. En consecuencia, los fabricantes de implantes dentales han desarrollado superficies de alta hidrofilicidad y rugosidad con lo que se ha observado una mejor osteointegración que en los implantes lisos [6].

La rugosidad superficial implantaria puede ser categorizada en macro, micro y nano rugosidad [3]. La macrorugosidad se compone de patrones en el rango del milímetro a décimas de micrones. Esta escala se relaciona directamente con la geometría del implante, la rosca del tornillo y los tratamientos de superficie macro porosa. La fijación primaria del implante y su estabilidad mecánica a largo plazo pueden ser potenciadas con una apropiada macro rugosidad. La microrugosidad, por otro lado, es definida en el rango de 1-10 $\mu \mathrm{m}$, el que maximiza el "engranaje" entre el hueso mineralizado y la superficie implantaria. El uso de superficies provistas con topografías nanométricas es de aparición reciente e involucra materiales con un rango dimensional entre 1 y $100 \mathrm{~nm}$. Esta escala de rugosidades juega un papel importante en la osteointegración: la superficie texturizada aumenta la energía superficial y con ello la mojabilidad a la sangre y la adhesión celular, y facilita el depósito de fibrina, factores de crecimiento y matriz proteica $[3,6,7]$.

Los métodos empleados para la modificación superficial de los implantes pueden ser divididos en mecánicos, químicos y físicos, todos destinados a optimizar sus propiedades biomecánicas, estimular la formación ósea, la remoción de contaminantes y aumentar su resistencia al desgaste y la corrosión [6]. Los mecánicos incluyen texturización, 
granallado, maquinado y pulido; los químicos involucran el tratamiento superficial con álcalis (hidróxido de sodio o potasio), ácidos (más comúnmente clorhídrico, fluorhídrico y nítrico), peróxido de hidrógeno (lo que resulta en una dilución química y oxidación del titanio superficial, más favorable para el depósito de apatita), sol-gel (con el consecuente depósito de hidroxiapatita), depósitos de vapor químico (reacción entre químicos en su faz gaseosa y la superficie del sustrato), y la mencionada anodización [3,6]. Los físicos incluyen al plasma spray y al bombardeo iónico, los que favorecerían la formación de capas de titanio y fosfato cálcico superficial, mejorando con ello la biocompatibilidad, la actividad biológica y la resistencia al desgaste y la corrosión [6]. La ablación láser, tecnología para la preparación superficial utilizada en numerosas aplicaciones industriales, resulta además útil en los implantes dentales pues resulta en la formación de micro estructuras con un exponencial aumento de la dureza, resistencia a la corrosión y mejoramiento de su pureza [6]. También han sido reportados diferentes agregados de fármacos y sustancias bioactivas para mejorar y acelerar la osteointegración tales como bifosfonatos (con relevantes pérdidas en los huesos de soporte), estatinas, antibióticos (gentamicinas, tetraciclinas), proteínas óseas morfogenéticas, factores de crecimiento y plasma rico en plaquetas, todos con diferentes resultados [6].

La enorme variedad y constante evolución en el diseño de los implantes, derivado de hallazgos científicos e investigación, refleja los intentos de los investigadores de vincular exitosamente una estructura artificial dentro de un sistema biológico. Es evidente que los implantes deben ser cuidadosamente seleccionados, balanceando las propiedades surgidas de la investigación con la planificación terapéutica estimada [1]. Arismendi et al. (2004) refieren que "existe una gran confusión en la literatura cuando se habla de las características superficiales de los implantes". En general, se han establecido las categorías de superficies "rugosas" y "pulidas" o "maquinadas". Resulta que las superficies "pulidas" no son tan lisas como aparentan y las superficies "rugosas" varían considerablemente entre sí. También existe la costumbre de definir 
la superficie por su proceso de fabricación (arenado, plasma de titanio, grabado ácido) lo cual no provee ninguna definición clara del tipo de superficie que permita una comparación entre los diferentes grupos de implantes" [7]. Las metodologías utilizadas para preparar las superficies de los implantes comercialmente disponibles son mayormente empíricas, requiriendo un gran número de ensayos; sus pruebas no están estandarizadas lo que hace difícil comparar sus resultados [5]. De igual modo, existe un gran número de técnicas de medición bi y tridimensionales disponibles para caracterizar la topografía superficial, todas ellas con limitaciones en los planos horizontales y verticales [7].

Se ha propuesto a la Microscopía de Fuerza Atómica (AFM, Atomic Force Microscope) como una metodología de mayor precisión para la detección de cambios superficiales en los implantes de titanio a un nivel nanométrico [8]. AFM permite la resolución de átomos individuales tanto de superficies conductoras como aislantes, y ha demostrado ser de fracciones de nanómetro, más de 1000 veces mejor que el límite de difracción óptica, y es una de las principales herramientas para generar imágenes y medir propiedades a escala nanométrica. El término "microscopio" utilizado para este equipo se encuentra mal empleado, pues implica observación cuando en realidad la información es recopilada "sintiendo" la superficie con una sonda mecánica $[9,10]$.

El AFM consiste en una sonda en cantiliver de tamaño microscópico, con una punta fina en el extremo que es utilizada para barrer la superficie de la muestra. La sonda está fabricada normalmente de silicio o nitruro de silicio, con un radio de curvatura en la punta del orden de nanómetros. Cuando la punta se aproxima a la superficie de la muestra, las fuerzas entre la punta y la muestra generan una deflexión de la sonda de acuerdo a la ley de Hooke, que establece que la cantidad de deformación que tiene el cuerpo de un material es linealmente proporcional al esfuerzo aplicado sobre éste [10]:

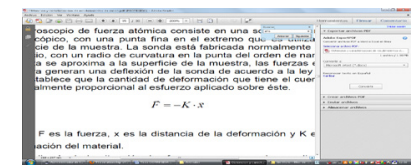


Donde $F$ es la fuerza, $x$ es la distancia de la deformación y $K$ es la constante de deformación del material. Dependiendo de la situación, las fuerzas que se pueden medir en el microscopio de fuerza atómica incluyen la fuerza mecánica de contacto, las fuerzas de Van del Waals, las fuerzas capilares, el enlace químico, fuerzas electroestáticas, fuerzas magnéticas, etc.

Comúnmente, la deflexión se mide utilizando un haz de luz láser que se refleja en la parte superior de la aguja hacia un conjunto de detectores de luz, otros métodos que son usados, interferometría óptica, detección capacitiva o zondas piezo resistivas [10].

En odontología, el estudio de estructuras dentales y materiales desde una perspectiva nanométrica puede conducir a una mejor comprensión de las relaciones entre estructura, función y fisiología. Han sido reportadas extensas aplicaciones de AFM para significar cuantitativamente la topografía y las propiedades mecánicas y bioquímicas de varias superficies biológicas y artificiales de aplicabilidad oral [11].

A manera de ejemplo de la relevancia adquirida por la utilización de caracterizaciones a nanoescala en implantología, Sharma et al. (2010) mencionan al uso de modificaciones de las superficies de los implantes con hidroxiapatita y sus consecuentes efectos respecto a biocompatiblidad y osteointegración. Más allá de la inferencia lógica tanto del diseño como de la implementación del material, las aplicaciones iniciales produjeron resultados fuertemente negativos con altos índices de fracaso que fueron atribuidos a efectos mecánicos. Sin embargo, ulteriores investigaciones utilizando nanoescala han demostrado que la nanotopografía posee la misma importancia que el sustrato químico, con altos niveles de osteointegración tanto in vitro como in vivo y favorable biocompatibilidad. En esos casos, la capacidad para caracterizar cuantitativamente la topografía a nanoescalas ha sido fundamental para dilucidar los mecanismos fisicoquímicos [11]. 
Si bien es cierto, la migración, adhesión y proliferación celular sobre la conexión implantaria, son condiciones fundamentales para iniciar el proceso de regeneración tisular. Las modificaciones de la superficie del dispositivo permiten también optimizar la osteointegración (especialmente en pacientes con calidad ósea debilitada) y reducen significativamente el periodo de cicatrización, potenciando con ello el éxito de la terapia implantológica [6]. Sin embargo, los mecanismos celulares involucrados necesitan aún de mucha investigación, a lo que pueden sumarse las dificultades para analizar individualmente la influencia de cada uno de los parámetros en la superficie [5, 7], todos elementos que hacen necesaria una mayor investigación de cada uno de estos procesos.

Entendiendo que AFM ofrece la posibilidad de ensayar nuevas aplicaciones para la obtención de nanoestructuras [9], permitiendo además establecer rangos de eventuales aplicaciones clínicas en odontología implantológica [11], se propone aplicar esta metodología de análisis de alta sensibilidad sobre diferentes tratamientos de superficie en titanio para caracterizarlos nanométricamente y con ello poder elaborar un modelo teórico para ulteriores investigaciones de aplicación clínica sustentadas en las bases biológicas establecidas por la bibliografía. 


\section{- Capítulo 2: Marco teórico}

- Los implantes dentales

- Definición y clasificación

Se denomina implante dental a aquel material aloplástico que se aplica, mediante prodecimientos de carácter quirúrgico, sobre el reborde residual óseo y que opera como cimiento de la prótesis dental. Los implantes dentales se suelen clasificar de acuerdo a su forma $y / o$ posición. A continuación detallaremos una posible clasificación a partir de la posición de los mismos [12]:

\section{Clasificación en función de su posición:}

Implantes subperiósticos: son aquellos realizados sobre el hueso. Se trata de estructuras hechas a medida y alojadas por debajo del mucoperiostio (Fig. 1)

Implantes transóseos: son aquellos que se realizan a través del hueso. Sólo es posible colocar este tipo de implantes por debajo de la parte frontal de la mandíbula inferior, atravesando el mucoperiostio y el hueso mandibular (Fig. 2)

Implantes endoóseos: son aquellos realizados dentro del hueso. Se colocan sobre una columna vertical de hueso mediante una incisión mucoperiostial, ya sea en la mandíbula inferior como en la superior (Fig, $3)$. 
Implantes yuxtaóseos: son los implantes realizados al lado del hueso. Cabe destacar que este tipo de implantes suele provocar un colapso vascular en el hueso, por lo que no se emplea con frecuencia por los odontólogos.
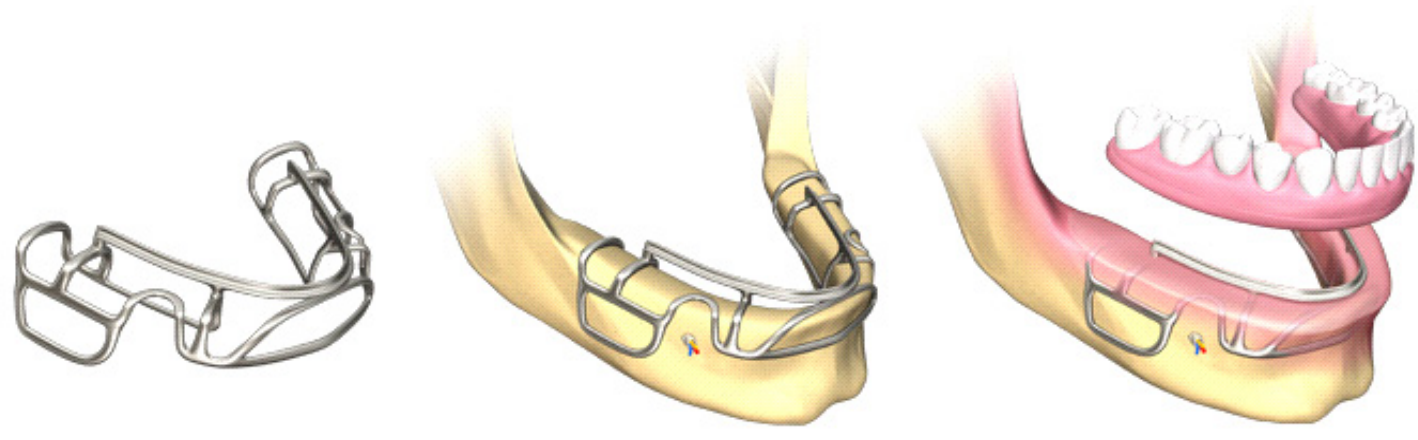

Fig. 1. Implante dental subperióstico

(Fuente: http://www.1888implant.com/spanish/dental-implants.html\#)
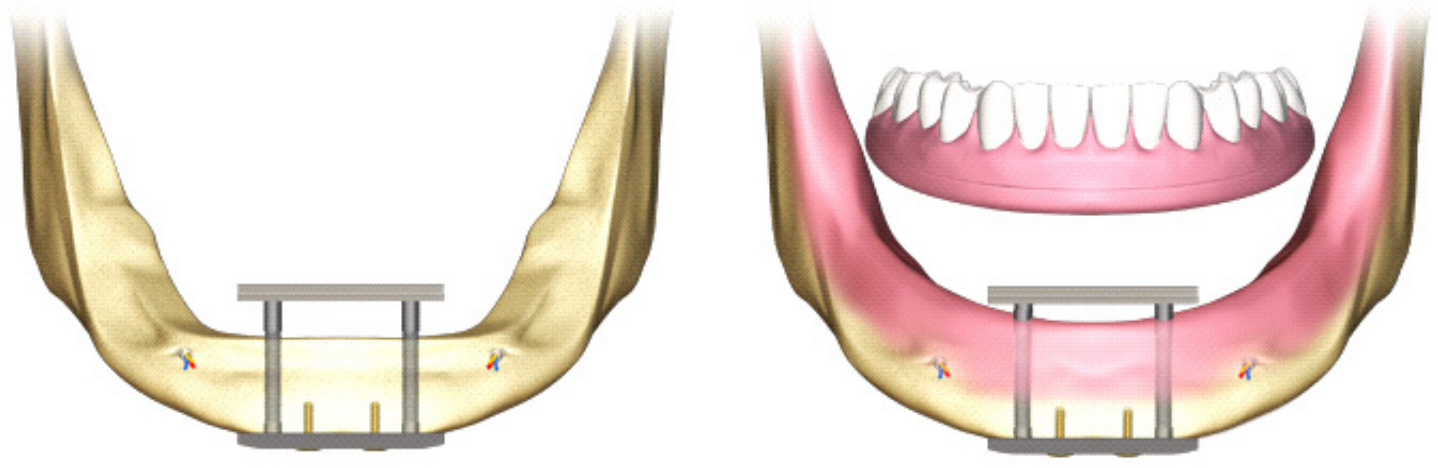

Fig. 2. Implante dental transóseo

(Fuente: http://www.1888implant.com/spanish/dental-implants.html\#) 


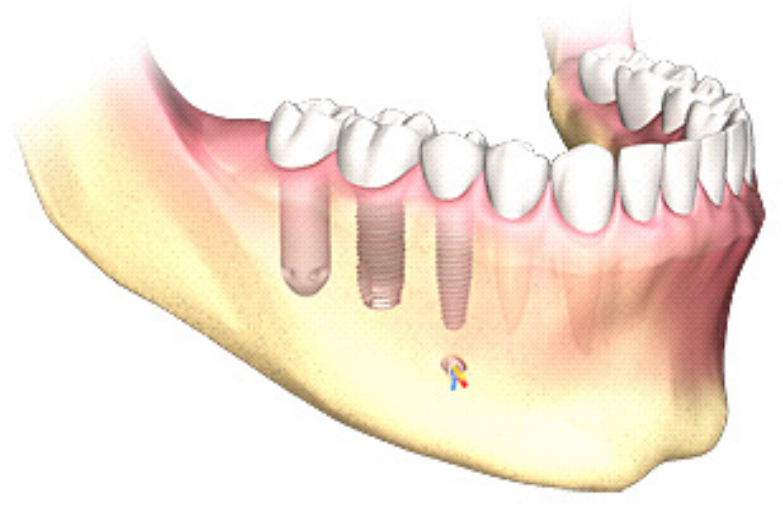

Fig. 3. Implantes dentales endoóseos.

(Fuente: http://www.1888implant.com/spanish/dental-implants.html\#)

Asimismo, cabe destacar que los implantes superiósticos y transóseo tampoco son empleados habitualmente por los odontólogos, ya que los porcentajes de éxito obtenidos por los mismos han resultado ser de carácter desigual. Por tanto, se analizará principalmente en este trabajo a los implantes de carácter endoóseo, ya que, debido a su efectividad, son los más empleados por los odontólogos y considerados como objeto de estudio por la mayor parte de los investigadores.

Respecto a estos últimos, es posible clasificarlos de acuerdo a su forma o diseño en [13]:

- Implantes de aguja

- Implantes de lámina (Fig. 4)

- Implantes de disco

- Implantes de raíz (Fig. 5) 


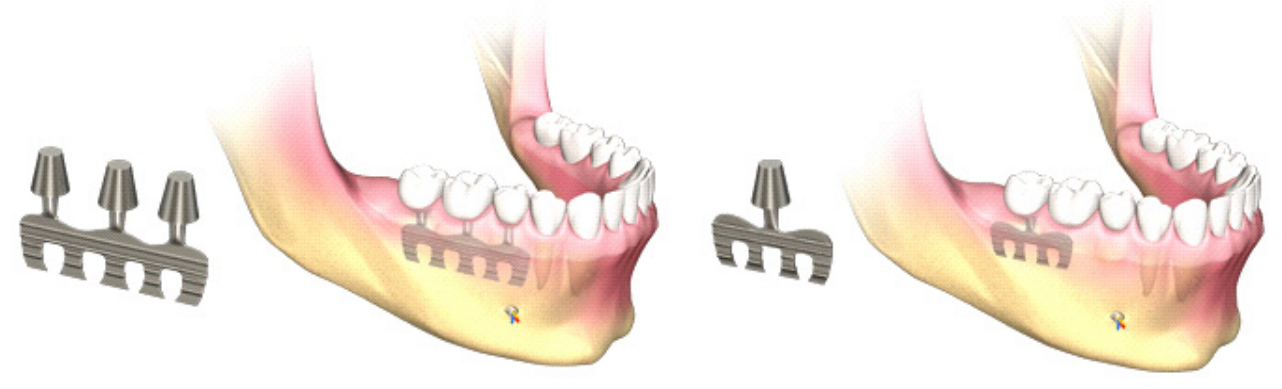

Fig. 4. Implantes de lámina

(Fuente: http://www.1888implant.com/spanish/dental-implants.html\#)

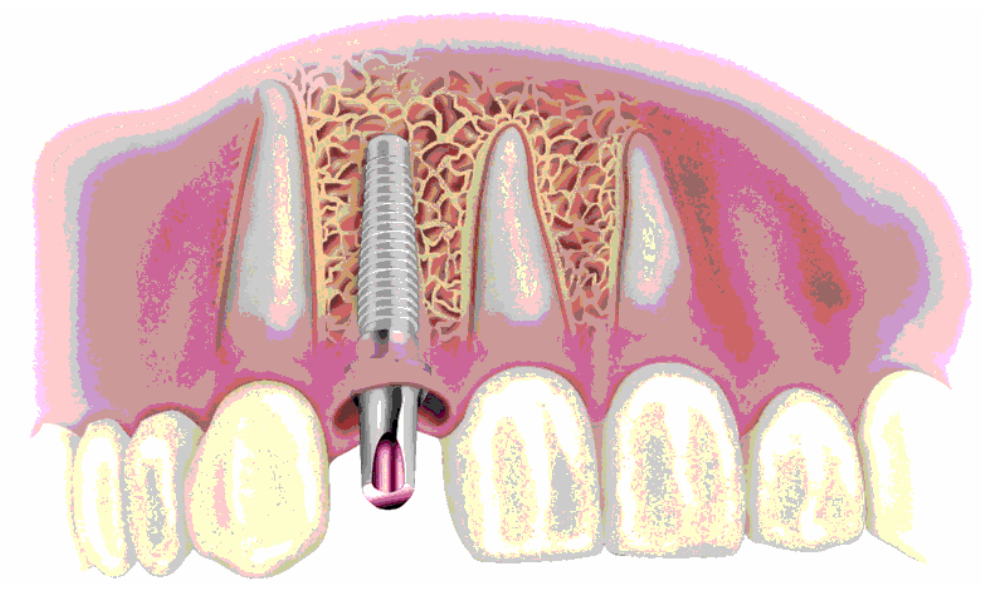

Fig. 5. Implante de raíz

(Fuente: http://medicoscr.net/implantes-dentales.php).

Los implantes de raíz son los más empleados en la actualidad. Una subclasificación de los mismos puede considerarse de la siguiente manera (Fig. 6): 
- Implantes de raíz cilíndricos

- Implantes de raíz roscados

- Implantes de raíz perforados

- Implantes de raíz troncocónicos
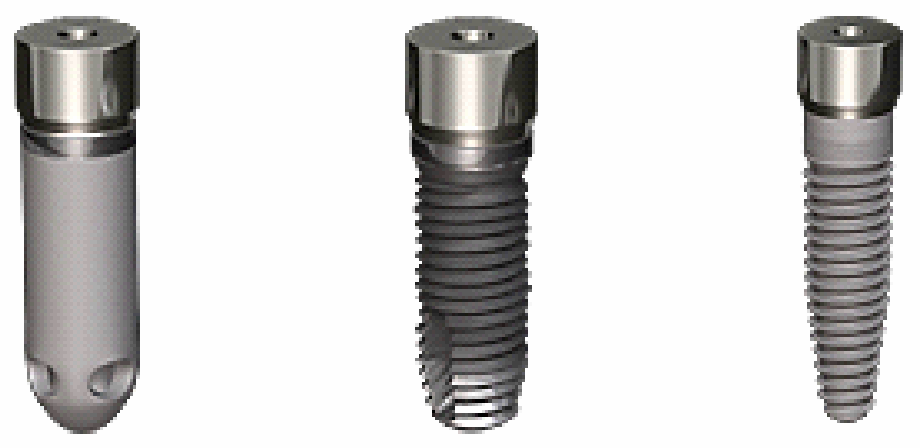

Fig. 6. Distintos tipos de implantes: a la izquierda, implante cilíndrico perforado; al centro, implante roscado; a la derecha, implante troncocónico roscado. (Fuente:

http://www.1888implant.com/spanish/dental-implants.html).

En ciertas ocasiones los odontólogos deciden utilizar algunas de estas formas combinadas (Fig. 6). Cabe destacar, de todos modos, que los implantes de raíz roscados y los implantes de raíz cilíndricos, sin perforaciones, son aquellos que han manifestado mayor éxito clínico y, por tanto, los más frecuentes entre los odontólogos [13]. Esto sucede porque los implantes perforados tienden a presentar una mayor tasa de infección, perimplantitis y fractura [14]. 
Los implantes de raíz roscados, por su parte, tienden a mostrar mejores resultados en lo respectivo a la osteointegración que los cilíndricos, tal como se verá más adelante [18].

Respecto al material de elaboración de los implantes, la tendencia actual reside en la utilización de titanio o de sus aleaciones. Se trata de un material altamente biocompatible, pues su resistencia a la corrosión en el medio fisiológico y su capacidad de osteointegración han resultado ser harto efectivas [13].

Cuando el implante está realizado, existen dos maneras de adherir el diente al éste. La primera se denomina cementado y consiste en atornillarla estructura intermedia al implante por medio de un tornillo. De este modo, la corona se cementa al diente [12] (Fig. 7).

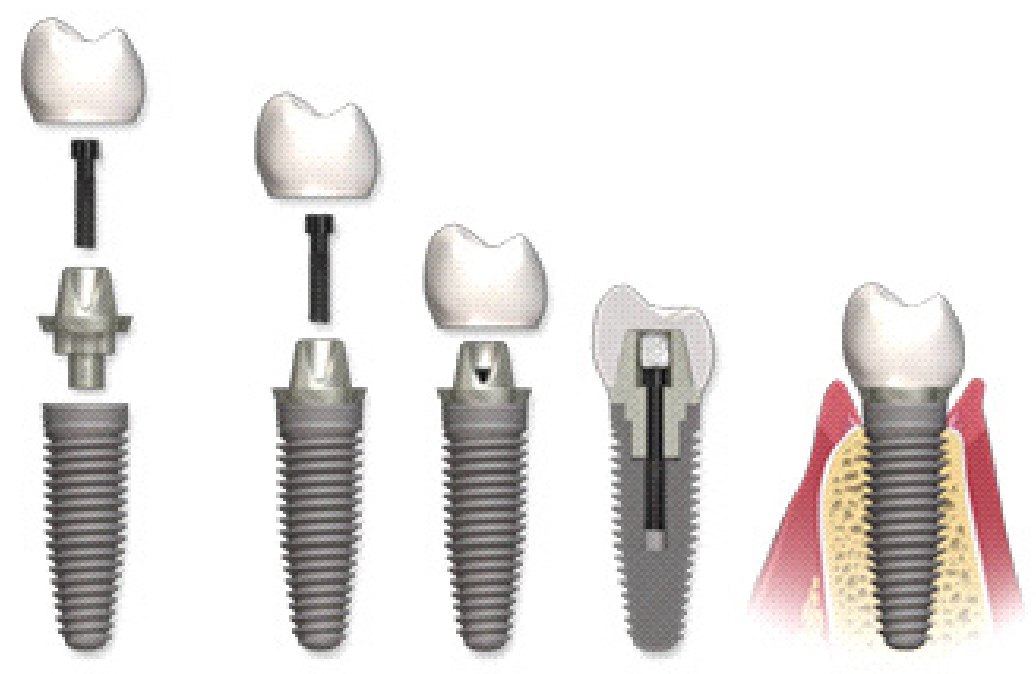

Fig. 7. Cementado

(Fuente: http://www.1888implant.com/spanish/dental-implants.html). 
La segunda forma, es el denominado método del tornillo retenido. Éste consiste en atornillar directamente el implante a través de la misma corona, cubriendo con relleno el orificio de acceso [12] (Fig. 8).

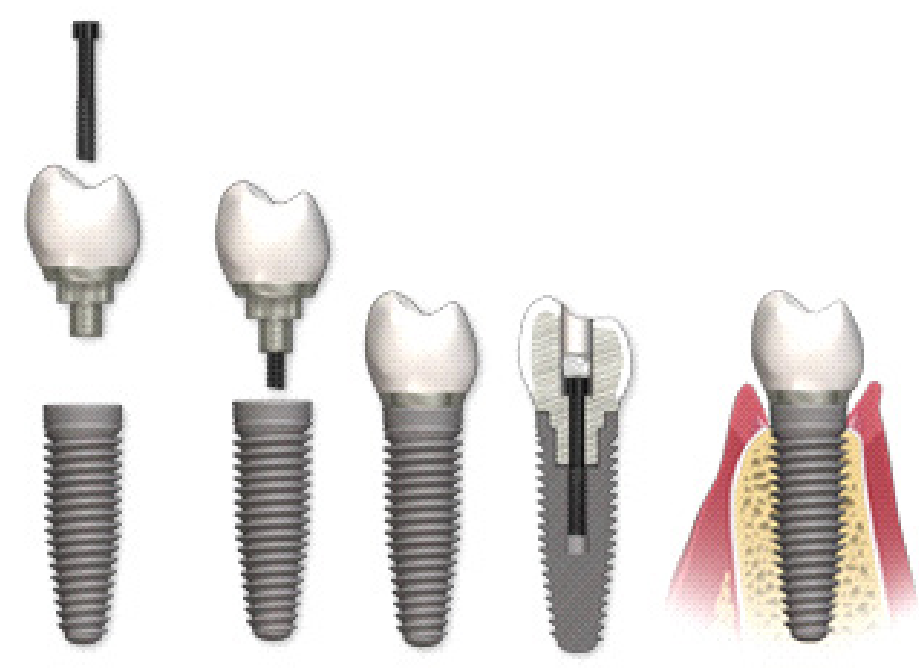

Fig. 8. Tornillo retenido

(Fuente: http://www.1888implant.com/spanish/dental-implants.html).

- Bases anatómicas de los implantes dentales

- $\quad$ El hueso

El hueso es un componente esencial para el éxito y la efectividad de los implantes. En efecto, el hueso opera como soporte en el que deben integrarse las implantaciones dentarias, tal como se vio en los apartados anteriores. En el tejido óseo los componentes extracelulares se encuentran mineralizados, por lo cual se constituye como un soporte rígido y resistente, aunque a su vez mantiene cierto grado de elasticidad [15]. 
Asimismo, los huesos operan como reservorios de calcio y otros iones inorgánicos útiles para el organismo. En efecto, son éstos los principales protagonistas de la homeostasis del calcio en todo el organismo. Además, mantienen los huesos un estado de constante dinamismo a lo largo de su vida en lo que respecta al crecimiento, la remodelación y la reabsorción, por lo cual los tejidos óseos son capaces de adaptarse a los diversos cambios que puedan sufrir ellos o su entorno [15].

Las células que componen el hueso están inmersas en una matriz extracelular que contiene diferentes sustancias básicas de proteoglicanos y proteínas varias, entre las que se destaca el colágeno de tipo I en forma de fibras. Entre los componentes minerales, es posible destacar los cristales de hidroxipatita, los cuales se depositan sobre el colágeno de tipo I. De este modo, se forma un tejido duro y rígido [15].

Existen diferentes células que componen el tejido celular óseo. Por un lado, están los osteoblastos, responsables de la síntesis y secreción de compuestos orgánicos e inorgánicos de la matriz extracelular del nuevo hueso, los osteocitos, que son osteoblastos atrapados por una matriz mineralizada, y los osteoclastos, involucrados en la reabsorción y la remodelación ósea. Estos tres tipos de células conforman el grupo de las Ilamadas células osteoprogenitoras [15]. 


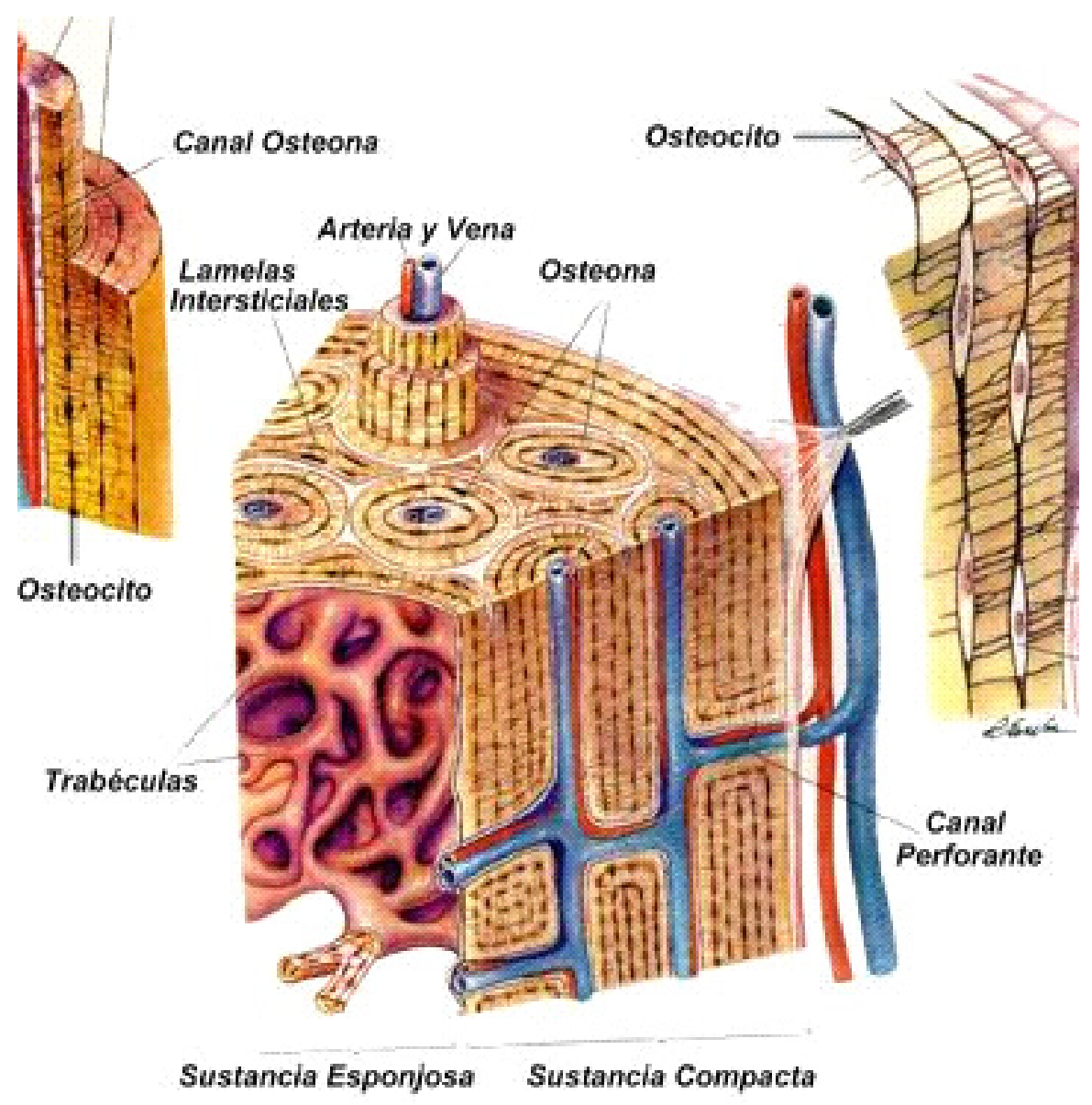

Fig. 9. Interior del hueso

(fuente:http://www.anatomiahumana.ucv.cl/morfo1/osteomorfo.html)

Cabe destacar que existen dos formas de hueso [15]:

- El hueso inmaduro: Es esa forma de hueso que origina el esqueleto embrional. A medida que el esqueleto embrional se va desarrollando, el hueso inmaduro se va reabsorbiendo y reemplazando por hueso maduro. Su constitución consta de una serie de fibrillas colágenas distribuidas irregularmente, así como de una mineralización escasa e irregular de la matriz extracelular. 
- El hueso maduro o laminar: Es mucho menos flexible y más duro que el hueso maduro, deformándose con mayor facilidad. Tiene, asimismo, una distribución mineral dentro de la matriz extracelular casi completamente uniforme.

El hueso laminar está compuesto por una serie de capas sucesivas dotadas de una alta organización estructural. Muchas veces está compuesto por una masa de carácter sólido, denominada hueso compacto o cortical. Se trata de una capa exterior protectora, que rodea a la mayor parte de los huesos. Su constitución está conformada por osteonsas, una serie de formaciones cilíndricas que se disponen de manera adyacente. La irrigación y la inervación del hueso compacto o cortical se realizan a través del llamado túnel haversiano, el cual está rodeado de una lamela. Los osteocitos se ubican en la lamela y se comunican entre sí mediante pequeños canales denominados canalículos [15].

El hueso trabecular o esponjoso se encuentra ubicado por debajo de la capa del hueso cortical. Se trata de una malla compleja, la cual sirve como una suerte de andamio que opera de modo tal que el hueso pueda mantener su forma cuando se encuentra expuesto a esfuerzos mecánicos. Al no estar formado estructuralmente por osteonas, como es el caso del hueso cortical, cuando se lo observa por el microscopio parece tener una estructura esponjosa, lo que le da su nombre [15].

El periostio está compuesto por dos capas. La primera, de carácter externo es densa y fibrosa. La segunda, interna, es blanda y rica de vasos sanguíneos y células. Durante los procesos de curación de fracturas, dichas células suelen ayudar a la creación de una cantidad extra de callo óseo. El grosor del periostio disminuye con los años, haciéndose ésta cada vez más fino. La capa osteogénica tiende a desaparecer por 
completo cuando el esqueleto alcanza una madurez considerable. Sin embargo, las células del periostio no dejan de producir hueso nuevo a lo largo de toda la vida [15].

La regulación de la nucleación y el crecimiento de los cristales de hidroxiapatita parecen estar determinadas por las fibras de colágeno de tipo I presentes en el hueso. En efecto, dichas fibras colaginosas están controladas por una serie de proteínas, las cuales incluyen proteoglicanos pequeños, dotados de una cadena con densidades altas de cargas negativas. Se estima que una de las funciones principales de esas moléculas con carga eléctrica sea aquella de regular e influenciar la deposición y el crecimiento mineral $[12,15]$.

El endostio es similar al periostio, pero se diferencia de éste ya que sólo contiene una capa de células, compuesta por células progenitoras óseas, osteoblastos y osteoclastos. El periostio y el endostio son aquellas dos fuentes encargadas de reparar los daños producidos en el tejido óseo $[12,15]$.

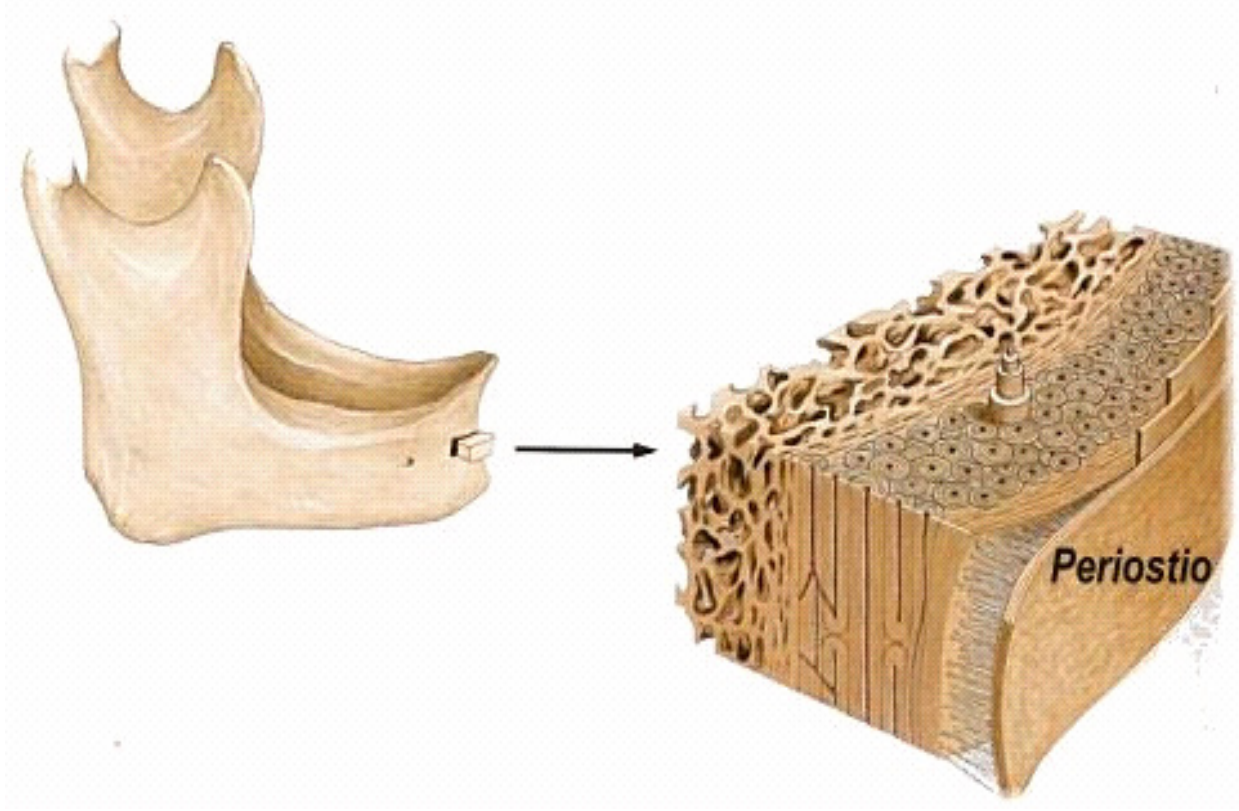

Fig. 10. Periostio mandibular

(fuente:http://www.anatomiahumana.ucv.cl/morfo1/osteomorfo.html) 
- La mandíbula y el maxilar

La mandíbula o maxilar inferior es un hueso plano, simétrico, de carácter impar y central. Se sitúa en la parte inferior y anterior de la cara. Su forma es análoga a la de una herradura, presentando un plano horizontal y dos verticales, que se sitúan uno de cada lado. Su borde superior o reborde alveolar está dotado de una serie de orificios, de los cuales nacen las raíces de los dientes inferiores [12, 15].

La parte media de la mandíbula presenta la llamada sínfisis mentoniana. Se trata de una línea de unión entre las dos hemimandíbulas, a lo largo de la cual hay una serie de crestas de osificación. Dichas crestas constituyen la llamada protuberancia mentoniana [12].

A la altura del segundo molar, se encuentran, de cada lado, los orificios mentonianos. Por dichos orificios entran y salen los nervios y los vasos que irrigan el hueso. En la cara externa está el surco denominado línea oblicua externa y en la cara interna o lingual, una serie de rugosidades llamadas apófisis genianas, que operan como punto de inserción del grupo de músculos de la orofaringe. Además, también en la cara interna de la mandíbula, se encuentra la línea oblicua interna, que es un surco que sirve de punto de inserción para el músculo milohioideo, que mueve la boca [12]. 


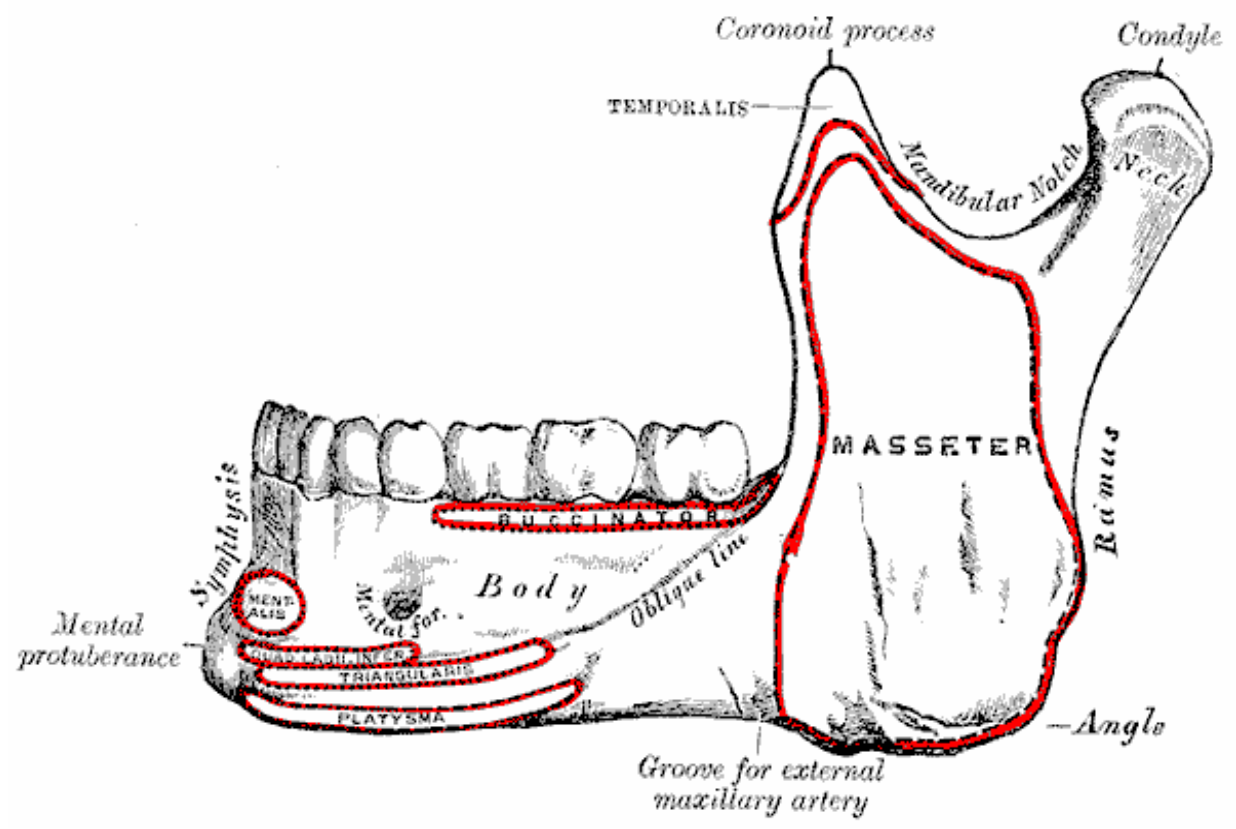

Fig. 11. Vista de la cara exterior de la mandíbula.

(Fuente: http://www.bartleby.com/107/)

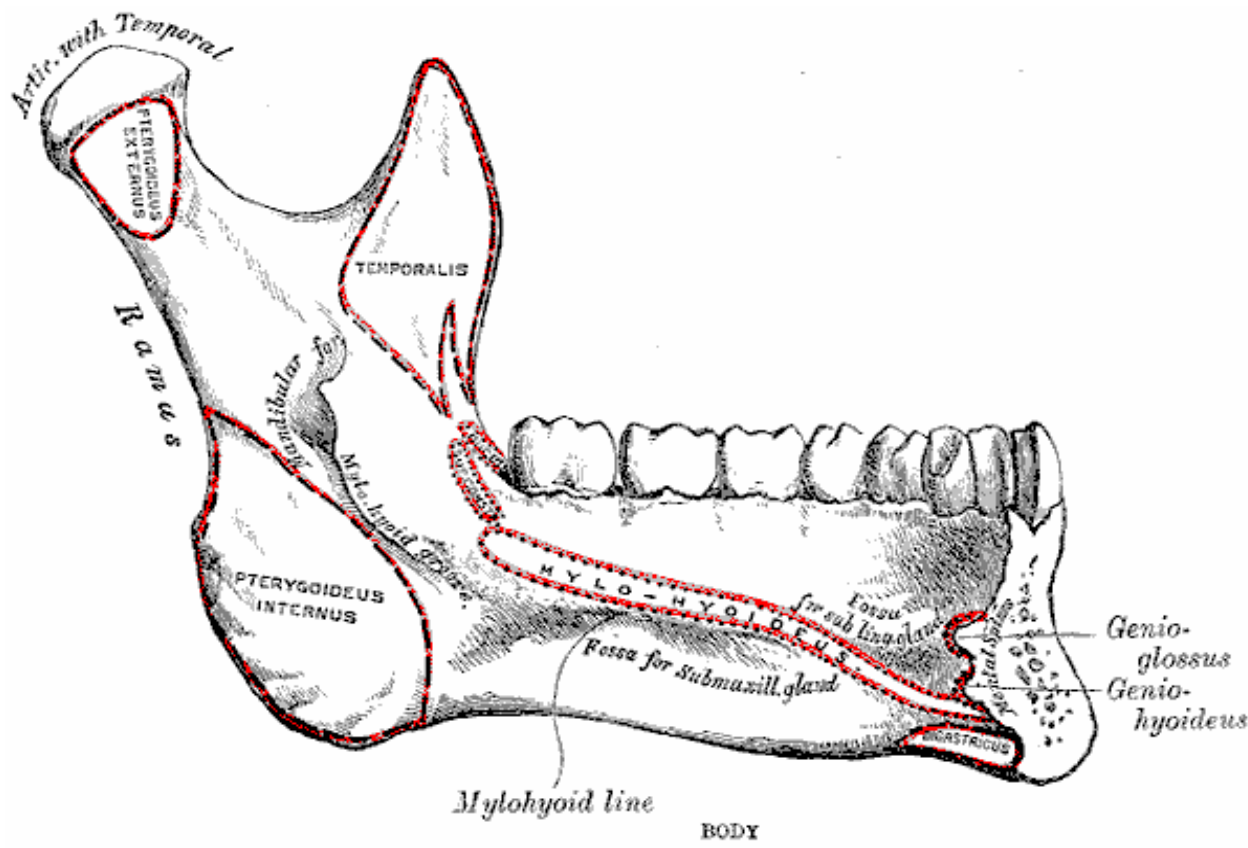

Fig. 12. Vista de la cara interior de la mandíbula.

(Fuente:http://www.bartleby.com/107/) 
El maxilar superior o, simplemente, maxilar es una hueso par, corto, de forma irregular, dotado de dos caras (una interna y otra externa), cuatro bordes y cuatro ángulos. Dentro del maxilar superior de encuentra el seno maxilar, es decir una cavidad recubierta de mucosa y rellana de aire [12].

El maxilar presenta un cuerpo, una base mayor (interna) y una base menor (externa), así como una serie de prolongaciones: el proceso frontal, el cual articula con el hueso frontal, el proceso cigomático, el cual articula con el hueso cigomático, el proceso palatino, que constituye la mayor parte (aproximadamente dos tercios) del paladar duro, y el proceso alveolar. Es en este último donde se implantan los dientes [12].

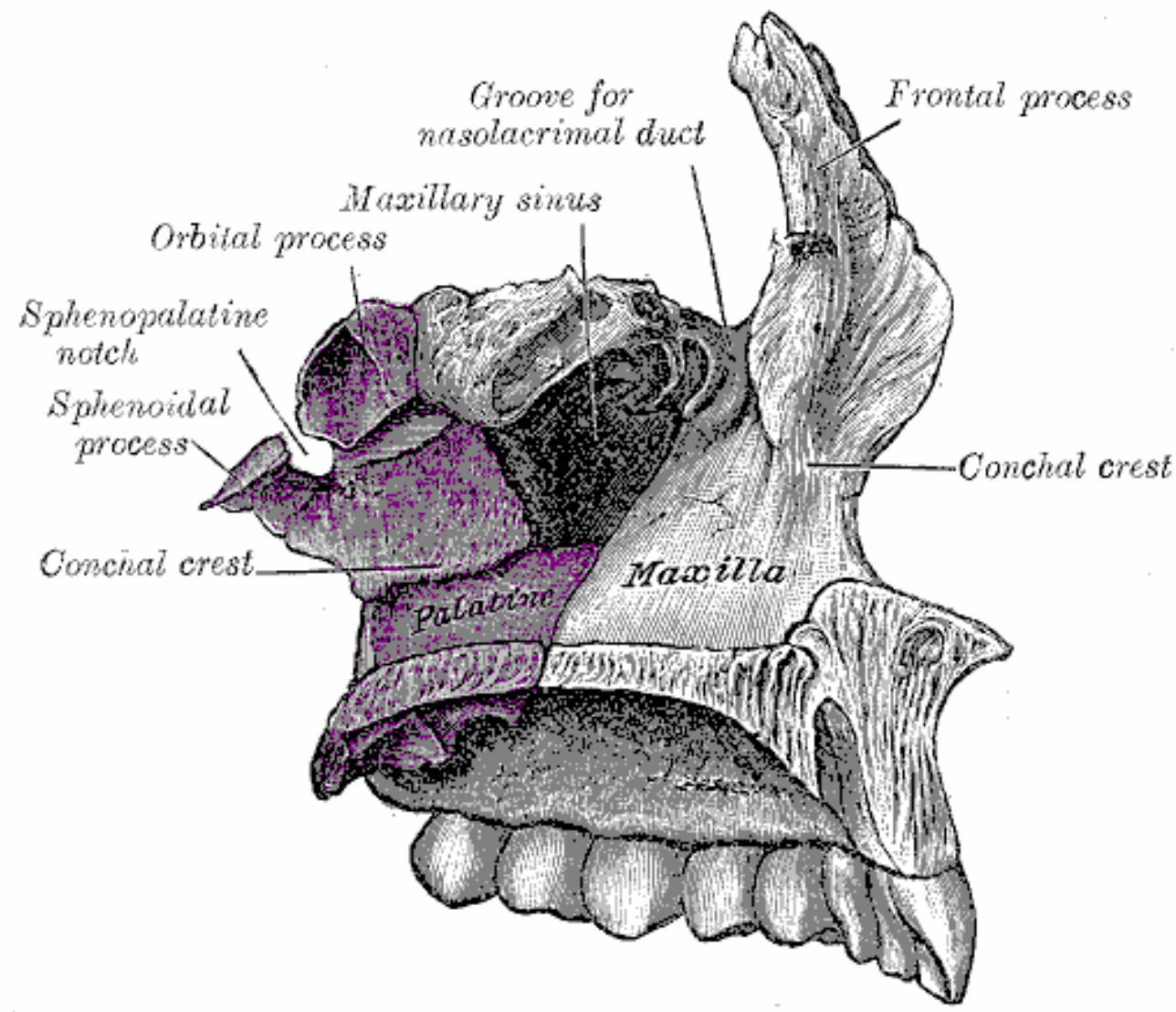

Fig. 13. Vista interna del maxilar superior.

(Fuente:http://www.bartleby.com/107/) 


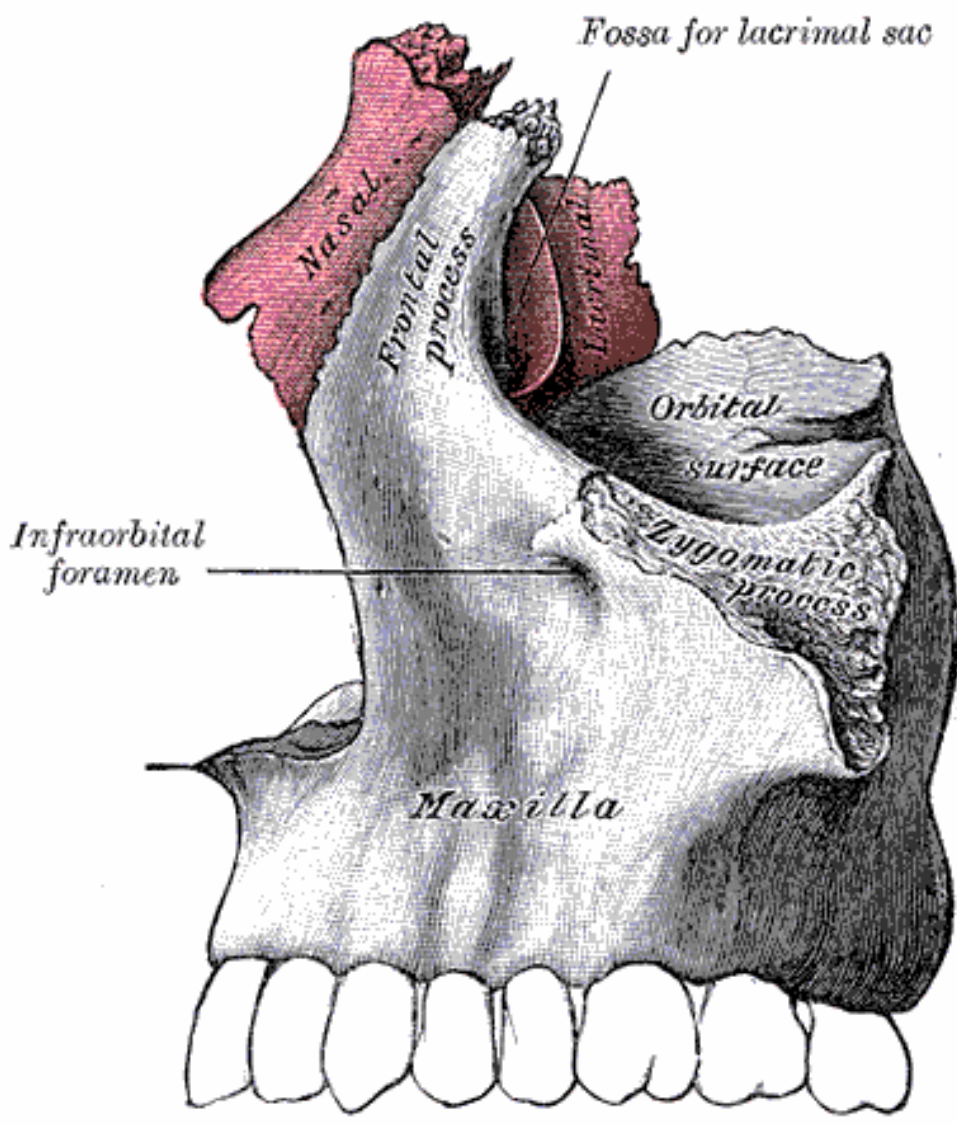

Fig. 14. Vista externa lateral del maxilar superior .

(Fuente: http://www.bartleby.com/107/) 


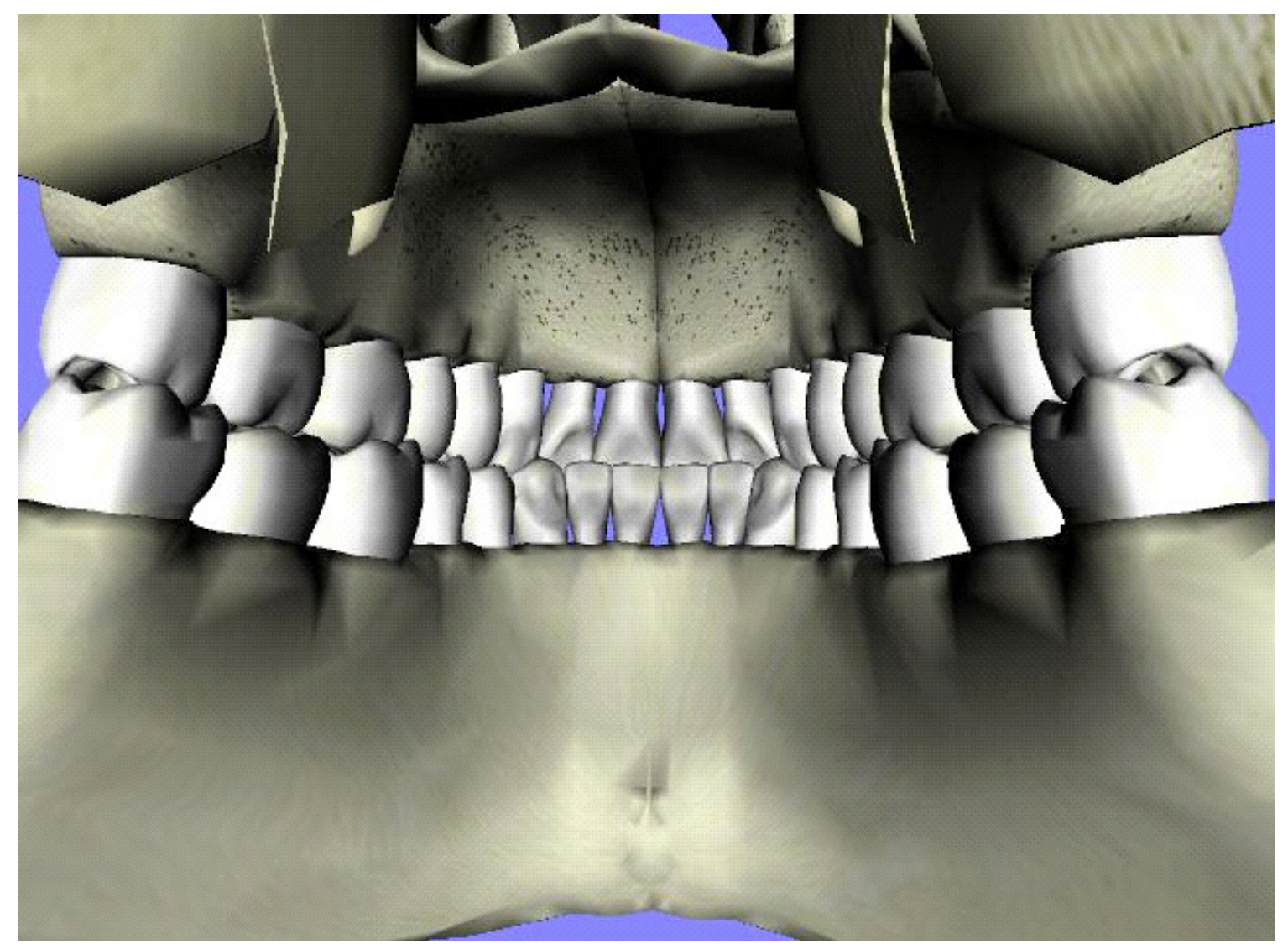

Fig. 15. Vista interna de ambos maxilares y los dientes. (Fuente: http://es.wikipedia.org/wiki/Diente\#mediaviewer/File:Denticao.jpg)

- Configuración del proceso alveolar maxilar

Al proporcionar el proceso alveolar maxilar un espacio mínimo para las raíces de los dientes, aquellas de los incisivos y las de los caninos protruyen en la cara maxilar anterior de la cresta alveolar. Dicha protrución desaparece en dirección occipital. Es por este motivo que a partir de la cresta infracigomática, que separa la porción anterior del cuerpo maxilar de la fosa infratemporal, apenas pueden notarse. Dicha cresta tiene su origen en el proceso cigomático del maxilar superior, aproximándose a la región de los primeros molares en la pared alveolar vestibular. Asimismo, cabe destacar, que la cresta en cuestión opera 
como el pilar de soporte más importante en la desviación de las fuerzas masticatorias de los dientes maxilares [16].

El proceso alveolar maxilar finaliza detrás del último molar en el tubérculo retromolar, cuyo límite está por delante de la fisura pterigomaxilar. A lo largo de la vida, puede variar considerablemente [12, $16]$.

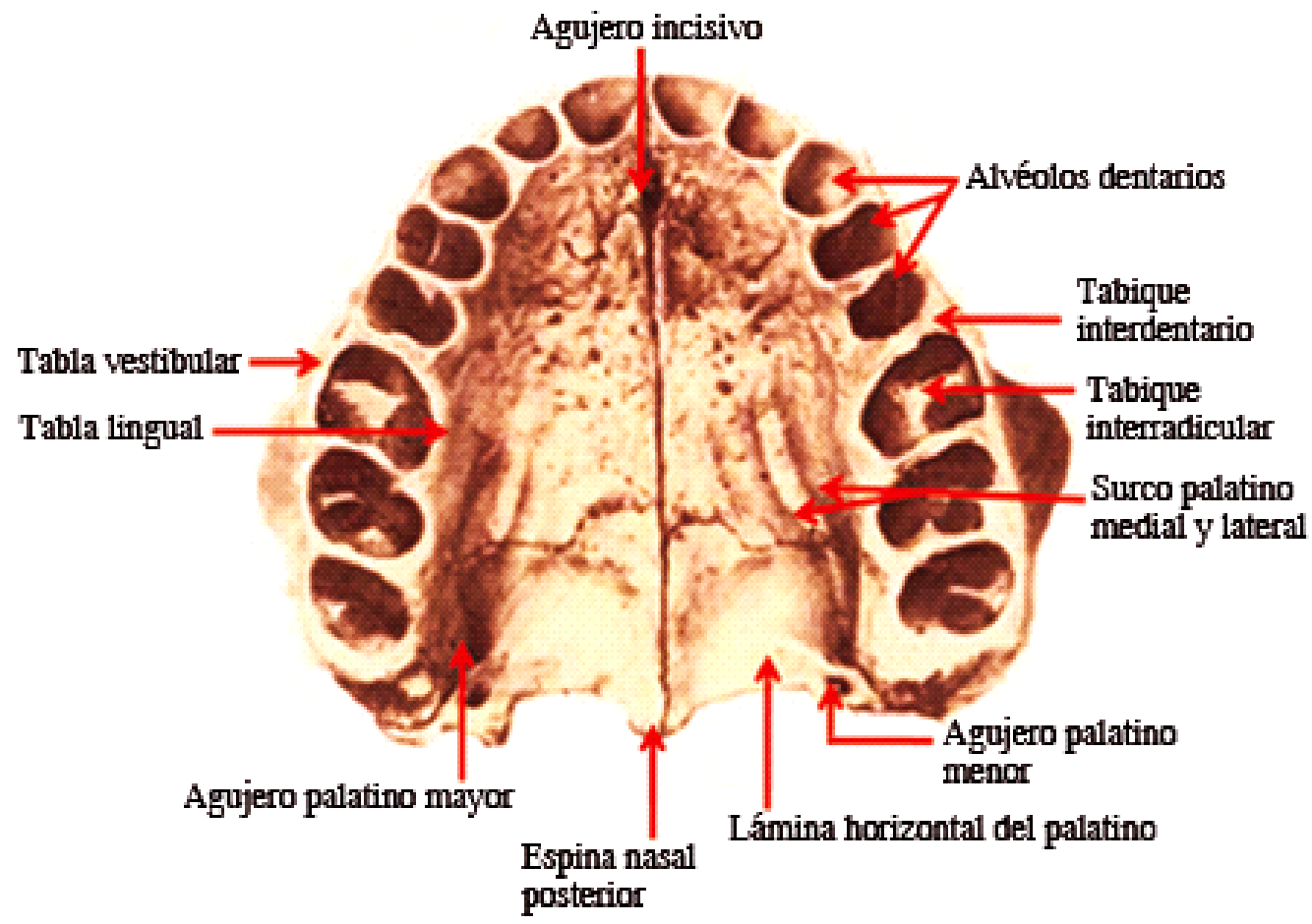

Fig. 16. Arcada alveolar maxilar (Fuente: http://gsdl.bvs.sld.cu)

- Los ejes dentarios del maxilar

En lo que respecta a los ejes dentarios del maxilar, cabe destacar que éstos son oblicuos al eje vertical del cráneo, no estando alineados con él. Por tanto, las raíces del arco dental del maxilar están más próximas. Las raíces del arco dental del maxilar yacen más cercanas 
entre sí que las coronas de los dientes. Estas últimas, parecerían muchas veces ladearse hacia afuera ligeramente. Los ejes de los incisivos tienden a desviarse unos $3^{\circ}$ y los de los molares aproximadamente $2^{\circ}$ [12].

- Estructura de la pared alveolar maxilar

La pared alveolar vestibular es prácticamente el doble de gruesa que la pared palatina. Los septums interdentales tienen un grosor que puede ir desde los $0,7 \mathrm{~mm}$ a las $1,4 \mathrm{~mm}$. Su constitución es de hueso compacto y esponjoso, tal como sucede en otras partes de la pared alveolar. Cabe destacar que el hueso compacto en cuestión posee, a diferencia del presente en otras partes del cuerpo, haces de fibras cemento alveolares que se irradian hacia el interior [12].

El ligamento peridontal de los dientes sirve para proporcionar suspensión resiliente. Asimismo, transmite las cargas al hueso esponjoso adyacente hacia las raíces, adquiriendo las trabéculas óseas una determinada orientación en trayectoria. Ésta, gracias al papel de la cresta infratemporal en la desviación de la presión masticatoria de los dientes maxilares, adquiere una mayor pronunciación en la región del primer molar $[12,16]$.

Las trabéculas verticoradiales tienen su origen en el hueso compacto. Tras divergir en forma de abanico, se insertan en el hueso compacto de la pared del seno maxilar o del suelo nasal [12].

Los dientes maxilares están en estrecha relación con el seno maxilar y la cavidad nasal. El hueso esponjoso de la pared alveolar se continúa, en la zona de los incisivos, con el hueso compacto fino presente en el suelo nasal. Habitualmente, las raíces de los caninos, gracias a su longitud, alcanzan el foramen infraorbitario de la pared nasal lateral. Asimismo, el hueso esponjoso de los procesos alveolares de los 
premolares y molares comparte su límite con el hueso compacto del seno maxilar $[12,16]$.

La pérdida dentaria puede causar la atrofia de la pared alveolar e, incluso, hundir el suelo del seno maxilar hacia abajo, quedando así tan solo, después de unos cuantos años de haber perdido las piezas dentales, una fina lámina ósea como separador entre la pared del alveolo vacío y el seno maxilar [16].

- Ejes dentarios de la mandíbula

Los ejes de los dientes verticales mandibulares están inclinados hacia adentro, respecto al eje vertical del cráneo. De este modo, las coronas de lados opuestos a la mandíbula yacen más próximas entre sí que las raíces [12].

- Estructura de la pared alveolar mandibular

Las trabéculas de hueso medular de la pared alveolar mandibular poseen prácticamente las mismas características que presenta el maxilar. Sin embargo, el modelo verticoradial peridentario es más constante en la zona de la mandíbula que en el maxilar. Esto se explica gracias a la ausencia del contrafrente que se desarrolla en la cresta infratemporal del maxilar y que dispersa las fuerzas de la masticación $[12,16]$. 


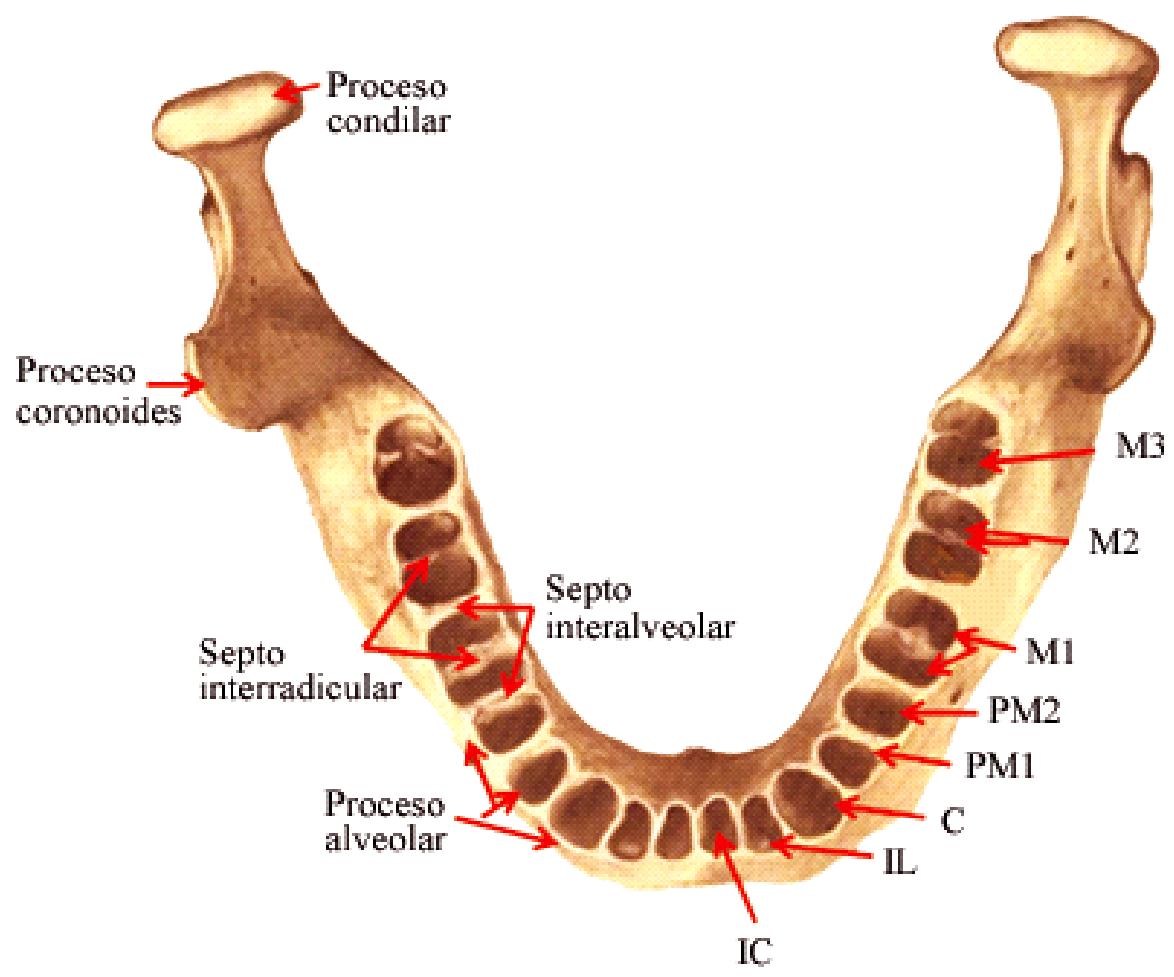

Fig. 17. Arcada alveolar mandibular (Fuente: http://gsdl.bvs.sld.cu)

- Inervación de los dientes y la encía

Los dientes maxilares están dotados de una serie de fibras que pasan, en su mayoría, desde los dientes maxilares a través de las ramas del nervio maxilar. Existen, asimismo, nervios aferentes desde los caninos incisivos conducidos desde el nervio oftálmico. Cabe destacar que el ganglio trigémino opera como el centro periférico de todos los nervios sensitivos.

Los nervios alveolares superoposteriores se separan del nervio infraorbitario justo antes de que éste se introduzca en la órbita a través de la fisura orbitaria inferior. Los nervios pasan por la fisura pterigomaxilar desde la fosa pterigopalatina, discurriendo de forma oblicua hacia abajo 
del tubérculo maxilar, para pasar luego a través de los forámenes de los canales alveolares, a partir de los cuales las ramas dentales interalveolares descienden hasta las raíces de los molares y los septums interdentales interradiculares. La rama craneal de los nervios alveolares posterosuperiores discurre, tras dejar ramas menores en la mucosa del seno maxilar, más allá, dispersándose del hueso medular del maxilar anterior. En dicho plexo se introducen también los nervios alveolares superiores anterior y medio, ramificándose del nervio infraorbitario e introduciéndose en el hueso compacto del cuerpo maxilar [12].

En la región de la fosa canina está ubicad en el cuerpo maxilar, debajo del foramen infraorbitario. Allí, el plexo dental es particularmente denso. La zona anterior al plexo es denominada plexo canino, conectado con el nervio oftálmico, lo que explica la extensión del dolor de dientes a la parte frontal superior de la cara. Asimismo, a partir del nervio nasal lateral, que desciende por la mucosa nasal lateral, se abre una gruesa rama que penetra por dicha pared, introduciéndose en el plexo canino [12].

En lo respectivo a la inervación de los dientes mandibulares, las fibras sensitivas de éstos se introducen en la tercera rama del trigémino, mediante el nervio alveolar inferior. El nervio alveolar inferior transcurre, dentro del canal mandibular, por una vaina de periostio rígida, la cual va desde el foramen mandibular hasta el mentoniano, envolviendo también la vena y la arteria alveolar inferior y los vasos linfáticos centrales de los dientes mandibulares [12].

En lo que respecta a la inervación de las encías, la encía palatina es inervada por dos nervios: el palatino y el nasopalatino. El plexo dental inerva la encía vestibular. La encía labial es inervada por el plexo canino [12]. 
- Irrigación de los dientes y la encía

El aporte sanguíneo que reciben los dientes maxilares se da a través de un circuito vascular interior y exterior. Las arterias alveolares pósterosuperiores, que surgen directamente de la arteria maxilar antes de que entre en la fosa pterigolopalatina a partir de la fisura pterigomaxilar, contribuyen, desde el lado dorsal, al desarrollo del circuito vascular exterior. La arteria nasal lateral, que surge de la arteria oftálmica, a través de la arteria nasociliar, y las ramificaciones de arteria infraorbitaria, contribuyen también a la formación del circuito vascular exterior [12].

Dicho circuito abastece de flujo sanguíneo a los dientes maxilares, así como a la encía adyacente. Está formado exclusivamente a partir de las ramificaciones de las ramas terminales de la arteria maxilar y de una mínima contribución de la arteria palatina descendente [12].

Los dientes mandibulares son abastecidos ellos también por un circuito vascular, cuyo vaso principal es la arteria alveolar inferior. Ésta transcurre por el llamado canal alveolar, llegando a los dientes mandibulares mediante ramos dentales. Asimismo, forma un arco exterior que llega a la arteria facial a través de dos arterias: la mentoniana y la submentoniana, y se conecta con la arteria lingual profunda a través de un arco interior y con la arteria sublingual mediante los ramos interincisivos [12].

El drenaje sanguíneo de los dientes maxilares y mandibulares, así como de las encías adyacentes, se realiza a través de la vena alveolar superior y la vena alveolar inferior hasta el plexo pterigoideo. Éste se extiende sobre la cara lateral del músculo pterigoideo medio y conduce la sangre de la vena retromandibular a través de las venas maxilares [12]. 
- Restricciones fisiológicas de la implantología en el hueso

La descripción en cuestión de las estructuras anatómicas y de las relaciones topográficas de la boca, es útil para dar cuenta de las restricciones fisiológicas presentes en la implantología en el hueso. Para realizar un implante de manera exitosa es necesario considerar, en efecto, la disposición ósea, las estructuras óseas, el aporte nervioso y vascular de las diversas regiones implicadas en la intervención y la relación topográfica existente entre los dientes maxilares y la cavidad nasal y el seno maxilar.

Es de acuerdo a estos factores que se pueden clasificar las diversas localizaciones en virtud de la realización del implante del siguiente modo [12]:

Localizaciones favorables: Las localizaciones favorables para la realización del implante son las que se en la mandíbula inferior, entre los dos forámenes mentonianos, y en la región mandibular cercana a los dientes posteriores. Es preferible realizar las intervenciones en cuestión en las zonas de membrana mucosa queratinizada insertada y firme.

Localizaciones condicionalmente favorables: Es condicionalmente favorable la región maxilar hasta los segundos premolares. No así en el sector posterior por la ubicación del nervio dentario inferior lo cual dificulta su colocación. 
- La osteointegración y la implantología dentaria

- La osteointegración

Se puede definir la osteointegración o anquilosis como una conexión directa, de carácter estructural y funcional, que se establece, tras la realización de una implantación, entre los dos componentes principales de la misma: la superficie del implante sometido a carga funcional y el hueso vivo. Es necesario, por tanto, que exista una determinada conexión o contacto directo, al menos bajo una mirada mediada por el microscopio óptico, entre el titanio y la superficie ósea, en pos de que el implante sea exitoso, es decir que se integre y perdure. Para poder generar y mantener dicha integración, a decir la osteointegración, resulta fundamental, entonces, conocer las capacidades de cicatrización y reparación propias del tejido óseo circundante [19].

La osteointegración opera así como una estrategia, necesaria, cabe destacar, para el éxito y la perdurabilidad de la implantación dentaria. Cabe destacar la importancia de dicha estrategia en la historia de la práctica terapéutica odontológica [2]. En efecto, a partir de los años ochenta del pasado siglo, la investigación a este respecto ha aumentado su producción de páginas progresiva y considerablemente, siendo ésta la estrategia considerada como más efectiva en lo referente a la implantación dentaria, preferida por sobre otras estrategias como ser la fibrointegración [21].

Esta última, que pretendió en algún momento desarrollarse como estrategia alternativa a la osteointegración, está orientada al aprovechamiento de la encapsulación del implante con los tejidos conectivos estratificados y blandos que conforman el entorno del mismo. Sin embargo, es preciso destacar que, si bien en algún momento muchos investigadores se volcaron al desarrollo de dicha estrategia, ésta, que pretendía lograrse mediante la imitación del ligamento periodontal, 
alcanzando su amortiguación de tensiones y funciones sensoriales, ha devenido en un fracaso [21].

La sustitución de piezas dentales por prótesis osteointegradas ha resultado ser de enorme significación en la historia de la odontología. En efecto, las ventajas de las mismas son claras, ya sea desde el punto de vista estético, como funcional. De acuerdo con Misch [20], las mejoras efectuadas por las implantaciones osteointegradas pueden resumirse en los siguientes puntos:

- Mantenimiento del hueso

- Mantenimiento de la buena posición de las piezas dentarias

- Mantenimiento de las dimensiones verticales

- Buena oclusión

- Cargas oclusales directas

- Aumento en la fuerza oclusal

- Mejor masticación

- Mayor retención y estabilidad

- Mejor fonética

- Mejor percepción de la posición de los dientes y de las fuerzas que éstos ejercen

- Mayor satisfacción por parte del paciente, lo que genera una mejora en la satisfacción psicológica 
Tradicionalmente, la mayor parte de la aplicación de los implantes de titanio osteointegrados son aplicados, en la actualidad, a pacientes totalmente edéntulos. Cabe destacar que la gran reabsorción ósea presente, por lo general, en la mandíbula edéntula. Es por ello que la retención de prótesis removibles, que se basa en la interacción mecánica entre la prótesis y el tejido blando circundante, se torna con el tiempo, en dichos pacientes, dificultosa. Esto sucede porque la reabsorción ósea provoca una reducción considerable del volumen de tejido [20].

Es por ese motivo que se han empleado, de manera alternativa, las prótesis implantosoportadas, las cuales suelen fijarse a los implantes 0 bien por cementación o bien mediante la utilización de tornillos [20].

Los implantes dentales para la restauración de pacientes edéntulos parciales es una práctica que comenzó a utilizarse posteriormente. Los pacientes carentes de una pieza dental individual o de varias piezas dentales tratados mediante implantes osteointegrados suelen mostrar resultados harto positivos [12].

Cabe destacar, sin embargo, que a pesar del significativo éxito de este tipo de tratamientos, la reciente historia de la implantología dentaria de titanio basada en la osteointegración, que tiene poco más de una veintena de años, continúa siendo desarrollada por los investigadores, en pos de obtener cada vez mejores resultados. Respecto a esto último, los investigadores tienden a orientarse en la determinación de los factores que se ven involucrados en la osteointegración, en pos de mejorar las prácticas terapéuticas odontológicas mediante implantaciones dentarias.

- Factores influyentes en la osteointegración

De acuerdo con Albrektsson et al. (1981) [22], es posible identificar seis factores que inciden sobre el éxito del implante: 


\section{- 1. El material del implante}

Como se ha indicado más arriba, el material más frecuentemente utilizado para la realización de implantes dentales es el titanio. Cabe, sin embargo, dar cuenta de las propiedades necesarias para que un material sea apropiado para llevar a cabo dicha práctica odontológica.

Los materiales no vivos a ser empleados en una intervención clínica de este tipo deben ser capaces de interactuar de firma adecuada con los sistemas biológicos. Por tanto, el material de fabricación de los implantes dentales debe ser un biomaterial. El buen comportamiento de este material en el medio biológico consistirá en la posesión de determinadas propiedades que lo hacen apto para cumplir la función terapéutica a la que está destinado. En otras palabras, es necesario que dicho material sea biocompatible, mecánicamente resistente, resistente a la degradación, conformable y disponible [23].

Que el material en cuestión sea biocompatible es la premisa principal para su utilización o no. En efecto, lo que esto significa es que del biomaterial dentro de los tejidos biológicos no provocará respuestas bioquímicas que puedan llegar a ser perjudiciales para el correcto funcionamiento de dichos tejidos o del organismo en general [24].

Cabe, sin embargo, destacar que ningún material es en sí biocompatible. La biocompatibilidad es, de hecho, una propiedad relacional, la cual varía de acuerdo al organismo en el que es aplicado el biomaterial. Se puede, siguiendo estudios estadísticos, suponer que ciertos materiales son más biocompatibles que otros, pero de ninguna manera se puede asegurar la biocompatibilidad de un material a priori, es decir antes de realizar la intervención clínica [23, 24]. 
Asimismo, suponiendo su biocompatibilidad, es posible clasificar los materiales en dos tipos: los materiales bioinertes y los materiales bioactivos. Los primeros son aquellos materiales que no son tóxicos y no tienden a generar respuestas químicas y biológicas en el organismo. Los segundos, en cambio, son materiales que, no siendo tóxicos, actúan sobre el organismo [22].

Se considera al titanio como un material bioinerte, mientras que la hidroxiapatita es tenido como material bioactivo. El titanio es empleado, entonces, gracias a sus cualidades mecánicas. La hidroxipatita, en cambio, se utiliza en implantología dental para recubrir el implante de titanio, ya que es bioactiva respecto a la superficie ósea. Esto implica, por tanto, que este último material genere una reacción química in vivo con el hueso, siendo capaz de enlazarlo con el implante, permitiendo así la osteointegración [24].

En lo respectivo a las cualidades mecánicas del titanio, este posee un módulo de elasticidad de 100/110 GPa, un límite elástico de 170/483 MPa y una resistencia de tracción de 240/550 MPa. Dichos valores resultan suficientes para soportar las diferentes cargas mecánicas que el implante puede llegar a recibir en la boca y, a su vez, no perjudica, por poseer un módulo de elasticidad menor al de otros metales, al hueso [25].

Además, el titanio es un material altamente reactivo. Esto induce a su rápida oxidación $\mathrm{y}$, por tanto, al hecho de que esté siempre recubierto por una capa de óxido, que protege el material y evita su ionización. Por tanto, el titanio se constituye en un material apto para los implantes dentales, pues posee una alta resistencia a la corrosión [26].

De acuerdo a las normas internacionales, existen cuatro grados diferentes de titanio que pueden ser usados para su aplicación médica. Los grados en cuestión son clasificados en función de los elementos intersticiales minoritarios que contiene cada una de las aleaciones de titanio en cuestión. Cuanto mayor es el grado, mayor es la cantidad de 
elementos intersticiales presentes en la aleación y mayores son las propiedades significativas. Por tanto, al aumentar el grado, con él aumenta también la resistencia mecánica y disminuye la ductilidad y la resistencia a la corrosión $[22,26]$.

La Tabla I ilustra la composición química ( $\%$ en peso máximo), de acuerdo a los parámetros internacionales, para aquellos productos en barra de los cuatro grados de titanio utilizables en aplicaciones biomédicas:

\begin{tabular}{|l|l|l|l|l|l|}
\hline & N & C & H & O & Fe \\
\hline Ti c. p. Grado I & 0.03 & 0.08 & 0.015 & 0.18 & 0.20 \\
\hline Ti c. p. Grado II & 0.03 & 0.08 & 0.015 & 0.25 & 0.30 \\
\hline $\begin{array}{l}\text { Ti c. p. Grado } \\
\text { III }\end{array}$ & 0.05 & 0.08 & 0.015 & 0.35 & 0.30 \\
\hline $\begin{array}{l}\text { Ti c. p. Grado } \\
\text { IV }\end{array}$ & 0.05 & 0.08 & 0.015 & 0.40 & 0.50 \\
\hline
\end{tabular}

La Tabla II ilustra las propiedades mecánicas requeridas para los cuatro grados comerciales de titanio para aplicaciones biomédicas, según los parámetros internacionales:

\begin{tabular}{|l|c|c|c|}
\hline & $\begin{array}{l}\text { Resistencia a la } \\
\text { tracción mín. (Mpa) }\end{array}$ & $\begin{array}{l}\text { Límite eslástico al } \\
0.2 \% \text { mín. (Mpa) }\end{array}$ & $\begin{array}{l}\text { Elongación en 4 } \\
\text { D mín (\%) }\end{array}$ \\
\hline $\begin{array}{l}\text { Ti c. p. } \\
\text { Grado I }\end{array}$ & 240 & 170 & 24 \\
\hline $\begin{array}{l}\text { Ti c. p. } \\
\text { Grado II }\end{array}$ & 345 & 275 & 20 \\
\hline $\begin{array}{l}\text { Ti c. p. } \\
\text { Grado III }\end{array}$ & 450 & 380 & 18 \\
\hline
\end{tabular}




\begin{tabular}{|l|l|l|l|}
\hline $\begin{array}{l}\text { Ti c. p. } \\
\text { Grado IV }\end{array}$ & 550 & 483 & 15 \\
\hline
\end{tabular}

\section{- 2. La calidad superficial del implante}

Las propiedades fisicoquímicas y topográficas de la superficie del implante, las cuales son relevantes en el comportamiento biológico del titanio, son las que determinan su calidad superficial [20].

Esto resulta de particular interés, pues los primeros efectos de la implantación están ligados al modo en que la superficie del material sintético interactúa con el medio biológico. Tanto el contacto con la sangre, como la adhesión celular y la osteointegración están vinculados a las reacciones biológicas que el organismo y las células que lo conforman mantienen con dicha superficie [20, 22].

La Tabla III ilustra las propiedades y la información necesaria para describir la calidad de la superficie de una implante [27]: 


\begin{tabular}{|c|c|}
\hline Propiedad & Tipo de información \\
\hline \multirow[t]{2}{*}{ Composiciốn qúmica } & Composición atómica \\
\hline & Estado qúnicao de los elementos \\
\hline \multirow[t]{4}{*}{ Estructura/order/desorden } & Cristalinidad \\
\hline & Inclusiones \\
\hline & Vacantes \\
\hline & Ĺmites de gramo \\
\hline \multirow[t]{3}{*}{ Morfologi/textura/rugosidad/forma } & Forma 20 y ओ de los detalles srperfíciales \\
\hline & Área eppecitíca \\
\hline & Porosidad \\
\hline \multirow[t]{3}{*}{ Energia srperficial } & Mijabilidad \\
\hline & Ahsorción \\
\hline & Enegia sqperficial \\
\hline \multirow[t]{2}{*}{ Eléctrica } & Potencial de srperficie \\
\hline & Cargas sqperficiales \\
\hline \multirow[t]{2}{*}{ Mecánica } & Elasticidad/plasticidad \\
\hline & Tensiones residuales \\
\hline
\end{tabular}

Entre las propiedades fisicoquímicas de la superficie de titanio, cabe destacar, tal como se ha indicado, al estar este metal siempre recubierto por una capa de óxido, los agentes químicos y biológicos del organismo no interactúan directamente con aquél, sino con la capa de óxido en cuestión. Éste se trata de un material pasivo, lo cual implica una minimización de reacciones químicas producidas por la superficie del implante de titanio en el organismo [27].

En lo que refiere a las propiedades topográficas de la superficie del implante, su influencia es mucho más significativa. En efecto, es posible considerar que la topografía superficial es, entre las propiedades de la 
superficie del implante, la que más influencia tiene en la respuesta que el organismo tiene respecto a la intervención en cuestión [28].

Se volverá sobre este punto más adelante, pues necesita ser profundizado y detallado exhaustivamente a los fines del objetivo del presente documento. Cabe tener en cuenta, por ahora, que las modificaciones en la textura y rugosidad de la superficie del implante tienen vinculación directa con la osteointegración.

\section{- 3. El diseño macroscópico y dimensional del implante}

Existe una enorme variedad de diseños de implantes dentales endoóseos. La influencia del diseño resulta de fundamental importancia en lo que respecta a la transmisión de cargas en el transcurso el proceso de estabilización del hueso receptor. Cabe destacar que la osteointegración a largo plazo requiere de una repartición de cargas óptima [29].

Tal como se ha indicado más arriba, actualmente son los implantes de raíz roscados los que se emplean con mayor frecuencia, cosa que se debe al éxito de los mismos. En efecto, la estabilidad primaria del implante se ve favorecida por las roscas, lo que evita los micromovimientos indeseables que pueden contribuir negativamente a la osteointegración [29]. Además, las roscar contribuyen de manera positiva en la transferencia de cargas desde el implante hasta el hueso que lo circunda [30]. 


\section{- 4. El estado del hueso del receptor}

Respecto a este factor, cabe destacar que, desde la odontología, no es posible intervenir en el mismo. Es preciso, sin embargo, corroborar el estado en que el hueso se encuentra antes de la realización del implante, lo cual permite prever el posible fracaso o el posible éxito, en algunos casos, de la intervención [31].

\section{- 5. La técnica quirúrgica empleada}

Las técnicas quirúrgicas son de particular importancia en lo que respecta al éxito o fracaso de la implantación dentaria. Existen diferentes técnicas empleadas para la rehabilitación de pacientes édentulos. En lo respectivo a las diversas técnicas quirúrgicas utilizadas para la realización de implantes endoóseos, cabe destacar que todas ellas están orientadas a insertar los implantes en el hueso sin dañar en demasía los tejidos circundantes, en pos de que la estructura sane y se remodele con rapidez [32].

Existen ciertas consideraciones para poder lograr dicho objetivo. Por un lado, es necesario considerar que el hueso no resiste a una temperatura mayor a los $42^{\circ} \mathrm{C}$ durante más de un minuto, por lo que resulta necesaria la aplicación de una solución salina refrigerante durante el fresado [17]. Para que la osteointegración se asegure, es necesario que el lugar de inserción generado quirúrgicamente aproxime al hueso y al implante lo máximo posible [33]. Asimismo, es necesario que el cirujano tome las máximas precauciones asépticas, en pos de evitar el riesgo de infección perimplantaria [34].

Las diferentes técnicas quirúrgicas de colocación del implante pueden dividirse en tres modalidades [35]: 
- Técnica de implantes sumergidos o en dos etapas: En esta técnica los implantes son recubiertos, tras su colocación, con el mucoperióstio, para minimizar las cargas y los riesgos de infección. Sin embargo, cabe destacar que esta modalidad de implantación requiere de una segunda intervención para realizar la conexión entre los casquillos de prótesis.

- Técnica de implantes no sumergidos o en una etapa: El implante queda a través de la mucosa en una primera intervención. Sin embargo, es necesario que trascurra un tiempo de curación del tejido antes de iniciar la carga del implante.

- Técnica de implantes semisumergidos: Se trata de una técnica actualmente en desarrollo, pensada para evitar los inconvenientes que conllevan las otras dos.

Cabe destacar que los implantes pueden realizarse inmediatamente después de la extracción de los dientes, reduciendo así el tiempo de tratamiento (implantes inmediatos), o esperar un periodo que va desde las 3 a las 8 semanas para que los tejidos blandos sanen antes de realizar el implante o un periodo de entre 6 meses y un año para que el tejido óseo se remodele totalmente (implantes diferidos). 


\section{- 6. Las condiciones de carga del implante}

En pos de establecer la osteointegración cuanto antes y mantenerla durante el mayor tiempo posible, es necesario controlar las condiciones de carga del implante. Dicho control debe realizarse en tres fases: la fase de cicatrización, la fase de exposición del implante a las fuerzas de masticación y la fase de estabilización [32].

La primera fase, la de cicatrización, es la fase en la que se forma el nuevo hueso, adyacente al implante inmóvil. Se estima que dicho proceso dura aproximadamente entre tres y seis meses. Esto sucede únicamente si la osteointegración es exitosa [32].

Una vez expuesto el implante a las fuerzas de la masticación, el hueso formado recientemente se remodela. De este modo, cambian la magnitud, la dirección y la carga aplicada. De suceder esto de forma correcta, se asiste a un avance en la osteointegración [20,32].

Finalmente, pasados los dieciocho meses, se alcanza un estado de estabilidad. Esto implica la existencia de un balance de las fuerzas que actúan sobre el implante y la capacidad del hueso de remodelarse. Si esto sucede, la osteointegración se mantendrá adecuadamente [32].

Tradicionalmente se recomendaba cargar funcionalmente los implantes entre tres y cuatro meses, en lo respectivo a la mandíbula inferior, o seis y ocho meses, en lo respectivo a la mandíbula superior, es decir pasado el periodo de cicatrización. Sin embargo, se tiende a realizar cargas prematuras, es decir pocas semanas después de la implantación, o inmediatas, es decir apenas concluida la colocación del implante. Este tipo de cargas, no obstante, requiere de mayor control, pues una carga prematura excesiva puede provocar la formación de una cápsula gruesa de tejido blando rodeando su superficie de forma permanente, lo cual 
tiende a desestabilizar el implante, generando una serie de micromovimientos que contribuyen al fracaso del mismo [36].

- Reacciones histológicas en tejidos óseos

Como se ha afirmado muchas veces a lo largo de este trabajo, la osteointegración es fundamental en lo que respecta al éxito del implante. Por tanto, todo lo concerniente al tema de la reacción ósea refiere a la necesidad de una anquilosis funcional. Bränemark [37] fue el primero en plantear el concepto de integración completa del implante tras el trauma óseo que conlleva la preparación del lecho implantario, ligado al proceso de regeneración ósea. Éste, tiende a darse, en un organismo sano, aun cuando el cuerpo extraño no está presente. La superficie rugosa de los implantes recubiertos de plasma de titanio podrían llegar a tener, de acuerdo a una serie de estudios clínicos, un efecto osteoinductivo.

Esta cuestión ha devenido de particular interés en los estudios histológicos orientados a determinar la reacción sugerida por el implante en el tejido óseo. Respecto a esto, Albrektsson [22] afirma que en cualquier trauma severo, ya sea éste de carácter físico, químico o de cualquier otra naturaleza, el tejido óseo cicatriza naturalmente, formando de forma irreversible una capa de tejido fibroso. Pero reconoce también que, como es de esperar, resulta necesario que la zona necrótica esté bien vascularizada para que esto suceda.

Es preciso notar que los implantes de superficies porosas la revascularización es más rápida que en lo que respecta a la utilización de implantes lisos. De este modo, la reabsorción y regeneración ósea tienen lugar en presencia de osteoblastos y osteoclastos activos, siendo el osteoide formado inicialmente reemplazado en el transcurso de pocas semanas por un tejido óseo laminar maduro. El proceso de cicatrización no deja de ser el mismo que se lleva a cabo cuando no hay ningún 
implante. Tras la realización de un procedimiento quirúrgico adecuado y el ajuste óptimo del implante, es posible notar, sin embargo, que cuando hay un implante, el hueso regenerado se deposita directamente sobre la superficie del mismo, posibilitando la osteointegración necesaria para que éste sea efectivamente exitoso [38].

En dicho proceso, se puede decir que el hueso sigue todos los contornos y hendiduras de la superficie de la cobertura de plasma de titanio, existiendo osteoblastos vitales que están en contacto directo con la superficie del implante. Asimismo, en las zonas expuestas a tensiones de carácter elevado, se ha demostrado que parte de la cobertura de polvo de titanio puede desprenderse del implante, pero no así el hueso del polvo de titanio. Esto da cuenta de la efectividad de la integración entre hueso y titanio [38].

Albrektsson repara en que la efectividad de la osteointegración es evidente si se piensa que para separar in vitro el implante de su cobertura de plasma es necesario una fuerza de al menos $90 \mathrm{~N} / \mathrm{mm}^{2}$. Asimismo, dicho autor nota que el espacio entre la capa de óxido de titanio y el tejido óseo mineralizado no alcanza a superar los 100 angstroms, siendo un angstrom equivalente a $10^{-7} \mathrm{~mm}$. Dicho espacio, además, se encuentra relleno de un material matriz, compuesto de proteoglicanos, es decir de complejos mucopolisacáridos [22].

De este modo, entonces, es posible afirmar que la efectividad de la anquilosis funcional entre el implante y el hueso reside en el microanclaje de éste en el plasma del titanio. Esto ha sido corroborado por diferentes experimentaciones, en las que, mediante técnicas de microscopía y nanomicroscopía se ha observado el anclaje anquilótico en cuestión [12, 22].

Sin embargo, es preciso notar que en las observaciones remitidas no se ha considerado el factor de la carga. Es posible imaginar que el influjo de las cargas oclusales puede llegar a ser altamente perjudicial en 
el proceso de osteointegración, convirtiéndose gracias a él el tejido que recorre la frontera entre el implante y el hueso en una suerte de ligamento periodontal. Sin embargo, cabe destacar, este fenómeno no se ha observado jamás. La impresión contraria, mediante la cual es posible asegurar mejoras en la osteointegración a medida que pase el tiempo del implante, es, por el contrario, la más difundida [12].

Existen diversas experiencias histológicas que demuestran claramente la formación de un anclaje directo al tejido óseo sin que exista intervención alguna del tejido blando. Dicho fenómeno no ha sido demostrado únicamente en el terreno de los implantes odontológicos, sino que también se ha puesto de manifiesto en la traumatología. Los implantes ortopédicos de titanio en otras partes del esqueleto han demostrado ser eficaces y, sobre todo, diversas experiencias clínicas han dado cuenta de la mayor efectividad de los mismos si su superficie es de carácter rugoso [12].

Asimismo, ha sido probado, tanto histológica como clínicamente, que aquellos implantes que transmiten una presión masticatoria directa al hueso equivalen, en lo respectivo a sus cualidades funcionales, a los dientes. Dicho fenómeno es aplicable a dos planos diferentes y fundamentales en lo que respecta a la recuperación odontológica: por un lado, a las magnitudes de las fuerzas masticatorias soportadas; por el otro, a las experiencias subjetivas de los pacientes. A pesar de la ausencia de la existencia de un ligamento periodontal, los pacientes manifiestan no sentir diferencias sustanciales entre sus dientes naturales y los implantes [12].

- La osteointegración y las superficies del implante

Los esfuerzos de los investigadores están centrados, en la actualidad, en mejorar los resultados de las implantaciones dentarias, ya 
sea a corto plazo como a largo plazo. Uno de los esfuerzos realizados por aquellos que abocan su investigación a dicho respecto, ha sido puesto en la innovación de las diferentes técnicas quirúrgicas posibles para realizar implantes dentales. Otro grupo de investigadores, en cambio, ha centrado su labor en la difusión de la implantología dentaria entre la comunidad de odontólogos, materializando sus investigaciones en dos tendencias diferentes [39].

La primera de dichas tendencias busca reducir los tiempos de curación. Para ello, reconocen los investigadores, es necesario conseguir la mayor estabilidad funcional del implante en el menor tiempo posible. Eso puede conseguirse, tal como se ha sugerido más arriba, mediante una mejor respuesta del tejido óseo [39].

Por otra parte, una segunda tendencia reside en posibilitar la colocación de implantes más cortos. Esto sucede porque los implantes cortos son más manejables y pueden emplearse para un mayor número de situaciones. Es por ello que, actualmente, existe la tendencia de fabricar implantes con menor superficie nominal, aunque capaces de alcanzar una estabilidad mecánica satisfactoria a largo plazo [39].

De acuerdo con una serie de estudios clínicos, orientados de acuerdo a estas dos tendencias [18, 41], existe cierta relación entre la rugosidad de las superficies de titanio de los implantes y la osteointegración que garantiza su éxito a corto y a largo plazo. Como se ha indicado previamente [22], la calidad topográfica de la superficie del implante juega un rol primordial en lo respectivo a su efectividad. Esto significa que los posibles cambios en la rugosidad de dicha superficie son poseedores de una influencia significativa entre todos aquellos eventos que conducen a la aceptación del implante por parte del huésped.

En efecto, tanto la adsorción de proteínas, así como la mineralización de la matriz extracelular que conforma el tejido óseo, la adhesión, la proliferación y la diferenciación de los osteoblastos y de los 
osteoclastos, se ven íntimamente influenciados por la topografía de la superficie del implante [41]. Del mismo modo, la rapidez de los procesos de curación y la eficacia biológica del proceso de osteointegración que éstos implican [40].

Cabe destacar que, de acuerdo a ciertos estudios recientes [42], el movimiento en la interfaz presente entre el hueso y el implante perjudica a la efectiva curación del hueso. Dicho movimiento puede ser reducido significativamente si se aplica un implante dotado de una efectiva topografía superficial, promoviéndose así una mejor fijación a largo plazo.

Por tanto, no cabe duda de que la calidad topográfica de la superficie del implante juega un rol decisivo en su correcto funcionamiento. Es necesario, de este modo, considerar este factor como un factor fundamental para garantizar el éxito de la intervención odontológica.

Los estudios referidos, de carácter clínico, ofrecen evidencias suficientes para considerar que es necesario controlar el tipo de rugosidad del implante en pos de generar respuestas biológicas adecuadas mediante la intervención. Otros estudios, posteriores [30, 42, 43], dan cuenta comparativamente de las ventajas presentes en los implantes de superficies microrrugosas. En efecto, estos últimos demuestran un alcance más rápido de la osteointegración, dan cuenta de la existencia de mayores porcentajes de superficie ósea en contacto directo con el implante y de un aumento en la resistencia de aflojamiento, pues necesitan de una mayor torsión para ser extraídos.

Antes de continuar con el desarrollo de este trabajo, es preciso dar cuenta de algunas cuestiones conceptuales y terminológicas. Es posible definir topografía como la morfología o configuración de una superficie. Respecto a la misma, cabe destacar que existen dos propiedades topográficas básicas. La primera, es la rugosidad. La segunda, la textura. 
La textura da cuenta de una amplia serie de configuraciones que se disponen deliberadamente sobre la superficie. Entre dichas configuraciones se encuentran los surcos, los cantos, las crestas, las colinas, los poros y los valles, etc., dispuestos de forma regular y con determinas dimensiones y distribuciones previamente definidas. Los mecanismos de disposición no arbitraria de los mismos involucran procesos mecánicos, sintetizaciones y grabados de la superficie.

Por otra parte, la rugosidad da cuenta de las irregularidades y asperezas de diferente longitud de onda que puede superponerse a la forma de una determinada pieza. Algunos estudiosos [45, 46] dividen dichos caracteres irregulares en tres categorías diferentes:

- Rugosidad: En esta categoría están incluidas las irregularidades de corto alcance dentro del espacio superficial, así como la textura de la superficie inherente al proceso de fabricación de la pieza.

- Ondulación superficial: Se trata de aquellas irregularidades en la superficie cuya amplitud variable es mayor a la de las que constituyen rugosidad.

- Error de forma: Se trata de una desviación de la forma nominal de la pieza. 
El análisis en cuestión se centra en la rugosidad. Los implantes, tradicionalmente, fueron diseñados con superficies lisas. En la actualidad, de acuerdo a los estudios referidos, se estima que las piezas con superficie rugosa son más efectivas para garantizar el éxito del implante.

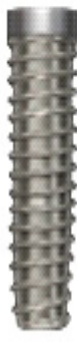

Lisa

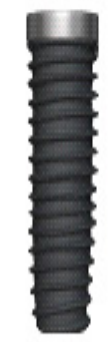

Texturada

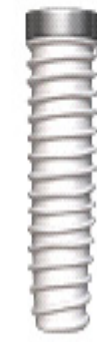

Hidroxiapatita

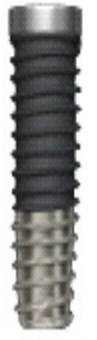

Combinación de superficie lisa y texturada

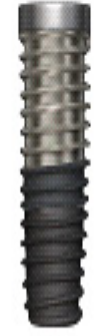

Combinación de superficie Implante Texturado lisa y texturada

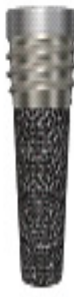

3D Innova

Fig. 18. Vista macroscópica de implantes con superficies de diferente rugosidad

(Fuente: http://www.1888implant.com/spanish/dentalimplants.html).

\section{- A. Superficies lisas y rugosas}

Usualmente se denomina superficies lisas a aquellas superficies cuyo aspecto macroscópico se presenta como liso y brillante. Sin embargo, es preciso considerar que las superficies lisas no son en realidad tan lisas como parecen. $\mathrm{Si}$ son observadas microscópicamente, las superficies lisas son poseedoras de una serie de circunferencias microscópicas paralelas entre sí y perpendiculares respecto al eje largo de los implantes. Cabe destacar que, sin dichas 
circunferencias, no podría llevarse a cabo el proceso de osteointegración [47].

Resulta preciso considerar que la denominación que reciben las superficies lisas de los implantes está orientada a fines didácticos y ligada al aspecto macroscópico de la superficie. Pero, en realidad, dichas superficies no están exentas de una determinada textura o porosidad de carácter topográfico a nivel microscópico. En efecto, a las referidas circunferencias, es preciso agregar una serie de microsurcos superficiales de patrón regular, que miden entre $4 \mu \mathrm{m}$ y $10 \mu \mathrm{m}$ de altura y $2 \mu \mathrm{m}$ y $8 \mu \mathrm{m}$ de diámetro, producto del proceso de corte del metal [47].

La Figura 19 muestra la superficie lisa de un implante observada microscópicamente. En ella se pueden ver claramente las microirregularidades existentes sobre la superficie del cuello del implante, ligadas al proceso de mecanizado del titanio, así como rayas microscópicas causadas presumiblemente por el efecto abrasivo de micropartículas despegadas de las curetas: 


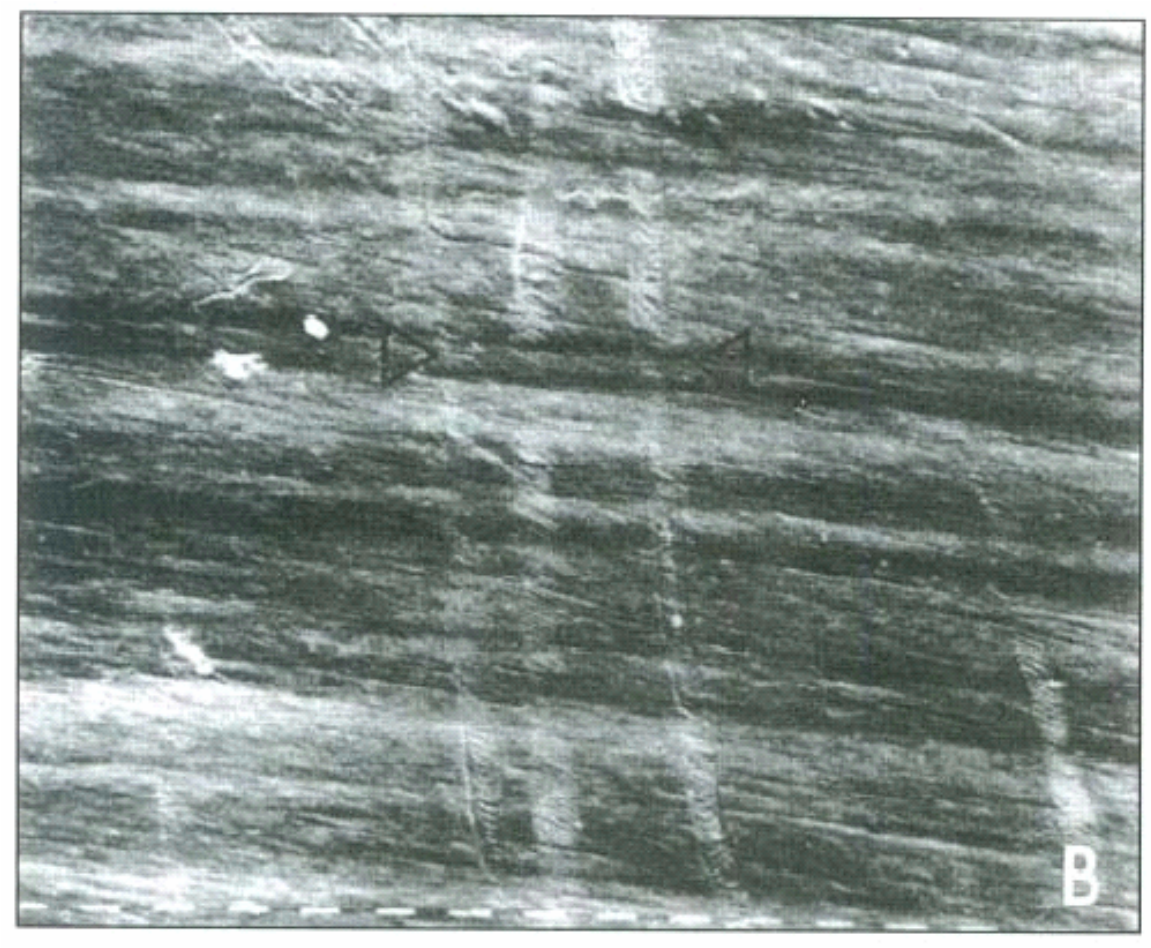

Figura 19. Superficie lisa de un implante observada microscópicamente

(Fuente: http://scielo.isciii.es/scielo.php?pid=S1699$\underline{65852000000200003 \& \text { script }=\text { sci arttext) }}$

Tradicionalmente, los implantes de superficie lisa son los primeros en ser empleados por los odontólogos. Existen diferentes estudios capaces de probar la alta tasa de éxito con implantes osteointegrados en la restauración de pacientes edéntulos parciales o totales, realizados con piezas de titanio de superficie lisa [7].

Sin embargo, y a pesar del éxito que estos implantes han logrado, estudios recientes indican que existe un incremento significativo en la afinidad de los osteoblastos y una más rápida formación de contacto directo con el hueso a las superficies con un grado moderado de rugosidad [48, 49]. 
En efecto, es sabido que la osteointegración se produce de forma diferenciada en los implantes de superficie lisa que en los de superficies rugosas. En lo que respecta a estas últimas, se sabe que la formación del hueso regenerado ocurre directamente sobre ellas, mientras que los implantes de titanio puro con superficie lisa son osteointegrados gracias al crecimiento del hueso desde los tejidos adyacentes [50].

Es por ello que, en la actualidad, gran parte del número de investigaciones ligadas al desarrollo de la implantología dentaria está orientada a la evaluación de las superficies rugosas, así como a las técnicas de tratamiento superficial pertinentes para alcanzar la rugosidad justa en pos de producir una osteointegración adecuada.

Es preciso preguntarse si la clasificación superficies lisas/superficies rugosas es adecuada. En efecto, si se considera lo dicho acerca de la rugosidad de las superficies lisas, resulta pertinente pensar que dicha clasificación es confusa. En efecto, la misma está elaborada a partir de la observación macroscópica.

En pos de caracterizar la rugosidad superficial implantaría, entonces, de una forma adecuada, que no se preste a la confusión, es preciso aclarar que ésta puede ser categorizada macroscópicamente, microscópicamente y nanoscópicamente [3]. Así, en términos de macrorugosidad, según la cual la escala de rugosidad superficial está ligada directamente a la de la geometría del implante, la clasificación superficies lisas/superficies rugosas conserva un determinado valor descriptivo. Pero no sucede lo mismo en función de la micro y la nanorugosidad.

La primera es definida en el rango de 1 a $10 \mu \mathrm{m}$, dentro del cual se maximiza el engranaje entre el hueso mineralizado y la superficie implantaria. El uso de superficies provistas con topografías nanométricas es, en cambio, de aparición reciente e involucra 
materiales con un rango dimensional entre 1 y $100 \mathrm{~nm}$. En pos de caracterizar correctamente el proceso de osteointegración, en el cual la superficie texturizada aumenta la energía superficial y con ello la mojabilidad a la sangre y la adhesión celular, y facilita el depósito de fibrina, factores de crecimiento y matriz proteica, es preciso adoptar dicha escala $[3,6,7]$. Es por ello que se considera la necesidad de adecuar los conceptos topométricos para caracterizar la osteointegración implantaría y determinar el grado de rugosidad de las superficies implicadas en ella, a la escala nanométrica. Esto implica, asimismo, clasificar la superficie de los materiales implicados no en función de si son lisos o rugosos macroscópicamente, sino de acuerdo al tratamiento que éstos reciben y que influye directamente sobre la nanorugosidad, no siendo percibido a nivel macro o microscópico.

\section{- B. Tratamiento de las superficies}

Tal como se ha visto, a nivel nanométrico es posible comprender que las superficies lisas no son en verdad del todo lisas. Dicha denominación, en efecto, es producto de su apariencia macroscópica. Sin embargo, cabe distinguirlas de las llamadas superficies rugosas, pues el efecto clínico de ambas difiere considerablemente, sobre todo en lo que respecta su integración con el hueso.

Fernández Boderau, Bassone y Naldini (2009) [47] revisan dicha clasificación. Para dichos autores, las superficies de los implantes dentales pueden ser clasificadas como lisas y texturizadas. Las primeras son, de acuerdo a la clasificación revisada, aquellas superficies que no presentan ningún tipo de tratamiento adicional en pos de modificar su rugosidad. Por tanto, el titanio se presenta a nivel macroscópico como una superficie pulida y brillante, si bien microscópicamente presenta una determinada rugosidad. 
El segundo grupo de superficies de implantes consiste en la reunión de todos aquellos que presentan superficies que han sido tratadas para lograr rugosidades y texturas en mayor o menor grado. Los autores en cuestión dividen a este grupo en dos grupos distintos: por un lado, están las Ilamadas superficies texturizadas por sustracción; por el otro, las superficies texturizadas por adición [47].

Las superficies texturizadas por sustracción se producen a partir del retiro de materia o sustracción física, química o ambas de las partículas metálicas que constituyen la superficie de titanio de los implantes. Los tratamientos aplicados para lograr estos tipos de superficie son los siguientes [47]:

- Tratamientos ácidos: El tratamiento o grabado por ácido está orientado al desprendimiento de las partículas metálicas de la superficies del implante mediante la inmersión de éstas en fuentes ácidas. Los ácidos mayormente empleados para este proceso son el ácido fluorhídrico, el ácido sulfúrico y el ácido clorhídrico. El tratamiento con ácido tiende a dejar áreas de mayor corrosión en los picos y valles de las ranuras que deja la fabricación de la superficie. Las ventajas de este método residen en el hecho de que a partir de él es posible controlar el grado de porosidad de la superficie, así como el de permitir un adecuado método para la limpieza de las impurezas no deseadas, generadas durante la manufactura del implante. La técnica de doble grabado es aquella que emplea ácido sulfúrico y ácido clorhídrico y permite una superficie rugosa de carácter uniforme, dotada de picos y depresiones con una profundidad que oscila entre 1 y $2 \mu \mathrm{m}$. Éstos posibilitan una apropiada retención del coágulo en la formación de la matriz ósea. 
- Tratamiento con chorro de partículas: También denominado arenado, este tipo de tratamiento consiste en chorrear partículas diversos materiales dotados de una duraza mayor a la del titanio, como ser el óxido de aluminio, el óxido de titanio, el sílice y la hidroxipatita, sobre la superficie del implante. Al colicionar sobre ésta, generan estas partículas una serie de depresiones irregulares, las cuales se denominan macrorretenciones. Sin embargo, este método posee una gran desventaja, pues no se puede producir mediante él una superficie de carácter homogéneo.

- Tratamiento por chorro de partículas asociado al tratamiento ácido: Para obtener macrorretenciones, propias del arenado, y microretenciones, propias del tratamiento ácido, se han asociado ambos procedimientos. Se ha determinado que las irregularidades morfológicas resultantes de esta combinación pueden llegar a ser harto provechosos en el proceso de osteointegración, pues podrían incentivar el anclaje inicial de los osteoblastos.

- Tratamiento con rayos láser: El tratamiento por láser posee la ventaja de que permite controlar la profundidad, el tamaño, la dirección y la orientación de las rugosidades. Asimismo, al no intervenir otras sustancias químicas, evita la contaminación del material bioinerte.

Las superficies texturizadas por adición son aquellas que se producen mediante una síntesis por adición de partículas esféricas de polvo, cuyas dimensiones oscilan entre los 44 y los $150 \mu \mathrm{m}$, metálico de titanio o cerámico de hidroxiapatita al núcleo de metal del cuerpo del 
implante. Cabe destacar que estos métodos aumentan la superficie porosa del área total de la osteointegración, así como la adhesión biomolecular. Los tratamientos más frecuentes para lograr estas superficies porosas son [47]:

- Tratamiento de plasma con spray de titanio o de hidroxiapatita: Es un procedimiento que se lleva a cabo en altas temperaturas. El conjunto de partículas se funde parcialmente en las áreas en que éstas son propulsadas mediante un plasma o gas ionizado, soldándose en la superficie de titanio. Los resultados son positivos, pues mejoran la biocompatibilidad, pero el gran problema reside en el hecho de que las piezas del implante y los depósitos de partículas, al presentar propiedades mecánicas diferentes, trabajan en módulos de elasticidad diferentes. Esto genera poca estabilidad de adherencia $y$, por tanto, poca durabilidad, pues pueden desprenderse durante el proceso de masticación.

- Tratamiento con oxidación anódica o anodizado: Se denomina anodizado a un proceso electroquímico de pasivación, que está orientado a incrementar el espesor de la capa de óxido de las piezas metálicas. En el caso del titanio, el espesor de la capa de óxido aumenta, en el lapso de un minuto, tras este proceso, de 10 A a $100 \mathrm{~A} \mathrm{y}$, luego de un tiempo breve, a $2000 \mathrm{~A}$. Cabe destacar que este tratamiento logra superar las dificultades que conlleva el tratamiento de plasma con spray.

- Tratamiento de deposición asistida por haz iónico: Este tratamiento consiste en el recubrimiento de la superficie a partir del bombardeo 
de una composición adecuada de hidroxiapatita mediante un haz de iones. Dicha composición se deposita en forma de capa, recubriendo la superficie metálica con un espesor nanométrico.

\section{- C. Técnicas para medir la rugosidad}

La importancia del conocimiento de la graduación de rugosidad de las diferentes superficies de los implantes reside en el hecho de que ésta tiene influencia directa en los procesos de osteointegración. Como se ha indicado, una rugosidad baja puede dificultar o retrasar dicho proceso. Asimismo, cabe considerar que una rugosidad excesivamente alta puede ser también ella perjudicial en el éxito de los implantes, pues, en términos generales, el pulido de una superficie está orientado a disminuir la fricción de la misma al estar en contacto con otra, reduciéndose así el fenómeno de desgaste y la corrosión de los materiales [51]. Por tanto, resulta de particular interés poder cuantificar la rugosidad del titanio o sus aleaciones empleadas para la realización de los implantes odontológicos, en pos de obtener los resultados deseados.

Cabe aclarar que, aunque la fricción tiende a inducir al desgaste de los materiales, también permite la sujeción de los objetos, evitando el resbalamiento de los mismos. Asimismo, a escala molecular, la rugosidad puede ser considerada como un factor biológico, pues afecta considerablemente el modo en que se adhieren las diferentes superficies [51].

Topográficamente es preciso hablar de superficies estocásticas y superficies determinísticas. Las primeras son de carácter aleatorio y su grado de rugosidad deriva, no de un proceso direccionado, sino del rompimiento o desgaste de la superficie [51]. Cuando se hizo alusión al hecho de que mismo las superficies lisas son poseedoras de una 
determinada rugosidad a nivel microscópico, quedó claro que dicha rugosidad es de carácter aleatorio.

Las superficies deterministicas, en cambio, son aquellas que resultan de procesos mecánicos de fabricación o de procesos químicos y están realizadas adrede [51].

Es preciso reconocer diferentes métodos y técnicas de medición de la rugosidad. El perfilómetro es, quizás, el equipo más frecuentemente utilizado para dichos fines. Este aparato permite medir la RMS rugosidad y la rugosidad promedio. Se trata de una fina punta de contacto con la superficie en cuestión, que se encarga de realizar un barrido controlado en línea recta. Mediante dicho barrido se identifican las variaciones de alturas, las cuales se convierten en señales eléctricas, susceptibles a ser graficadas o registradas [51].

Existen, sin embargo, otros equipos que difieren del perfilómetro y son aptos para medir la rugosidad. Éstos tienen la capacidad de, no sólo cuantificar la rugosidad, sino también de cualificarla, lo cual permite un análisis más exhaustivo de la rugosidad a mensurar [51].

Para clasificar los equipos que miden la rugosidad de las superficies, generalmente se los divide en dos grandes grupos: por un lado, están los instrumentos de contacto; por el otro, los equipos de no-contacto [51].

El perfilómetro, como se ha indicado, es un equipo de contacto. Otro equipo de contacto frecuentemente empleado es el microscopio de fuerza atómica (AFM). Éste opera como un perfilómetro de resolución sub-nanométrica, lo cual permite clasificar la rugosidad con una enorme precisión. En efecto, las longitudes de muestreo máximas con resolución nanométrica que este aparato puede permitir alcanzan los $100 \mathrm{~nm}[51]$. 
Asimismo, cabe destacar que el microscopio de fuerza atómica puede operarse en modo sin contacto. El resto de los equipos de nocontacto suelen ser de carácter óptico y se basan en cambios de enfoque de luz monocromática que guardan una relación de correspondencia con las diferentes alturas existentes en la superficie. Entre dichos instrumentos, de menor precisión, se encuentra el llamado comparador óptico.

\section{- D. Microscopía de fuerza atómica (AFM)}

El microscopio de fuerza atómica es la evolución del llamado microscopio de efecto túnel (STM). EI STM consiste en una pequeña punta metálica que se aproxima a la superficie del material a analizar a una distancia de $1 \AA$, en pos de aplicarle una diferencia potencial de $10^{-2}$ $\checkmark$ para establecer, por efecto túnel, una corriente eléctrica de $\sim 1 \mathrm{nA}$. Gracias a dicho procedimiento es posible obtener imágenes de carácter topográfico de la superficie de la muestra en cuestión sin la necesidad de emplear campos eléctricos externos de carácter intenso. Esto permite observar la topografía de la superficie con una resolución atómica [52].

La extensión más directa del STM, dotada de una resolución aún más precisa, es el AFM (Fig. 20 y Fig. 21). El mismo fue diseñado a mediados de los años ochenta por Gerd Binning y Christof Gerber para poder examinar la topografía atómica de superficies aislantes, pegando una punta muy pequeña de diamante en el extremo de una pequeñísima tira de papel de oro. Poco tiempo más tarde, el dispositivo en cuestión fue modificado y mejorados por Albrecht [52]. 


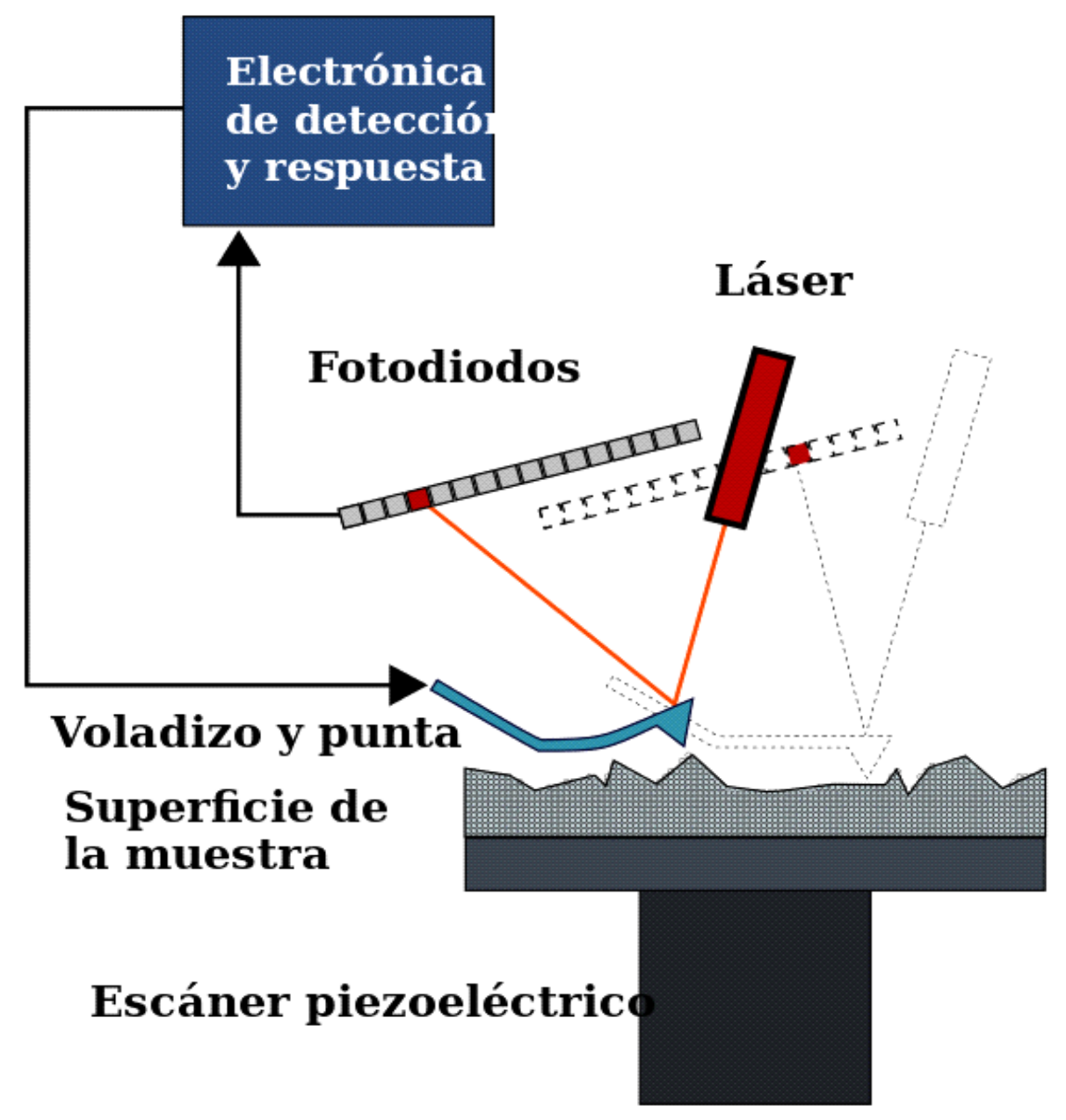

Fig. 20. Partes del microscopio de fuerza atómica (Fuente:

http://es.wikipedia.org/wiki/Microscopio de fuerza at\%C3\%B3mica\#medi aviewer/File:Microscopio de fuerza atomica esquema v2.svg)

EI AFM puede ser clasificado, en función de la interacción de la punta y la superficie de la muestra, como modo repulsivo o de contacto y modo atractivo o de no-contacto. Sus principios básicos son harto sencillos. La pequeña punta barre automáticamente sobre la superficie de la muestra a través de un mecanismo de retroalimentación. Dicho mecanismo posibilita que unos scanners piezoeléctricos mantengan la punta en interacción con la superficie en cuestión a fuerza constante, en pos de obtener información sobre las alturas, o a altura constante 
respecto a la superficie, en pos de obtener información sobre la fuerza [52].

Las puntas están fabricadas, actualmente, por lo general con silicio o nitruro de silicio y se extienden hacia abajo desde el final de un cantilever. Las puntas, junto con el cantilever, constituyen los cabezales. Es allí donde se ubica la muestra. Asimismo, los cabezales poseen un sistema óptico de detección en el cual incide un haz de láser que es reflejado por al cantilever $[52,53]$.

Sobre la parte trasera del cantilever reflectante se focaliza un láser de diodo. En función de la deflexión sufrida por el cantilever, mientras la punta barre moviéndose de arriba hacia abajo según el contorno de la superficie, el haz de láser refleja con un determinado ángulo, incidiendo en una posición concreta de un fotodiodo de dos o de cuatro elementos. Un fotodetector es el encargado de medir la diferencia de intensidad de luz. Manteniéndose la punta a una fuerza constante, mientras realiza el barrido sobre la superficie, un transductor piezoeléctrico posibilita la desviación de la altura. Así, es posible obtener imágenes de altísima resolución y de carácter tridimensional [52].

Cabe destacar que en ciertos casos la resolución de STM es mejor que la del AFM. Esto sucede gracias a la dependencia exponencial de la corriente túnel con la distancia. En efecto, el AFM posee una dependencia fuerza-distancia mucho más compleja que el STM debido a la forma de la punta y a la fuerza de contacto. Sin embargo, el STM sólo puede ser aplicado a muestras conductoras, siendo el SFM mucho más versátil. Además, a diferencia de lo que sucede en el STM, el voltaje y el espaciado entre la punta y la superficie de la muestra pueden controlarse independientemente, siendo ésta una gran ventaja para privilegiar el uso de éste por sobre el de aquél [52]. 


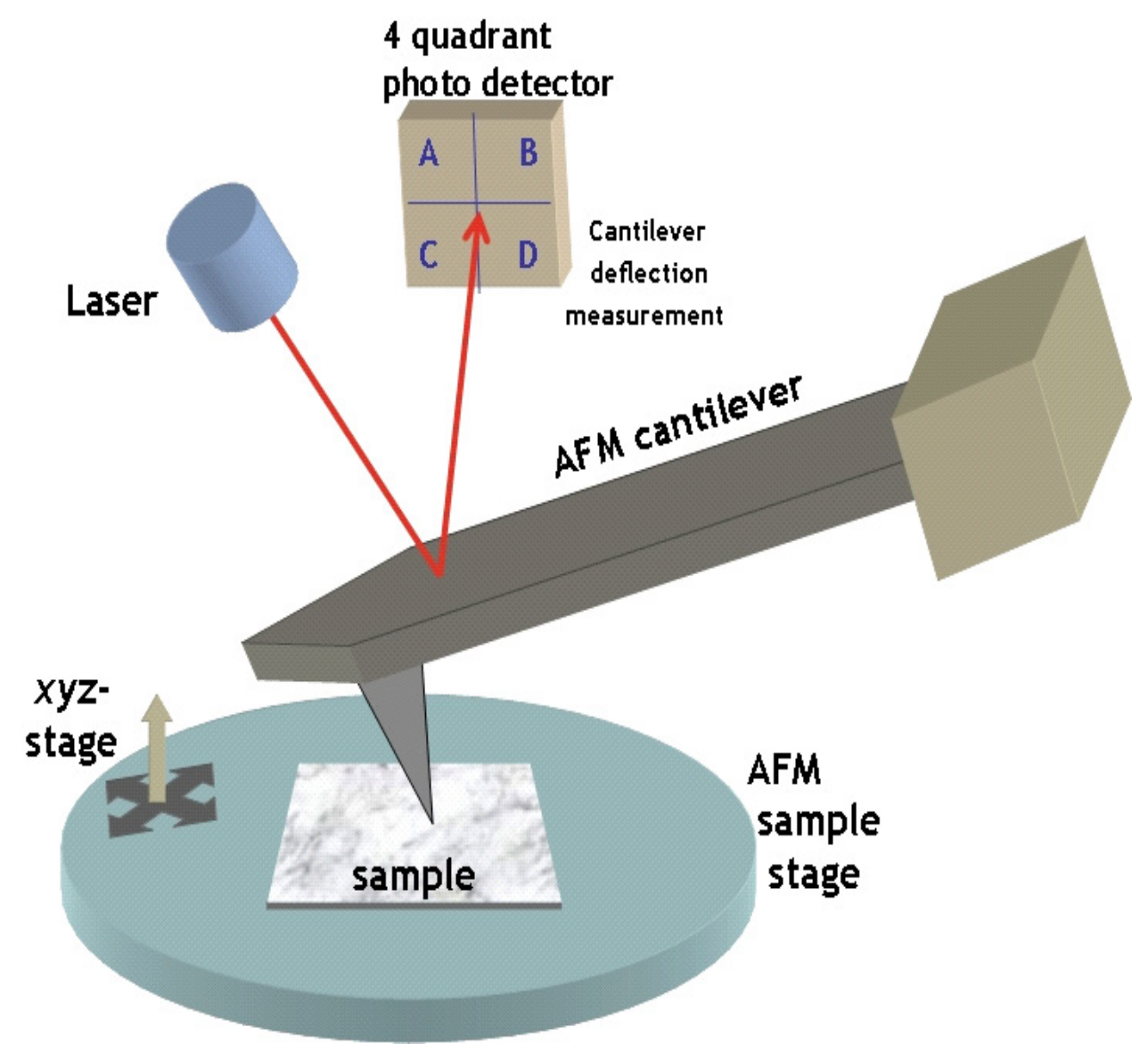

Fig. 21. Diagrama del microscopio de fuerza atómica.

(Fuente: http://opensource.org/).

\section{- E: Parámetros para medir la rugosidad}

Los parámetros empleados para la cuantificación de la rugosidad son aquellos que revelan la distribución estadística de las alturas presentes en la superficie de la muestra. Por tanto, deberán excluirse de dichas mediciones parámetros propios de la morfología de la superficie que no guardan vinculación directa con la variación topográfica de las alturas de la misma en un sentido estricto, como ser la inclinación, la curvatura o la ondulación periódica o aperiódica [51]. 
El siguiente dibujo (Fig. 22), muestra la textura de una superficie, indicando la diferencia entre la altura de la ondulación y la altura de la rugosidad. Esta última es la que debe ser tenida en cuenta para medir la rugosidad, la cual refiere a las desviaciones más pequeñas de la superficie y está determinada tanto por las cualidades del material como por el proceso a partir del cual se formó la superficie:

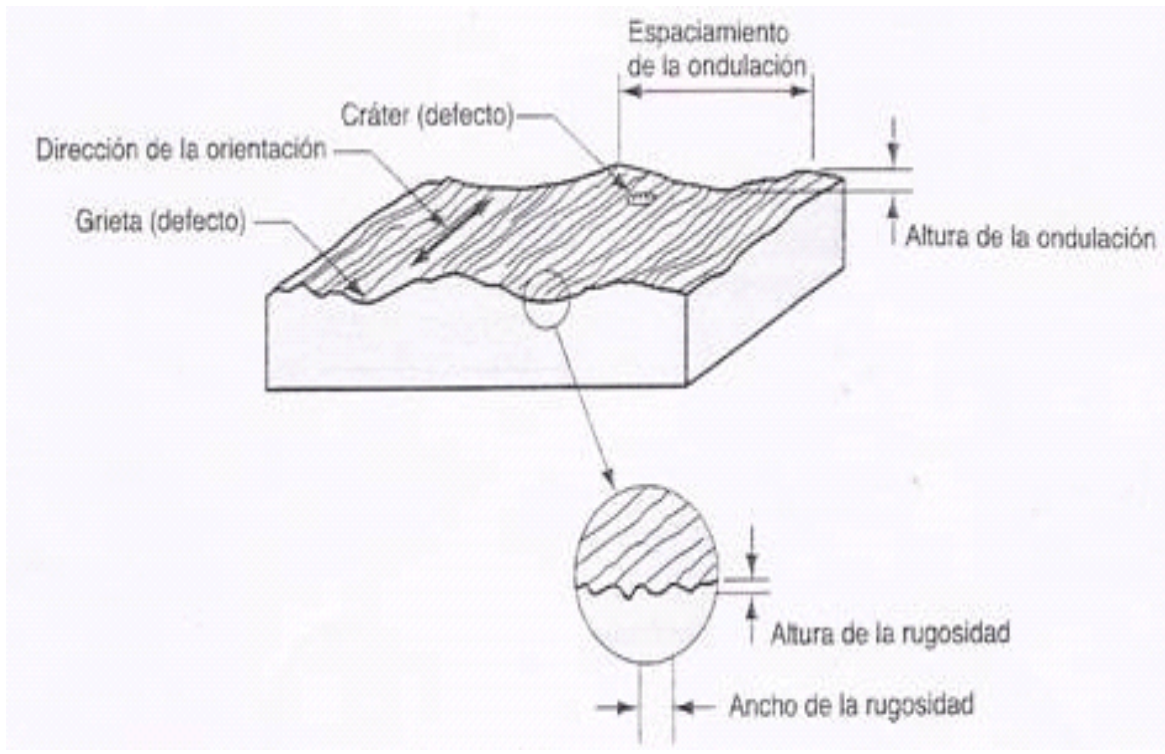

Fig. 22. Textura de una superficie

(Fuente: http://dibujotecnico09.blogspot.com.ar).

Los parámetros de rugosidad más utilizados para realizar las cuantificaciones en cuestión son los siguientes [51] (Fig 23):

- Rugosidad promedio (Ra): Se trata del promedio aritmético de los valores absolutos de las alturas medidas a partir de una línea central. Matemáticamente se define de esta manera:

$R a=1 / L \int_{0}^{L}|y(x)| d x$

En donde $L$ es la longitud de muestreo. 
- RMS rugosidad (Rrms): Representa el promedio de las desviaciones cuadráticas con respecto a la altura media. Se trata de la desviación estándar de la distribución estadística de las alturas, la cual equivale a la raíz cuadrada de la varianza respecto a la media.

- Rango (Ry): Consiste en la diferencia máxima de alturas en la longitud de muestreo.

- Altura de diez puntos (Rz): Se trata de la distancia promedio entre los cinco picos de mayor altura y los cinco valles de mayor profundidad presentes en la longitud de la muestra. 
$\mathrm{Ra}$

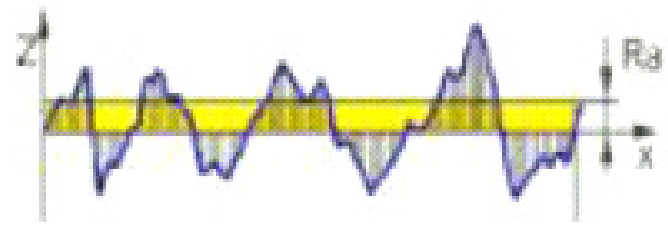

RSm

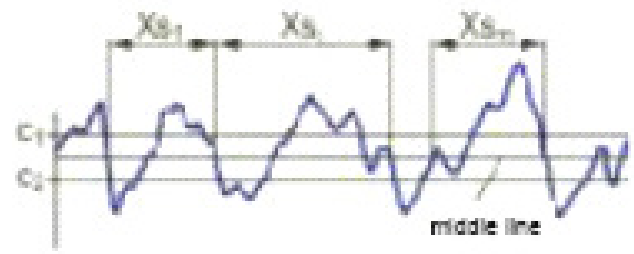

Rz

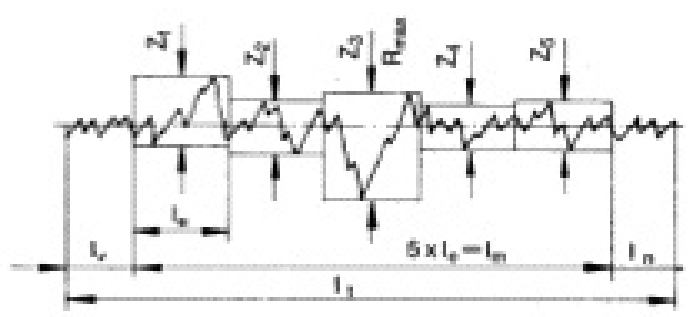

Fig. 23. Parámetros de rugosidad (Ra, Rrms, Rz).

(Adaptado de: http://www.measurecontrol.com/introduccion-a-larugosidad-i/). 


\section{- Capítulo 3: Hipótesis y objetivos}

\section{- Hipótesis}

"La Microscopía de Fuerza Atómica posibilita la caracterización y comparación nanométrica de diferentes tratamientos de superficie de titanio, para poder elaborar un modelo teórico que permita su ensayo clínico e investigación sustentados en las bases biológicas establecidas por la bibliografía".

- Objetivos

- Objetivo general

- Caracterizar nanométricamente las rugosidades de diferentes tratamientos de superficie de titanio mediante AFM.

- Objetivos específicos

- Comparar nanométricamente las rugosidades de diferentes tratamientos de superficie de titanio mediante AFM;

- Relacionar a través de un modelo teórico estas rugosidades con las bases biológicas establecidas por la bibliografía para eventuales ensayos clínicos e investigación. 


\section{- Capítulo 4: Diseño de la investigación}

\section{- Descripción}

Estudio observacional descriptivo con análisis de variables cualitativas y cuantitativas. Se estudiarán tres tipos de superficies de titanio para la realización de implantes dentales, una sin ningún tratamiento para modificar su rugosidad (lisa) y dos tratadas (una mediante un proceso de grabado por ácido y otra mediante un proceso de anodizado). A través de un AMF, se medirá la rugosidad de cada una de ellas considerando los siguientes parámetros de rugosidad:

- Altura máxima

- Altura mínima

- Altura promedio

- RMS Rugosidad.

\section{- Capítulo 5: Materiales y Métodos}

\section{- $\quad$ Muestras}

Las muestras utilizadas fueron 18 placas de titanio de 10 milímetros por 3 milímetros las que se agruparon en tres categorías según el tratamiento superficial a recibir:

- GRUPO A: titanio liso (sin tratamiento de superficie)

- GRUPO B: titanio con grabado ácido

- GRUPO C: titanio anodizado

- Preparación de las placas de titanio y modificación de sus superficies 
Se utilizaron como sustratos placas de titanio (KS-50, JIS tipo 2, Kobelco, Kobe, Japón) de pureza comercialmente disponible $(n=18)$ con un tamaño de 10 milímetros por 3 milímetros. Siguiendo la metodología descripta por Zareidoost et al. [8], estas muestras fueron pulidas con papel de arena de 600 grits y luego lavadas con $\mathrm{NaOH}$ a 40 vol \% y $\mathrm{HNO}_{3}$ a $50 \mathrm{vol} \%$ en baño ultrasónico para remover contaminantes. Luego fueron lavadas en agua deionizada para obtener un $\mathrm{pH}$ neutro $\mathrm{y}$ colocadas a temperatura ambiente en una solución de etanol $70 \mathrm{vol} \%$.

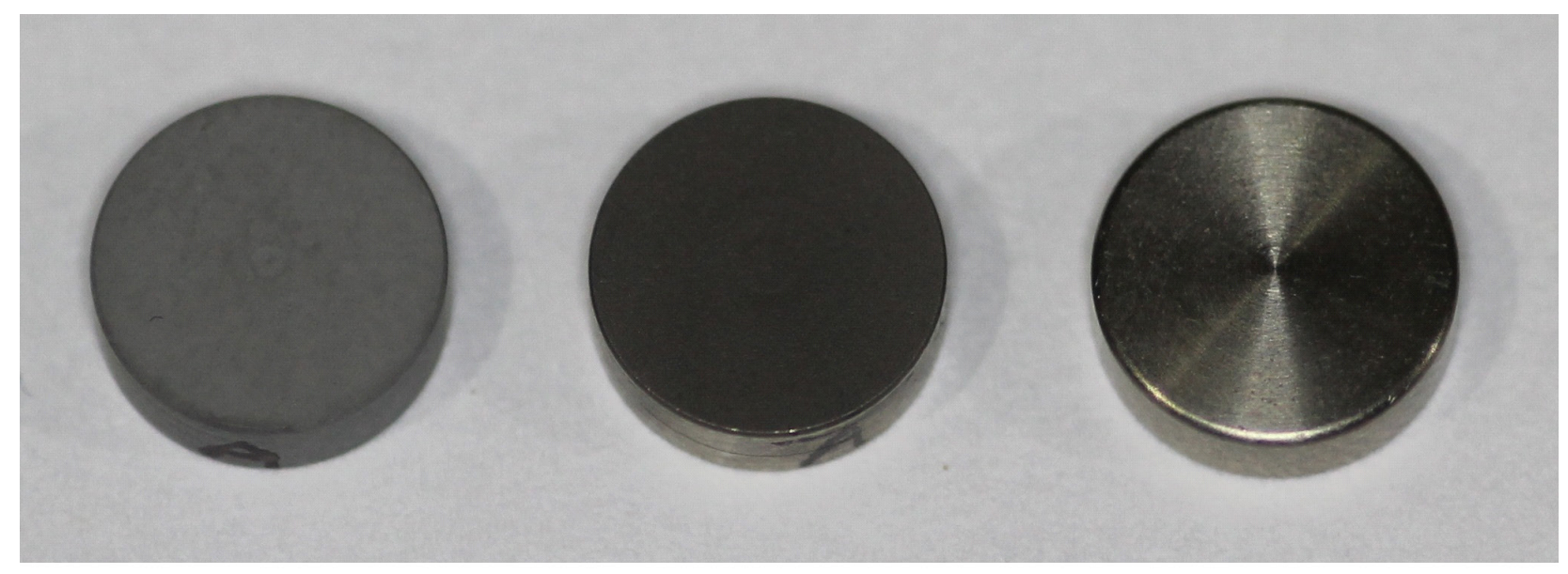

Fig. 24. Muestras de Titanio

Las 18 muestras fueron categorizadas en tres grupos:

- GRUPO A: en número de 6 (seis) muestras, no recibieron tratamiento superficial alguno y son las denominadas Lisas (Fig. 25). 


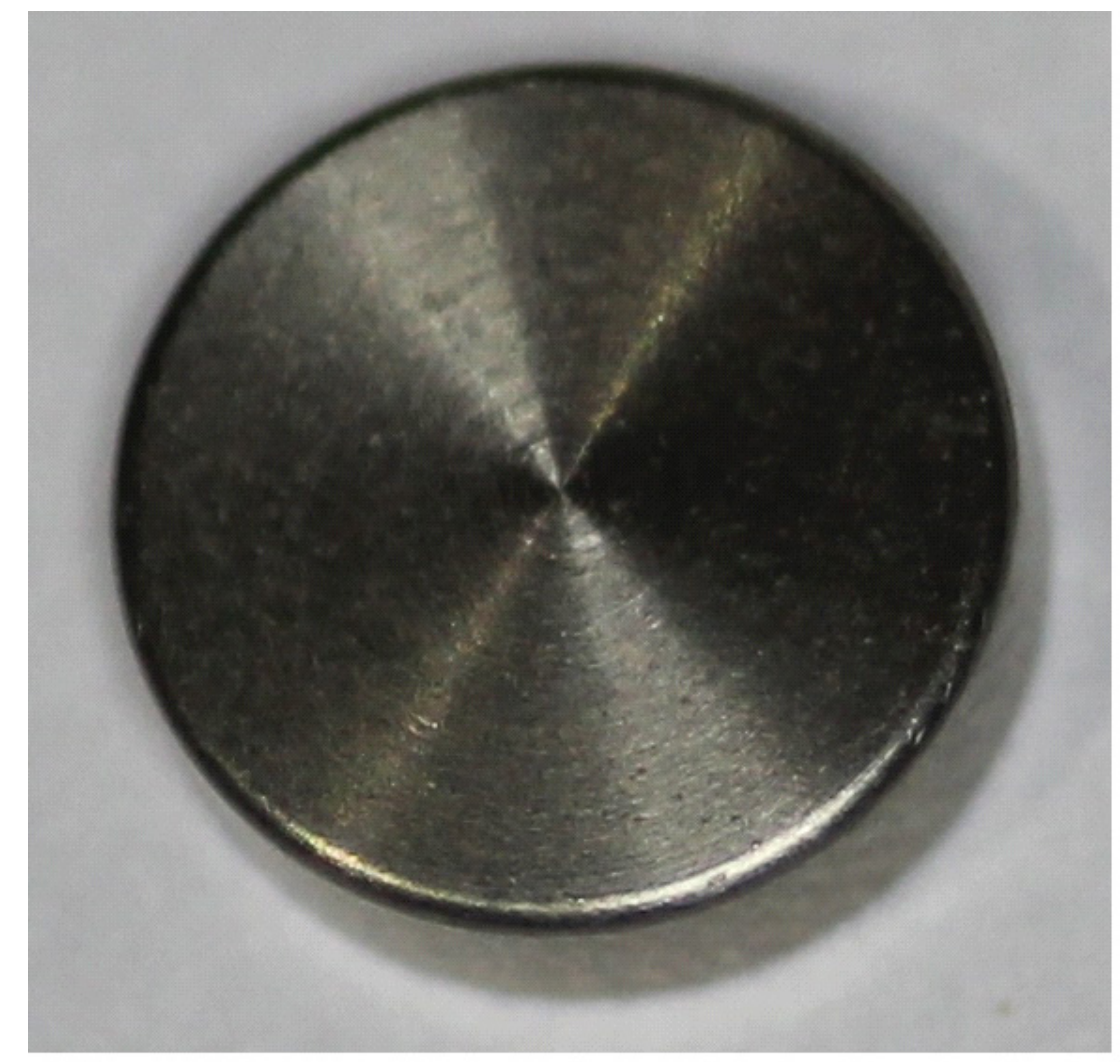

TITANIO SIN TRATAR

Fig. 25. Titanio sin tratar (superficie lisa)

- GRUPO B: en número de 6 (seis) muestras, recibieron tratamiento de grabado ácido consistente en granallada de 300 micrones de fosfato de calcio, Resorb blast media. Luego fueron expuestas a una mezcla bi ácida de ácido sulfhídrico y clorhídrico 10 molar durante 30 minutos (Fig. 26 y Fig. 27). 


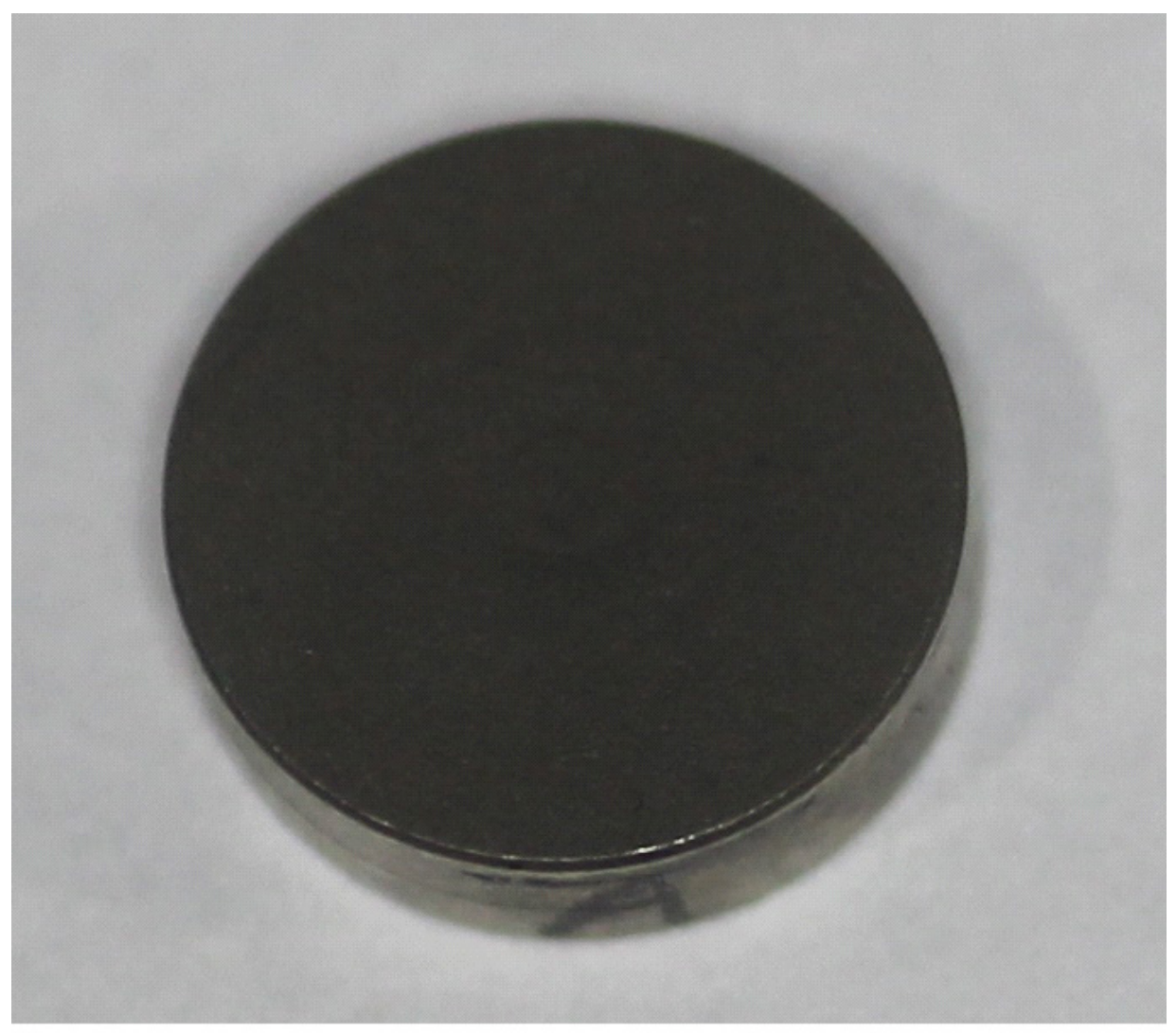

GRABADO ÁCIDO

Fig. 26. Titanio ácido grabado. 


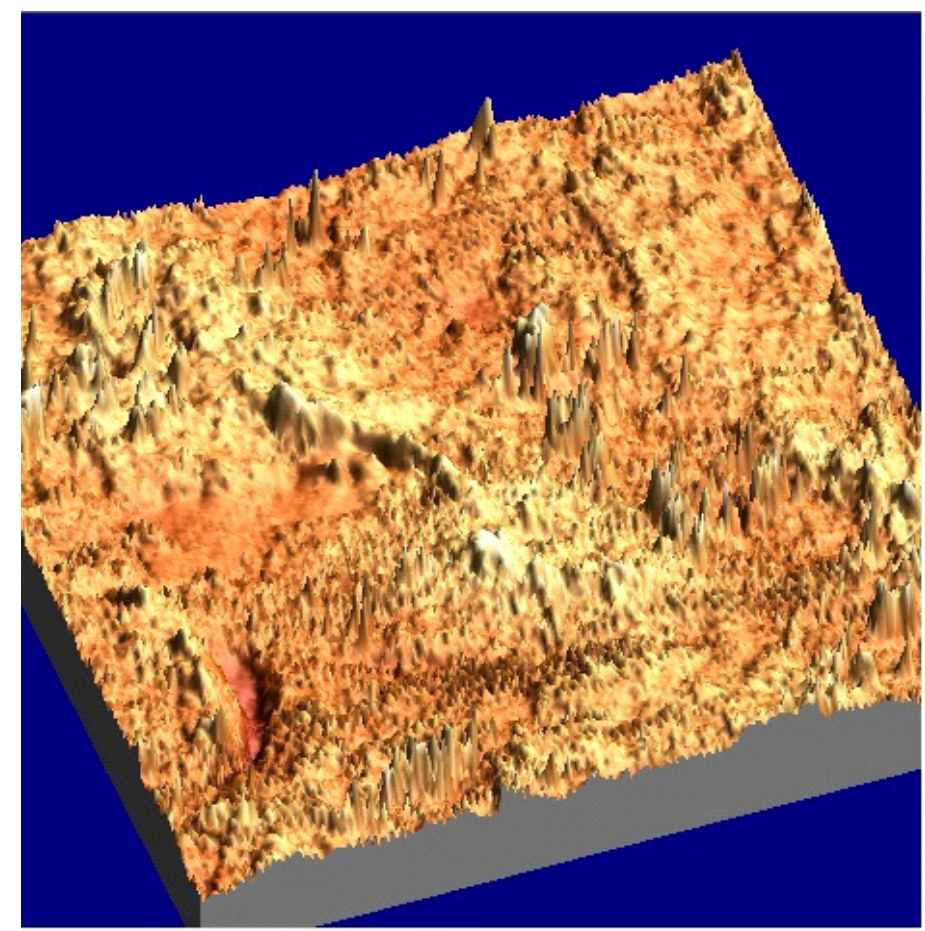

Fig. 27. Topografía de superficie de titanio grabada en ácido.

- GRUPO C: en número de 6 (seis) muestras, se les realizó anodización de electro deposición, con granallada de 300 micrones de fosfato de calcio, Resorb blast media. Luego se les realizó galvanización dentro de un electrolito rico en minerales ( $\mathrm{Ca}$ y $\mathrm{P}$ ) (Fig. 28 y Fig 29). 


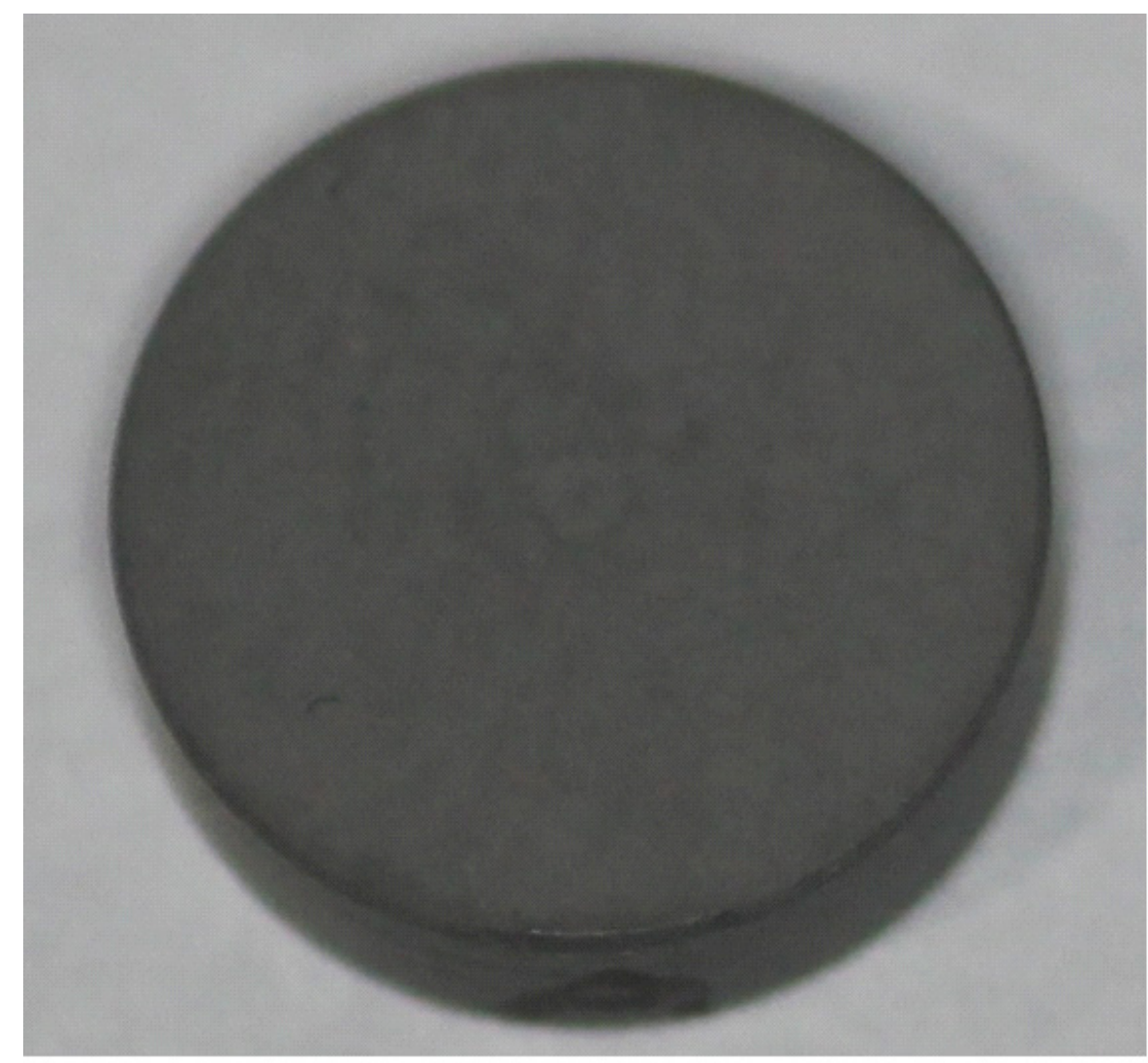

ANODIZADO

Fig. 28. Titanio anodizado. 


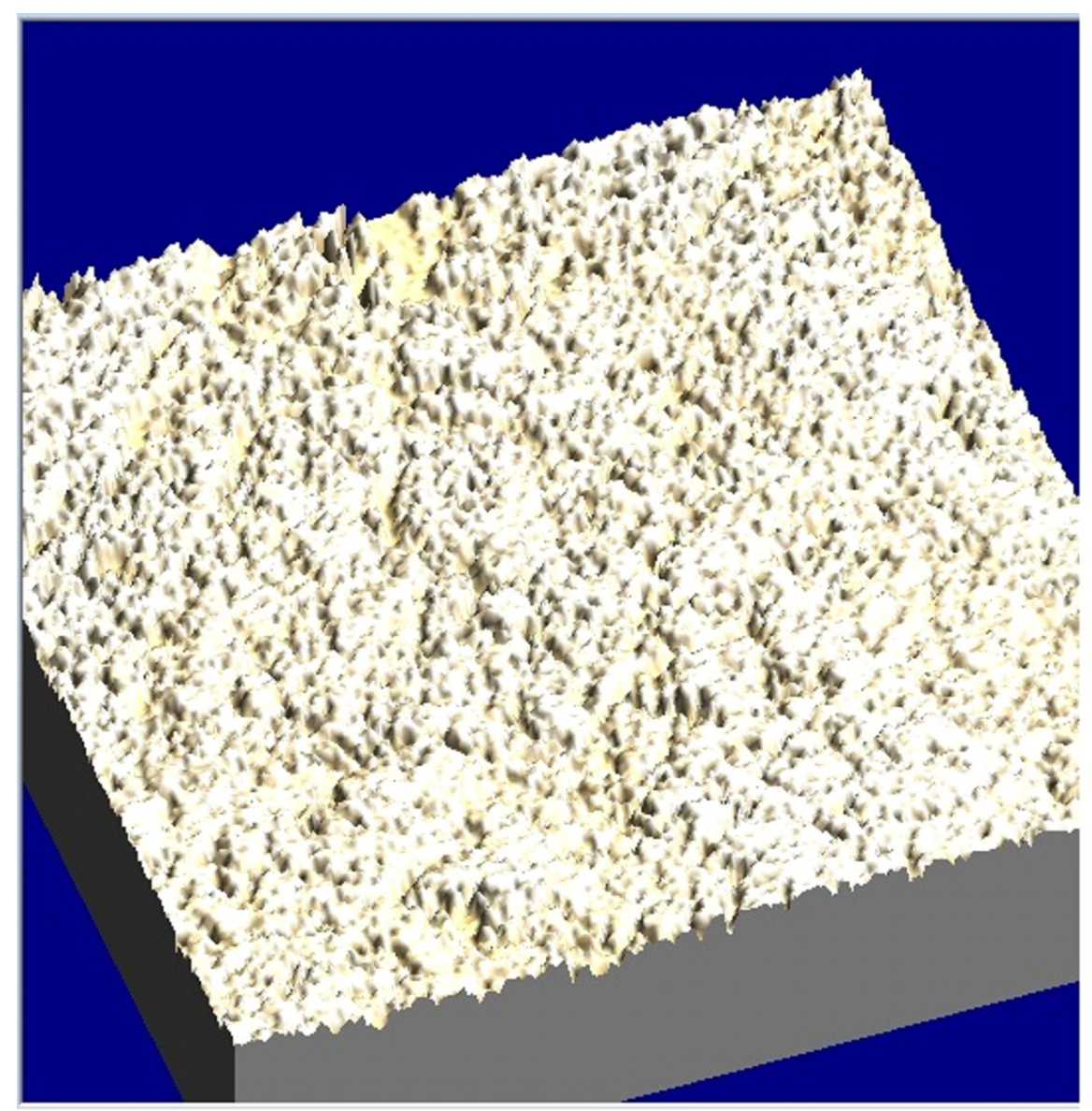

Fig. 29. Topografía de superficie anodizada.

Los tratamientos de superficie se realizaron en Kinetical SRL Biounite, empresa certificada ISO9001 e ISO13485 otorgada por DNV (det norske veritas) (http://implantesbiounite.com.ar/).

- $\quad$ Análisis de superficie topográfica

La superficie topográfica de las placas de titanio a nivel nanométrico fueron caracterizadas utilizando una técnica no invasiva que es la Microscopía de Fuerza Atómica (AUTO PROBE, PARK SCIENTIFIC INSTRUMENTS, USA) para evaluar los cambios superficiales y la rugosidad (tamaño del escaneo: $2 \times 2 \mu \mathrm{m}^{2}$ y $500 \times 500 \mathrm{~nm}^{2}$ ). 
Estos análisis se realizaron en el Centro de Microscopías Avanzadas de la Facultad de Ciencias Exactas y Naturales-UBA (IFIBACONICET-UBA). El equipo es coordinado por Dra. Lía I. Pietrasanta.

- Procesamiento de imágenes topográficas

Las 18 imágenes obtenidas por los barridos del microscopio de fuera atómica fueron calibradas y analizadas con el programa WSxM3.1 (Windows Scanning X -Force, Tunneling, Near Optical- Microscope [54]).

A cada imagen se la calibro, se decidió unidad de medición en este caso nanómetro $(\mathrm{nm})$ y se realizó un análisis de rugosidad que consistió en la medición de los siguientes parámetros: RSM rugosidad, Altura promedio, Altura mínima y Altura máxima.

En la Tabla IV se presenta información detallada obtenida del procesamiento de las imágenes del Microscopio de Fuerza Atómica. 
Tabla IV: Información pormenorizada de cada una de las imágenes tratadas. Los nombres de las imágenes se corresponden con las imágenes del anexo electrónico.

\begin{tabular}{|l|l|l|l|l|l|r|r|}
\hline $\begin{array}{l}\text { Tratamiento } \\
\text { de } \\
\text { superficie }\end{array}$ & $\begin{array}{l}\text { Nombre de la } \\
\text { imagen }\end{array}$ & $\begin{array}{l}\text { Escala } \\
\text { de } \\
\text { imagen }\end{array}$ & $\begin{array}{l}\text { Superficie } \\
\text { escaneada }\end{array}$ & $\begin{array}{l}\text { RMS } \\
\text { Rugosidad } \\
\text { (nm) }\end{array}$ & $\begin{array}{l}\text { Altura } \\
\text { promedio } \\
\text { (nm) }\end{array}$ & $\begin{array}{l}\text { Altura } \\
\text { mínima }\end{array}$ & $\begin{array}{l}\text { Altura } \\
\text { máxima(nm) }\end{array}$ \\
\hline Anodizadas & anodizadoa.01 & 1.0 um & $5 \times 5$ um & 179.5574003 & 728.2853445 & 0 & 1483.031358 \\
\hline Anodizadas & anodizado.02 & $\begin{array}{l}400 \\
\mathrm{~nm}\end{array}$ & $2 \times 2$ um & 234.6929679 & 686.3712354 & 0 & 1470.037448 \\
\hline Anodizadas & anodizado.03 & 1.0 um & $5 \times 5$ um & 535.2864995 & 1593.819889 & 0 & 2490.587732 \\
\hline Anodizadas & anodizadob.04 & 1.0 um & $5 \times 5$ um & 247.9996038 & 1696.474138 & 0 & 2386.72826 \\
\hline Anodizadas & anodizadob.05 & 1.0 um & $5 \times 5$ um & 289.6602856 & 913.7332378 & 0 & 1881.18904 \\
\hline Anodizadas & anodizadoc.06 & 1.0 um & $5 \times 5$ um & 372.1345289 & 977.8200883 & 0 & 1964.928363 \\
\hline Lisas & corte.01 & $\begin{array}{l}400 \\
\mathrm{~nm}\end{array}$ & $2 \times 2$ um & 20.04985635 & 48.68423811 & 0 & 126.2176882 \\
\hline Lisas & corte.02 & 1.0 um & $5 \times 5$ um & 42.60154825 & 148.4712817 & 0 & 415.0307168 \\
\hline Lisas & corteb.03 & 1.0 um & $5 \times 5$ um & 69.81248445 & 296.8727075 & 0 & 650.3597015 \\
\hline Lisas & corteb.04 & $\begin{array}{l}400 \\
\mathrm{~nm}\end{array}$ & $2 \times 2$ um & 20.54652504 & 126.4894865 & 0 & 260.4838649 \\
\hline Lisas & cortec.05 & $\begin{array}{l}400 \\
\mathrm{~nm}\end{array}$ & $2 \times 2$ um & 26.10853138 & 64.1087626 & 0 & 382.9607279 \\
\hline Lisas & corteb.06 & 1.0 um & $5 \times 5$ um & 83.84399996 & 205.890536 & 0 & 1541.551845 \\
\hline $\begin{array}{l}\text { Ácido } \\
\text { Grabadas }\end{array}$ & grabacido.00 & 1.0 um & $5 \times 5$ um & 277.0843093 & 646.0480023 & 0 & 1382.956203 \\
\hline $\begin{array}{l}\text { Ácido } \\
\text { Grabadas }\end{array}$ & grabado.01 & $\begin{array}{l}400 \\
\mathrm{~nm}\end{array}$ & $2 \times 2$ um & 50.65435558 & 131.0996202 & 0 & 265.1155042 \\
\hline $\begin{array}{l}\text { Ácido } \\
\text { Grabadas }\end{array}$ & grabado.02 & $\begin{array}{l}400 \\
\mathrm{~nm}\end{array}$ & $2 \times 2$ um & 129.9681657 & 400.0562495 & 0 & 768.5064762 \\
\hline $\begin{array}{l}\text { Ácido } \\
\text { Grabadas }\end{array}$ & grabado.03 & $1.0 \mathrm{um}$ & $5 \times 5$ um & 103.5086161 & 303.8389165 & 0 & 844.5387322 \\
\hline $\begin{array}{l}\text { Ácido } \\
\text { Grabadas }\end{array}$ & grabadob.04 & $\begin{array}{l}400 \\
\mathrm{~nm}\end{array}$ & $2 \times 2$ um & 93.49603626 & 199.0111416 & 0 & 451.3723678 \\
\hline $\begin{array}{l}\text { Ácido } \\
\text { Grabadas }\end{array}$ & grabadob.05 & 1.0 um & $5 \times 5$ um & 224.1110714 & 458.9781993 & 0 & 1195.099709 \\
\hline
\end{tabular}




\section{- $\quad$ Análisis estadístico de los datos}

Las variables fueron evaluadas con estadística descriptiva como medias, varianzas, desvíos estándar y coeficiente de variación. Para determinar si las variables en el estudio presentaban distribución normal se realizó la prueba de Shapiro-Wilks modificado. Las variables RMS Rugosidad como las Altura máxima presentaron un comportamiento de distribución normal $\left(W_{\text {RMS Rugosidad }}=0,88 ; n=18 p=0,05 ; W_{\text {Máxima Altura }}=0,89\right.$; $\mathrm{n}=18 \mathrm{p}=0,10$ ), salvo Altura promedio donde no se detectó normalidad (WAltura promedio $=0,89 ; n=18 p=0,10$ ). Se utilizó una prueba de distribución libre para inferencia basada en más de dos muestras de Kruskal Wallis (Análisis de varianza no paramétrica) con la finalidad de determinar si hay diferencias significativas del tratamiento de superficies (Lisas, anodizadas y grabado acido) en Altura promedio. Para las variables de distribución normal (RMS Rugosidad y en Altura máxima) se utilizó ANOVA (Análisis de la varianza paramétrica) con la finalidad de determinar si hay diferencias significativas del tratamiento de superficies (Lisas, anodizadas y grabado acido). Como pruebas a posteriori se trabajo con Tukey HSD.

Para la realización de las pruebas estadísticas se trabajó con el programa Statistical versión 7.0 y se consultó a Sokal y Rohlf [55] de estadística paramétrica y Siegel [56] de estadística no paramétrica. El nivel de significación para todas las pruebas estadísticas realizadas fue de $\alpha=0,05$. 


\section{- Capítulo 6: Resultados}

Los valores de RMS Rugosidad, Altura promedio y Altura máxima fueron altamente variables según el tratamiento (Tabla V).

Tabla V: Se presenta la estadística descriptiva para los valores de RMS Rugosidad Altura promedio, Altura mínima y Altura máxima discriminados por tratamiento de superficie.

\begin{tabular}{|l|l|r|r|r|r|r|r|}
\hline Variable & Tratamiento & N & \multicolumn{1}{l|}{ Media } & \multicolumn{1}{l|}{$\begin{array}{l}\text { Valor } \\
\text { Mínimo }\end{array}$} & \multicolumn{1}{l}{$\begin{array}{l}\text { Valor } \\
\text { Máximo }\end{array}$} & $\begin{array}{l}\text { Desv. } \\
\text { Estandar }\end{array}$ & Coef. Var. \\
\hline $\begin{array}{l}\text { RMS } \\
\text { Rugosidad }\end{array}$ & $\begin{array}{l}\text { Ácido } \\
\text { grabadas }\end{array}$ & 6 & 146.4704 & 50.6544 & 277.084 & 86.2474 & 58.88386 \\
\hline $\begin{array}{l}\text { Altura } \\
\text { promedio }\end{array}$ & $\begin{array}{l}\text { Ácido } \\
\text { grabadas }\end{array}$ & 6 & 356.5054 & 131.0996 & 646.048 & 186.8787 & 52.41960 \\
\hline Altura mínima & $\begin{array}{l}\text { Ácido } \\
\text { grabadas }\end{array}$ & 6 & 0.0000 & 0.0000 & 0.000 & 0.0000 & 0.00000 \\
\hline Altura máxima & $\begin{array}{l}\text { Ácido } \\
\text { grabadas }\end{array}$ & 6 & 817.9315 & 265.1155 & 1382.956 & 425.3541 & 52.00364 \\
\hline $\begin{array}{l}\text { RMS } \\
\text { Rugosidad }\end{array}$ & Lisas & 6 & 43.8272 & 20.0499 & 83.844 & 27.2007 & 62.06352 \\
\hline $\begin{array}{l}\text { Altura } \\
\text { promedio }\end{array}$ & Lisas & 6 & 148.4195 & 48.6842 & 296.873 & 92.6041 & 62.39351 \\
\hline Altura mínima & Lisas & 6 & 0.0000 & 0.0000 & 0.000 & 0.0000 & 0.00000 \\
\hline Altura máxima & Lisas & 6 & 562.7674 & 126.2177 & 1541.552 & 510.2546 & 90.66883 \\
\hline $\begin{array}{l}\text { RMS } \\
\text { Rugosidad }\end{array}$ & Anodizadas & 6 & 309.889 & 179.557 & 535.286 & 127.7175 & 41.21401 \\
\hline $\begin{array}{l}\text { Altura } \\
\text { promedio }\end{array}$ & Anodizadas & 6 & 1099.417 & 686.371 & 1696.474 & 437.8404 & 39.82477 \\
\hline Altura mínima & Anodizadas & 6 & 0.000 & 0.000 & 0.000 & 0.0000 & 0.00000 \\
\hline Altura máxima & Anodizadas & 6 & 1946.084 & 1470.037 & 2490.588 & 432.7254 & 22.23570 \\
\hline
\end{tabular}


El RMS Rugosidad es estadísticamente mayor en las superficies de titanio anodizadas (ANOVA, $F_{(2,15)}=61,29 n=18, p=0,000001$, Tukey HSD Figura 30).

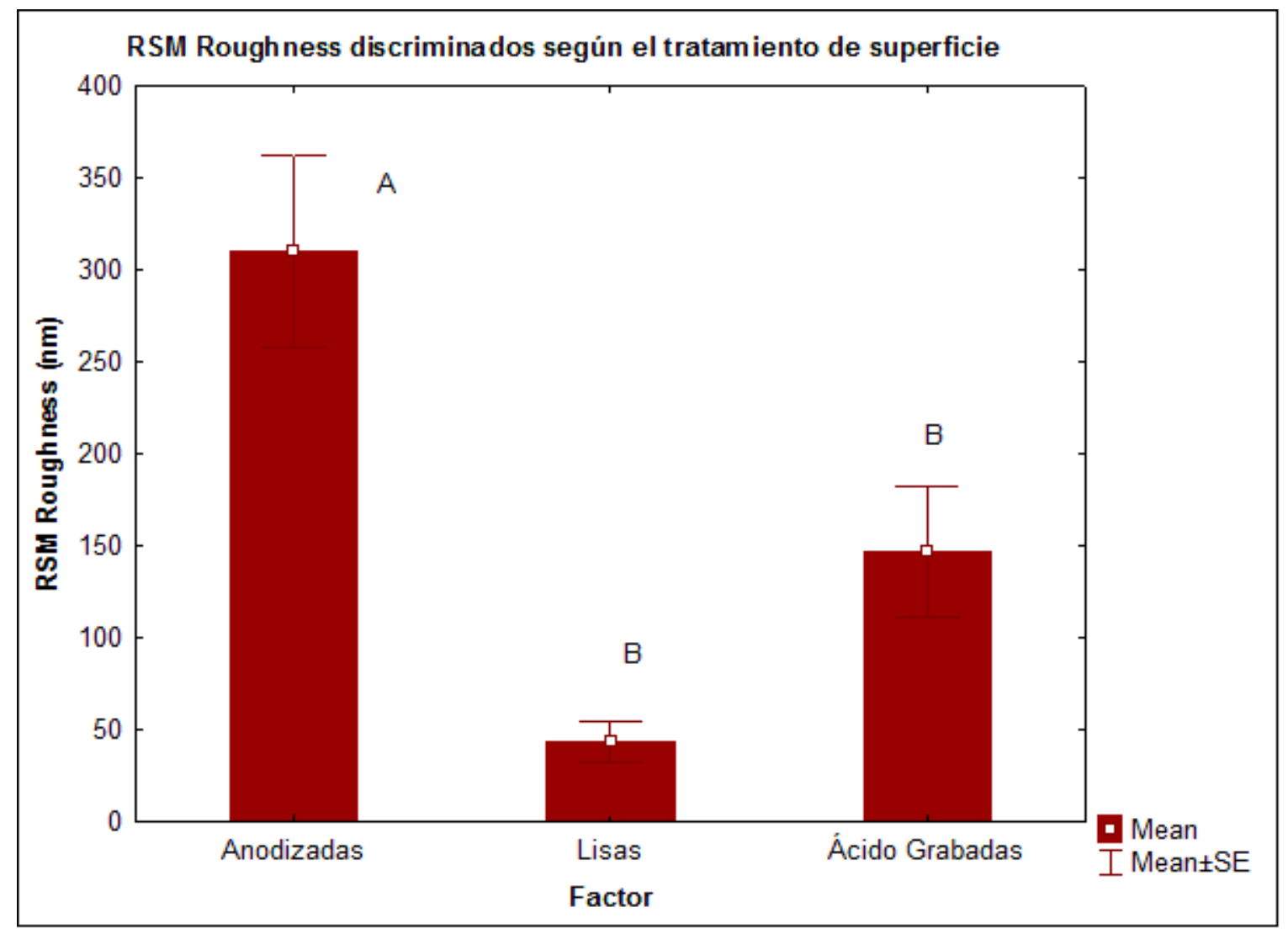

Figura 30: comportamiento de RSM Rugosidad (Roughness) discriminado según el tratamiento de superficie, los bigotes indican el desvío estándar y las cajas los valores medios. Letras diferentes indican diferencias estadísticas significativas con $\alpha=0,05$ 
Las superficies anodizadas presentaron valores de Altura promedio (Averange Height) significativamente mayores (Kruscal Wallis, $\mathrm{H}=$ 13,05, $n=18, P=0,0013$; figura 31).

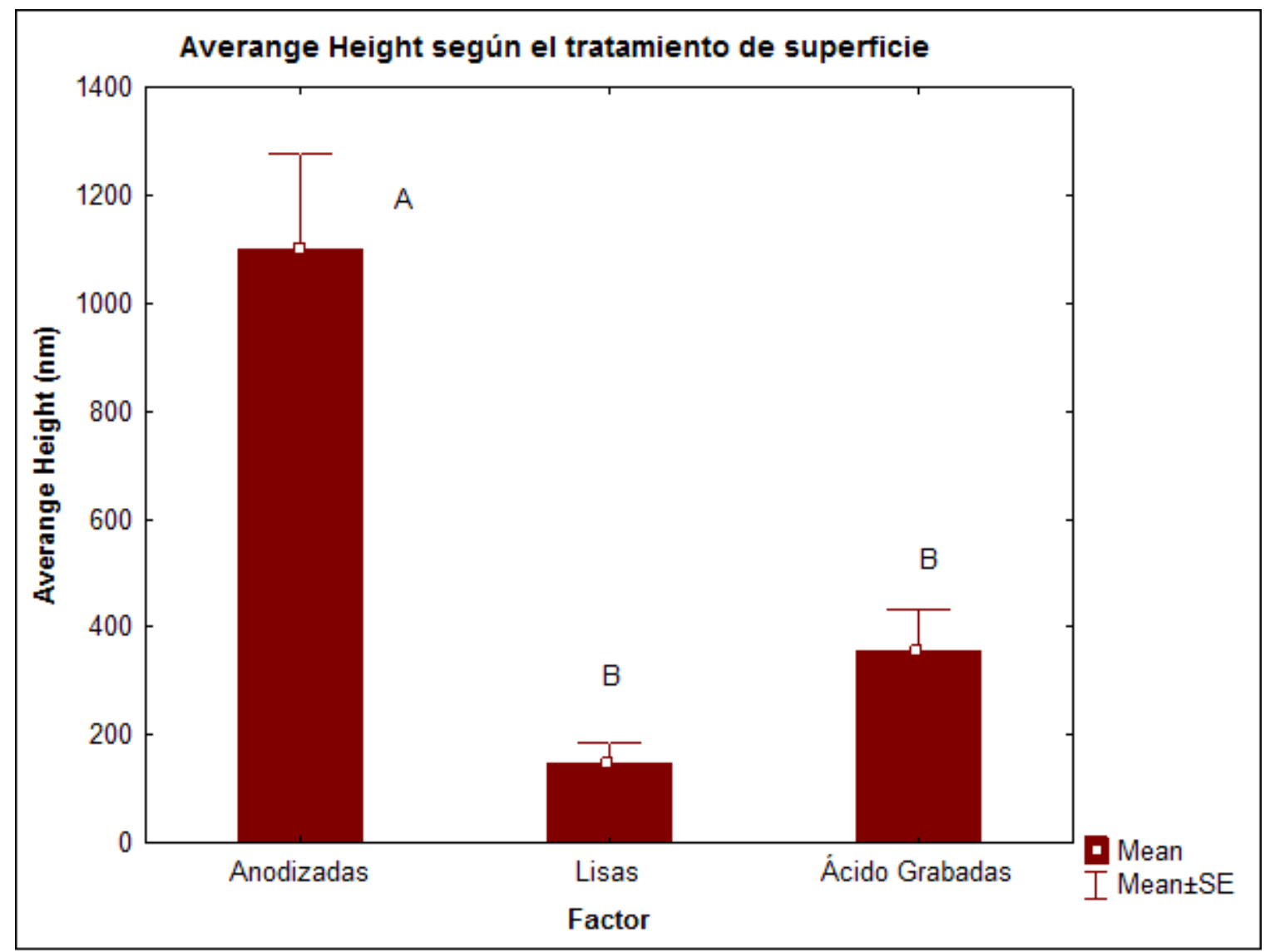

Figura 31: comportamiento de Averange Height discriminado según el tratamiento de superficie, los bigotes indican el desvío estándar y las cajas los valores medios. Letras diferentes indican diferencias estadísticas significativas con $\alpha=0,05$ 
Las superficies anodizadas presentaron valores de Altura máxima (Maximun height) significativamente mayores que el resto de las superficies lisas y ácido grabadas (ANOVA, $F_{(2,15)}=15,52, n=18, p=$ 0,0002, Tukey HSD Figura 32).

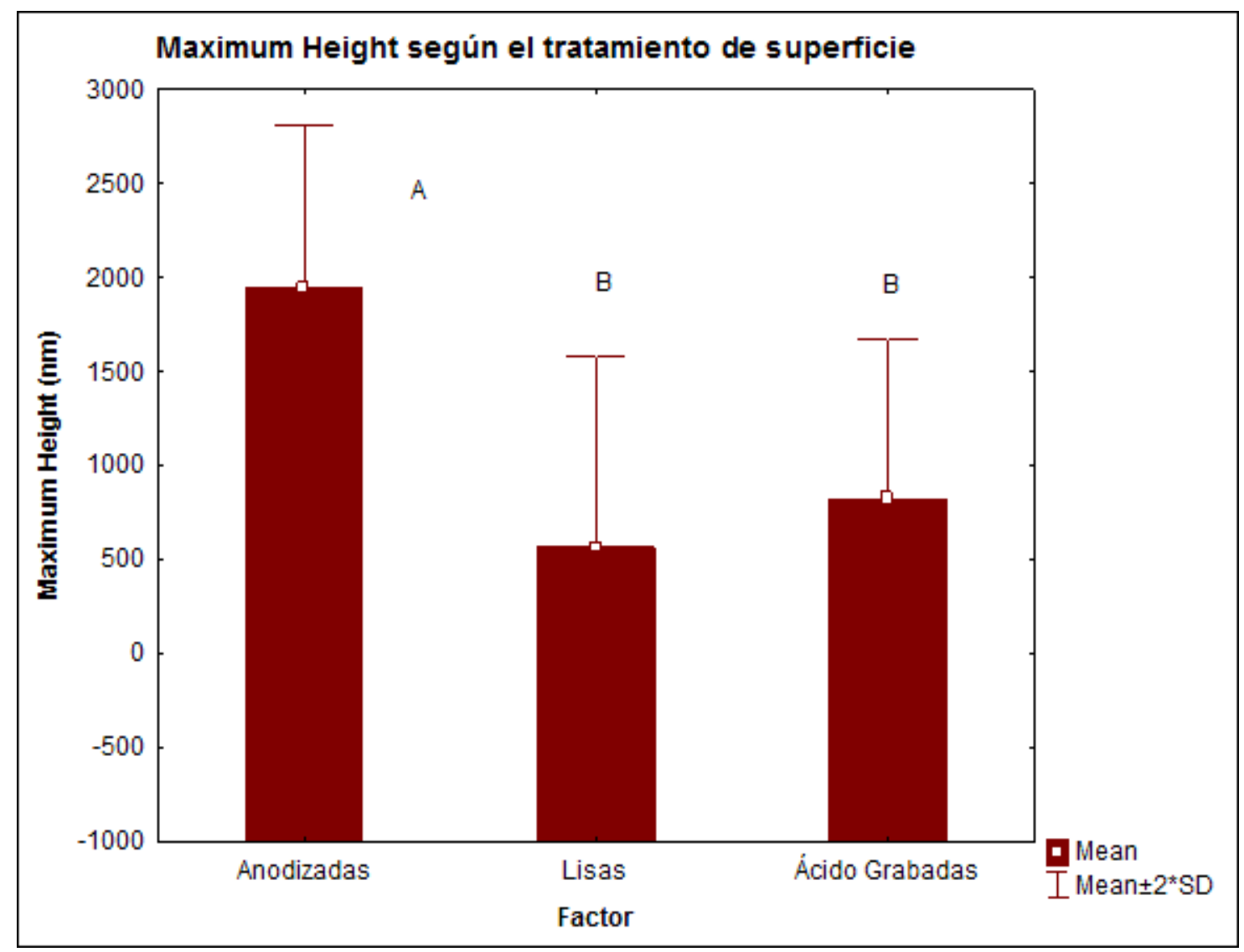

Figura 32: comportamiento de Maximun Height discriminado según el tratamiento de superficie, los bigotes indican el desvío estándar y las cajas los valores medios. Letras diferentes indican diferencias estadísticas significativas $\operatorname{con} \alpha=0,05$ 


\section{- Capítulo 7: Conclusiones}

Los implantes dentales son, en la actualidad, el método más efectivo para la rehabilitación de pacientes parcial o totalmente edéntulos. Consisten en la aplicación, mediante procedimientos quirúrgicos, de un material aloplástico que funciona como cimiento de una prótesis dental. El material más empleado para dicho fin es el titanio, pues sus propiedades bioinertes y biocompatibles tienden a disminuir las posibles complicaciones implicadas en una intervención de este tipo.

Existen diversos tipos de implantes dentales. Actualmente se considera que los que mejores resultados tienen son los implantes endoóseos. Éstos, si son aplicados de manera correcta, suelen integrarse rápidamente al hueso, garantizando su durabilidad. Dicho proceso se denomina oseointegración.

Muchos estudios recientes han investigado la relación entre la osteointegración y la superficie de los implantes, concluyendo que la rugosidad de las superficies contribuye de manera positiva al proceso en cuestión, garantizando gran parte del éxito del implante. Esto sucede por una serie de procesos que se dan a nivel celular e involucran la regeneración del tejido óseo. El proceso natural de cicatrización y regeneración del hueso se realiza estando o no presente el cuerpo de titanio del implante. Por ello es preciso considerar que la calidad de la superficie de dicho cuerpo no influye de manera decisiva en dicho proceso. Sin embargo, se ha comprobado que el hueso de adhiere de forma más rápida y efectiva en superficies rugosas, pues la superficie de contacto es mayor en estas superficies que en las lisas. 
Respecto a la calidad topográfica de las superficies, es preciso indicar que, al darse los procesos en cuestión a nivel celular, la escala para mensurar la rugosidad implicada es una escala de carácter nanométrico. No interesa, pues, la rugosidad macroscópica de la superficie del titanio, sino la nanorugosidad.

Ésta es lograda a partir de una serie de tratamientos aplicados a las superficies llamadas lisas, que a nivel nanométrico no son en verdad lisas. En el presente trabajo se expuso una experiencia de laboratorio, mediante la cual se analizaron tres tipos de superficies de implantes dentales de titanio. El primer tipo (superficies lisas) no recibió ningún tratamiento. Los otros dos, sí: la superficie con grabado ácido y la superficie anodizada, que recibieron tratamientos por sustracción y por adición respectivamente.

Para dar cuenta del tipo de rugosidad y así efectuar el análisis comparativo, se ha empleado un microscopio de fuerzas atómicas (AFM), capaz de medir la rugosidad en una escala nanométrica. El análisis en cuestión ha revelado la mayor presencia de rugosidad en superficies anodizadas que en ácido grabadas. De más está decir, tal como era de esperar, que las superficies lisas o no tratadas presentan el menor grado de rugosidad.

La RMS Rugosidad presenta una diferencia de aproximadamente $150 \mathrm{~nm}$ entre las superficies ácido grabadas y las anodizadas. Las superficies anodizadas presentan, por tanto, prácticamente el doble de RSM Rugosidad que las ácido grabadas. Asimismo, la RSM Rugosidad de las superficies lisas abarca tan sólo $1 / 6$ de la que se ha podido medir en las superficies anodizadas. Asimismo, la altura promedio de las superficies anodizadas es casi diez veces mayor que la presente en las superficies lisas y tres veces mayor respecto a las grabadas con ácido. 
La caracterización nanométrica dada por los resultados del estudio realizado para el presente trabajo, abre paso a una nueva hipótesis, susceptible de ser corroborada por ulteriores experiencias clínicas, según la cual, gracias a su alta rugosidad, las superficies anodizadas serían convenientes frente a las lisas y las ácido grabadas en pos de lograr una osteointegración altamente efectiva. Asimismo, cabe destacar que la espesa capa de óxido presente en las superficies anodizadas operaría, además, como protectora del material del implante, evitando la ionización de la misma. 


\section{$\underline{\text { Referencias bibliográficas }}$}

- 1- Sykaras N, lacopino AM, Marker VA, Triplett RG, Woody RD. Implant materials, designs, and surface topographies: their effect on osseointegration. A literature review. Int J Oral Maxillofac Implants. 2000; 15 (5): 675-90.

- 2- Albrektsson T, Wennerberg A. The impact of oral implants - past and future, 1966-2042. J Can Dent Assoc. 2005; 71 (5): 327.

- 3-Pigatto C, Antonini LM, Schneider EL, Malfatti CF. Superficies Nanoestructuradas de la Aleación Ti6Al4V. Influencia del Tiempo de Electropulido. Información Tecnológica. 2013; 23 (5): 13-22.

- 4- Jokstad A. Oral implants--the future. Aust Dent J. 2008; $53 \mathrm{Suppl}$ 1: S89-93.

- 5- Elias CN, Meirelles L. Improving osseointegration of dental implants. Expert Rev Med Devices. 2010; 7 (2): 241-56.

- 6- Anil S, Anand PS, Alghamdi H, Jansen JA. Dental Implant Surface Enhancement and Osseointegration. En Turkyilmaz I (Ed.). Implant Dentistry - A Rapidly Evolving Practice. In Tech. DOI: 10.5772/16475. 2011. Disponible en http://www.intechopen.com/books/implant-dentistry-a-rapidlyevolving-practice/dental-implant-surface-enhancement-andosseointegration

- 7- Arismendi J, Agudelo L, Ospina A. Implantes de superficie lisa o rugosa: Una decisión clínica. Revista Internacional de Prótesis Estomatológica. Ed. Hispanoamericana. 2004; 6 (1): 9-15.

- 8- Zareidoost A, Yousefpour M, Ghaseme B, Amanzadeh A. The relationship of surface roughness and cell response of chemical surface modification of titanium. J Mater Sci Mater Med. 2012; 23 (6): 1479-88. 
- 9- Leyva AG. Síntesis y caracterización de nano-estructuras de óxidos de metales de transición. Tesis para optar al título de Doctor en Ciencia y Tecnología, Mención Física. Universidad Nacional de General San Martín. Comisión Nacional de Energía Atómica. Instituto de Tecnología Prof. Jorge A. Sábato. Buenos Aires, 2007.

- 10- Cabrera Aguilar R. Obtención y caracterización de recubrimientos de Sialon mediante RF Sputtering. Tesis para obtener el título de Ingeniero en Ciencias de los Materiales. Universidad Autónoma del Estado de Hidalgo, Instituto de Ciencias Básicas e Ingeniería. Area Académica de Materiales y Metalurgia. Pachuca, 2007.

- 11- Sharma S, Cross SE, Hsueh C, Wali RP, Stieg AZ, Gimzewski JK. Nanocharacterization in dentistry. Int J Mol Sci. 2010; 11 (6): 2523-45.

- 12- Schroeder, A., Sutter F. y Gisbert, K. Implantología oral. El sistema ITI. Editorial Médica Panamericana, Madrid, 1993.

- 13- Esposito, M., Hisrsch, J. M., Leckholm, U, Thomsen, P. Biological factors contributing to failures of osseointegrated oral implants. (II) Etiphatogenesis. Eur J Oral Sci 106. 1998; 721-764.

- 14- Buser, D., Merickse-Stern R., Bernarrd, J. P., Behneke, N., Hirt, H. P. Belser, U.C, Lang, N. P. Long-term evaluation of nonsubmerged ITI implants. Part 1: 8-year table analysis of prospective multi-center study with 2359 implants. Clin Oral Implants Res 8. $1997 ; 161-172$.

- 15- Bernard, B. Calcium metabolism and bone mineralization. En: "Bone Metabolism and Mineralization. Vol 4". Hall B. CRC Press, Boca Ratón, 1992.

- 16- Hill, P. Bone remidelling. Br. J. Orthod 25. 1998; 101-107. 
- 17- Erikson A. R. Heat-induced tissue injury. An in vivo investigation of heat tolerance of bone and temperature rise in drilling coartical bone. Tesis doctoral. Dep. Pf Anatomy, Un. Of Götelborg, Götelborg, 1984.

- 18- Predecki, P. Auslender, B., Stepha, J. E., Mooney, V., Stanstli, C. Attachment of bone to threaded implants by ingrowth and mechanical interlocking. J Biomed Mater Res 6. 1972; 401-412.

- 19-Weiss, C. M. A cormparative analysis of fibro-osteal integration and other variables that affect long term bone maitenence around dental implants. J Oral Implantol 13. 1989; 467-487-

- 20- Misch, C.E. "Implantología contemporánea". Mosby/Doyma Libros, Madrid, 1995.

- 21- Schroeder, A., van der Zypen E., Stich, H., Sutter, F. The reactions of the bone, consecutive tissue and epithelium to endosteal implants with titanium-spryed surfaces. J Maxillofac Surg 9. $1981 ; 15-25$.

- 22- Albrektsson, T. Bränermark P. I., Hansson, H. A., Lindström J. Osseointegrsted titanium implants. Acta Orthop Scand 52. 1981; 155-170.

- 23- Breme, J., Biehl, V. Metallic biomatirials. En: Handbook of Biomaterial Propieties. Chapman and Hall, Londres, 1998.

- 24- Wlliams, D. F. (ed.) Definition of biomaterials: Proceeding of Consensus Conference of the European Society for Biomaterials. Progress in Biomedical Engineering, Elsvier, Amsterdam, 1987.

- 25- Bruscki, J. B. Biomechanical factors affecting the Bone-dental Implant Interface. Clinical Master 10. 1992; 153-201.

- 26- Kasemo, B. Lausumaa, J. Surface Science Aspects on Inorganic Biomaterials. CRC Crit Rev Biocompat 2. 1986; 335-380. 
- 27- Vörös, J., Wieland M., Ruiz-Taylor, L., Textor, M., Brunette, D. M. Characterization of Tutanium Surfaces. En: Titanium in Medicine: Material Science, Surface Science, Engineering, Biological Responses and Medical Applications. Springer Verlag, Berlin. 2001; 87-144.

- 28- Brunette, D. M., Tengvall, P., Textor, M., Thomasen, P. (eds.). Titaniumin Medicine. Springer Verlag, Berlin, 2001.

- 29- Schrenk, R. K., Buser, D., Osseointegration: a Reality. Periodontology 2000 17. 1998; 22-35.

- 30- Cohran, D. L., Schenk, R. K., Lussi, A., Higginbottom F. L., Buser D. Bone Response to Unloaded and Lodaded Titanium Implants with a Sansblasted and Acid-etched Surface: a Histometric Study in the Canine Mandible. J Biomed Mater Res 40. 1998; 1-11.

- 31- Hansson, A., Johnsson, K., Jacobsson, M., Turesson, I. Removal Torniques for Titanium Implants Following Irradiation. En: Tissue Integration in Oral, Orthopedic and Maxillofacial Reconstruction. Preoceedings of Second International Congress on Tissue Integration in Oral, Orthopedic and Maxillofacial Reconstruction. Mayo 1990; 228-233.

- 32- Balshi, T. J., Wolfinger, G. J., Balshi S. F. Analysis of 356 Pterygomaxillary Implants in Edentulous Aches for Fixed Prothesis Anchorage. Int J Oral Maxillofac Implants 14. 1999; 398-406.

- 33- Brunski J. B. Biomechanical Factors Affecting the Bone-dental implant interface. Clinical Mater 10. 1992; 153-201.

- 34- Friberg, B. Sterile Operating Conditions for the Placement of Intraoral Implants. J Oral Maxillofac Surg 54. 1996; 1334-1336.

- 35- Fiorellini, J. P., Engerbreston, S. P., Donath, K., Weber, H. P. Guided Bone Regeneration Utilizing Expanded Polytetrafluoroethylene Membranes in Combination with Submerged and Nonsubmerged dental Implants in Beagle Dogs. J Periodontol 69. $1998 ; 528-535$. 
- 36- Radow, K., Ericsson, I, Nilner, K. Petersson A. Glantz P. O. Immediate functional Loading of Bränemark Dental Implants. An 18month Clinical Follow-up Study. Clon Oral Implants Res 10. 1999; 8-15.

- 37- Bränemark P. I., Breine, U., Johansson B., Roylance, P. J., Röckert, H., Yoffey, J. M. Refeneration of Bona Marrow. Acta Anat 59. 1964; 1-46.

- 38- Bagno, A., di Bello, C. Surface Treatment and Roughness Propierties of Ti-based Biomaterials. J Master Sci: Master Med 15. 2004; 935-949.

- 39- Boyan, D., Belser, U. C., Lang, N. P. The Original One.stage Dental Implant System and its Clinical Applications. Periodontology 200017 (1998) 106-118.

- 40- Wennberg, A. On Surface Roughness and Implant Incorporation. Tesis doctoral, Un. Göteborg, Göteborg, 1996.

- 41- Boyan, D., Dean, D., Lohmann, Ch. Cohren, D., Sylvia, V. L., Schwatz, Z. The Titanium Bone-Cell Interface iln Vitro: The Role of the Surface in Promoting Osseointegration. En: Titanium in Medicine: Material Science, Surface Science, Engineering, Biological Responses and Medical Applications. Springer Verlag, Berlin. 2001; 561-586.

- 42- Von Recum, A. F. New Aspects of Biocopatibility. Motion at the Interface. En: Clinical Implant Materials. Elseiver, Amsterdam, 1990.

- 43- Buser, D. Nydegger, T., Hirt, H. P., Cochran D. L. Schenk, R. K. Hirt, H. P., Snétivy, D., Nolte L. P. Influence of Surface Characteristics on the Interface Shear Strength Between Titanium Implants and Bona. A Biomechanical Study in the Maxilla of Miniature Pigs. J Biomed Master Res 45. 1999; 75-83.

- 44- Von Recum, A. F., Surface Characterization of Microtextured Silicone. Biomaterials 13. 1992; 665-687. 
- 45- Thomas, T. R. Rough Surfaces. Longman Press, Londres-N. Y., 1982.

- 46- Benett, J. M, Mattsson, L. Introduction to Surface Roughness and Scattering. Optical Society of America, Washington D. C., 1989.

- 47- Fernández Boredau, E., Bassone, L. Naldini, P. Tratamientos de superficie de implantes. RAOA 5 vol. 97. 2009; 423-429.

- 48- Wennerberg A, Albrektsson T, Lausmaa J. Torque and Histomorphometric Evaluation of c.p. Titanium Screws Blasted with 25- and 75-microns-sized Particles of Al2O3. J Biomed Mater Res 30. 1996; 251-60

- 49- Ivanoff CJ,Widmark G, Johansson C, Wennerberg A. Histologic Evaluation of Bone Response to Oxidized and Turned Titaniummicro-implants in Human Jawbone. Int $\mathrm{J}$ Oral Maxillofac Implants 18. 2003; 341-8

- 50- Miranda Burgos P, Rasmusson L, Meirelles L, Sennerby L. Early bone tissue responses to turned and oxidized implants in the rabbit tibia. Clin Implant Dent Relat Res 10 vol 3. 2008; 181-90.

- 51- Hinojosa Rivera, M., Reyes Melo, M. La rugosidad de superficies: Topometría. Ingenierías, vol. IV, 11. 2001; 27-33.

- 52- Hermans, Z. R. Diseño y construcción de un microscopio de fuerza atómica versátil. Tesis de licenciatura en ciencias exactas. PUCC, 2001.

- 53- Worcester, D. L., Miller, R. G., P.J. Bryant, J. Atomic force microscopy of purple membranes", J. Microsc, 152 vol. 3 (1988).

- 54- Horcas, I., Fernández, R., Gómez-Rodríguez, J., Colchero, J., Gómez-Herrero, J., Baro, A. WSXM: A software for scanning probe microscopy and a tool for nanotechnology. Review of Scientific Instruments 78 (2007) 013705 
- 55- Sokal, R.R., Rohlf, F. J. Introducción A La Bioestadística. Editorial Reverté, 1999.

- 56- Siegel, S. Estadística No Paramétrica. Editorial Trillas. 1980.

Od. Alejandro Costantino

Autor
Prof. Dra. M. Cecilia Cortizo

Directora 